TABLE OF CONTENTS

$\underline{\text { Page }}$

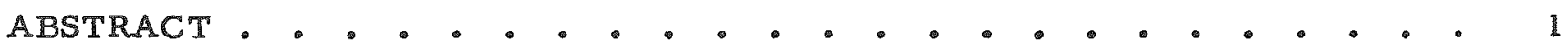

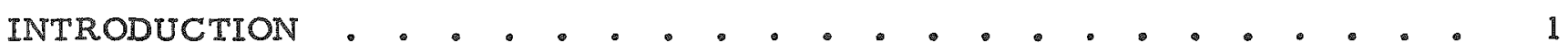

PROPERTIES OF NUCLEAR CARBIDES . . . . . . . . . . . . . . . 3

URANIUM, THORIUM, AND PLUTONIUM CARBIDE SYSTEMS • • • . . $\quad 11$

INTRODUCTION $\cdot \cdot \cdot \cdot \cdot \cdot \cdot \cdot \cdot \cdot \cdot \cdot \cdot \cdot \cdot \cdot \cdot \cdot \cdot \cdot \cdot \cdot \cdot \cdot \cdot \cdot \cdot 11$

THE URANIUM-CARBON BINARY SYSTEM $\cdot \cdot \cdot \cdot \cdot \cdot \cdot \cdot \cdot \cdot \cdot \cdot \cdot$.

URANIUM-CARBON TERNARY SYSTEMS . . . . . . . . . . . . 15

THE THORIUM-CARBON BINARY SYSTEM . . . . . . . . . . . 40

THORIUM-CARBON TERNARY SYSTEMS $. \cdot . \cdot . \cdot . \cdot . \cdot . \cdot . \quad .42$

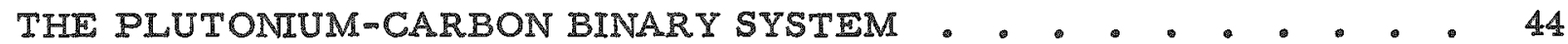

PLUTONIUM-CARBON TERNARY SYSTEMS . . . . . . . . . . . 46

QUATERNARY SYSTEMS . . . . . . . . . . . . . . . . . 47

COMPATIBILITY AND CORROSION BEHAVIOR OF NUCLEAR CARBIDES • . . 49

PREPARATION AND FABRICATION OF NUCLEAR CARBIDES . . . . . . . 58

THERMODYNAMICS . . . . . . . . . . . . . . . . . 58

PREPARATION BY CHEMICAI REACTIONS . . . . . . . . . . . 64

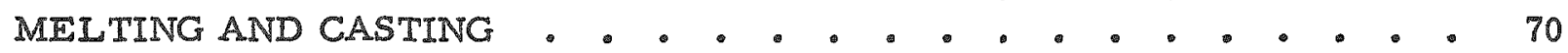

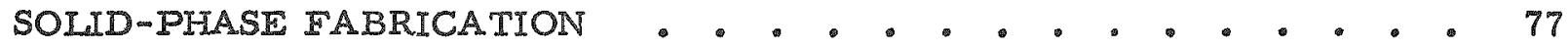

STORAGE AND HANDLING . . . . . . . . . . . . . . . . 89

EFFECTS OF IRRADIATION UPON URANIUM CARBIDE . . . . . . . . . 92 


\section{DISCLAIMER}

This report was prepared as an account of work sponsored by an agency of the United States Government. Neither the United States Government nor any agency Thereof, nor any of their employees, makes any warranty, express or implied, or assumes any legal liability or responsibility for the accuracy, completeness, or usefulness of any information, apparatus, product, or process disclosed, or represents that its use would not infringe privately owned rights. Reference herein to any specific commercial product, process, or service by trade name, trademark, manufacturer, or otherwise does not necessarily constitute or imply its endorsement, recommendation, or favoring by the United States Government or any agency thereof. The views and opinions of authors expressed herein do not necessarily state or reflect those of the United States Government or any agency thereof. 


\section{DISCLAIMER}

Portions of this document may be illegible in electronic image products. Images are produced from the best available original document. 


\title{
AN EVALUATION OF DATA ON NUCLEAR CARBIDES
}

\author{
Frank A. Rough and Walston Chubb
}

\begin{abstract}
Available data on the physical and mechanical properties, constitution, compatibility, and radiation behavior and on fabrication methods for uranium, thorium, and plutonium carbides were reviewed. Very incomplete data on thorium and plutoninm carbides were located.
\end{abstract}

Only limited daia on the physical and mechanical properties of uranium carbides were discovered. No information on high-temperature mechanical properties uas found. Considerable information concerning the constitution of the carbides was obtained, hovever, and ternary diagrams were constructed. The incomplete data on the compatibility and corrosion behavior of the carbides that were found in the literature were supplemented by thermodynamic calculations for various possible reactions with coolants and claddings.

Available information on preparation of bull carbides was reviewed and data on thermodynamics, preparation by chemical reactions, melting and casting, solid-phase fabrication, and storage and handling were assembled. Some information on the effects of irradiation of casi uranium monocarbide so burnups of up to 1.7 a/o of the uranium was collected and evaluated.

The results of the survey indicate that commercial production of bulk uranium carbide is feasible and that, on the basis of its radiation behavior, this material has excellent potential as a reactor fuel.

\section{INTRODUCTION}

As a result of promising irradiation results and favorable physical characteristics, uranium monocarbide has been revealed as a promising prospect for the fuel to be used in various types of reactors. At present, the Reactor Development Division of the U. S. Atomic Energy Commission is supporting several programs intended to further develop and evaluate bulk uranium carbides as fuels. Because of this current effort on carbides, it must be expected that any literature review will be quickly outdated. Nonetheless, a review and evaluation of the literature is needed as a basis for this research. In carrying out the review, no attempt was made to review research in progress, although the authors have drawn considerably upon Battelle research and experience for the details needed to give the report some depth.

For a summary of current research, the reader is referred to TID-7589, "Progress in Carbide Fuels", May, 1960, which contains summaries of the research being conducted at various laboratories.

While considerable information is compiled in this report for uranium carbides, very little information is available for thorium and plutonium carbides. The information that was found is reported with the uranium carbide data. No attempt was made to include information on fuel types other than bulk carbides, such as dispersions and cermets. 
Considerable information is available on the constitution of the carbides, and, wherever possible, the corresponding ternary diagrams have been constructed. Very limited data are reported on the physical and mechanical properties of uranium carbides. Additional research is needed to establish and understand the effects of composition, impurities, and fabrication history upon the temperature dependence of the rmal conductivity. High-temperature mechanical-property data are completely lacking. Incomplete data on the compatibility and corrosion behavior of carbides have been assembled. These data are supplemented by thermodynamic calculations for various possible reactions with coolants and claddings.

Information available on methods of preparation of uranium carbides is reviewed. In general only the results of laboratory-scale experiments are available. Thermodynamic data relating to the various methods of preparation have been assembled and are presented. Serious effort on methods for the commercial preparation of uranium. carbide as powder and also in forms suitable for feed for arc-melting processes is needed.

Information is available upon several methods of fabricating bulk uranium carbide into pellets or cast slugs. With respect to powder methods of forming, additional effort is needed in a few of the more promising areas. Unfortunately, discernment of any promising areas depends, in turn, upon advancement of the technology of production of powders. Preparation of uranium carbides by casting techniques has received considerable study, and pilot-plant operations to establish production procedures and estimates of expected costs are in order. Commercial feed material is needed even for the latter process.

The effects of irradiation on uranium carbide are reviewed, and, although only a limited number of tests have been performed, almost exclusively on high-density ascast slugs of uranium monocarbide, the results are promising. The tests represent burnups of up to 1.7 a/o uranium $(10,000 \mathrm{MWD} / \mathrm{T}$ of uranium) at modest temperatures. Much additional testing is required to evaluate carbides for various specific applications. 


\title{
PROPERTIES OF NUCLEAR CARBIDES
}

\author{
W. M. Phillips
}

\section{Physical Properties}

The melting points, crystal structures, specific heats, and electrical resistivities of uranium, thorium, and plutonium carbides, insofar as they are presently available, are summarized in Table $1^{(1-13)}$ and are discussed briefly below. Thermal conductivities, thermal-expansion coefficients, and the mechanical properties are also summarized in this section. (14-18) Thermodynamic properties, however, appear in the section of this report on preparation and fabrication of nuclear carbides.

The melting-point data are, in general, mean values of several published values which are all within $\pm 100 \mathrm{C}$ of the values listed. The crystal-structure and latticeparameter data for the uranium and thorium carbides were obtained by $\mathrm{X}$-ray and neutron-diffraction techniques $(5,9)$. Those for the plutonium carbides were determined by $\mathrm{X}$-ray diffraction techniques only.

Analysis of the interatomic distances in uranium carbides reveals considerable information about the nature of the bonding. (9) The interatomic distances in uranium carbides are shown in Table 2. In uranium monocarbide, four of the valence electrons of uranium appear to be involved in covalent bonding with the uranium and carbon atoms. The remaining two valence electrons are available for metallic bonding, accounting for the high thermal conductivity and other metallic characteristics of uranium monocarbide. In $\mathrm{U}_{2} \mathrm{C}_{3}$, the bond between the uranium and carbon atoms is not quite as strong, and covalent bonds are found between adjacent carbon atoms, perhaps accounting for the higher hardness of $\mathrm{U}_{2} \mathrm{C}_{3}$. In $\mathrm{UC}_{2}$, most of the uranium-carbon bonds are quite weak, and strong, covalent bonding between carbon atoms is indicated. (9)

The electrical resistivity of uranium carbide has been reported for both sintered specimens and cast specimens (Table 1). The unusually high value of $100 \mathrm{microhm}-\mathrm{cm}$

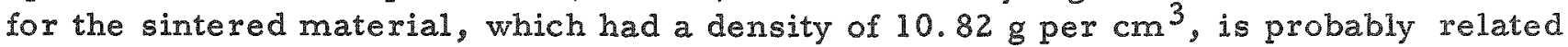
to the low density. The resistivities of about 100 cast specimens, ranging in composition from 4.8 to $5.0 \mathrm{w} / 0$ carbon, have been measured. The resistivities obtained ranged from 35 to $45 \mathrm{microhm-cm}$; the mean value being about 40 microhm-cm. Earlier work produced values of $33,44,(13)$ and 99 microhm-cm (19). The latter high value may have been the result of deterioration or cracking of the sample from exposure to moisture during handling. Recent experience $(18)$ has shown that impurity variations of less than $800 \mathrm{ppm}$ of iron, nickel, silicon, and tungsten have no significant effect upon the resistivity of cast carbides. The impurities in typical as-cast material amount to about $200 \mathrm{ppm}$ of which about 100 to $110 \mathrm{ppm}$ is oxygen.

The available data for the thermal conductivities of uranium monocarbide and uranium dicarbide are shown in Table 3 and in Figure 1. The se data seem to indicate that a carbon content in the range of 4.8 to $5.3 \mathrm{w} / \mathrm{o}$ does not have a significant effect upon thermal conductivity. The temperature dependence of the rmal conductivity in this range of composition is not clear.

Thermal-expansion data for uranium monocarbide are shown in Figure 2. The most reliable data are believed to be those for the cast material. (14) Significantly 
TABLE 1. PHYSICAL PROPERTIES OF URANIUM, THORIUM, AND PLUTONIUM CARBIDES $\$$ (1-13)

\begin{tabular}{|c|c|c|c|c|c|c|c|}
\hline & UC & $\mathrm{U}_{2} \mathrm{C}_{3}$ & $\mathrm{UC}_{2}$ & PuC & $\mathrm{Pu}_{2} \mathrm{C}_{3}$ & ThC & $\mathrm{ThC}_{2}$ \\
\hline Melring Point, $C$ & 2400 & Decomposes at $1775 \mathrm{C}$ & 2400 & 1850 & 1900 & 2625 & 2655 \\
\hline Crystal Structure & Fcc, $\mathrm{NaCl}$ type & $\mathrm{Bcc}$ & Bet, $\mathrm{CaC}_{2}$ type & Fcc, $\mathrm{NaCl}$ type & $\mathrm{Bcc}$ & Fcc, $\mathrm{NaCl}$ type & Monoclinic \\
\hline Lattice Parameters, A & $a=4.9598 \pm 0.0003$ & $a=8.0885 \pm 0.0005$ & $\begin{array}{l}a=3.509 \pm 0.003 \\
c=5.980 \pm 0.005\end{array}$ & $a=4.97$ & $a=8.129$ & $a=5.34$ & $\begin{array}{l}a=6.53, b=4.24 \\
c=6.56 ; \beta=104^{\circ}\end{array}$ \\
\hline $\begin{array}{l}\text { Theoretical Density, } \\
\text { g per } \mathrm{cm}^{3}\end{array}$ & 13.63 & 12.88 & 11.68 & 13.6 & 12.7 & -- & -- \\
\hline $\begin{array}{l}\text { Specific Heat, } \\
\mathrm{cal} /(\mathrm{g})(\mathrm{C})\end{array}$ & $\begin{array}{c}0.048 \pm 0.003(125 \mathrm{C}) \\
0.053 \pm 0.003(250 \mathrm{C})\end{array}$ & $\cdots$ & $-\infty$ & -- & -- & -- & -- \\
\hline $\begin{array}{l}\text { Electrical Resistivity, } \\
\text { microhm-cm }\end{array}$ & $\begin{array}{l}100 \pm 4 \text { (sintered; density, } \\
10.82 \mathrm{~g} \text { per } \mathrm{cm}^{3} \text { ) } \\
40 \text { (as cast; density, } \\
98 \text { per cent) }\end{array}$ & - & $-\infty$ & $-\infty$ & -- & -- & - \\
\hline
\end{tabular}


TABLE 2. INTERATOMIC DIST ANCES IN URANIUM CARBIDES(9)

\begin{tabular}{|c|c|c|c|c|}
\hline \multirow[b]{2}{*}{ Compound } & \multirow[b]{2}{*}{ Atom } & \multicolumn{2}{|c|}{ Adjacent Atoms } & \multirow[b]{2}{*}{ Interatomic Distance, A } \\
\hline & & Number & Type & \\
\hline \multirow[t]{3}{*}{ UC } & Uranium & 12 & Uranium & 3.50 \\
\hline & Uranium & 6 & Carbon & 2.48 \\
\hline & Carbon & 12 & Carbon & 3.50 \\
\hline \multirow[t]{7}{*}{$\mathrm{U}_{2} \mathrm{C}_{3}{ }^{(\mathrm{a})}$} & Uranium & 3 & Uranium & 3.34 \\
\hline & Uranium & 2 & Uranium & 3.48 \\
\hline & Uranium & 6 & Uranium & 3.48 \\
\hline & Uranium & 3 & Carbon & 2.50 \\
\hline & Uranium & 3 & Carbon & 2.56 \\
\hline & Uranium & 3 & Carbon & 2.82 \\
\hline & Carbon & $\infty$ & Carbon & 1.295 \\
\hline \multirow[t]{5}{*}{$U C_{2}$} & Uranium & 8 & Uranium & 3.90 \\
\hline & Uranium & 4 & Uranium & 3.54 \\
\hline & Uranium & 2 & Carbon & 2.325 \\
\hline & Uranium & 8 & Carbon & 2.59 \\
\hline & Carbon & - & Carbon & 1.34 \\
\hline
\end{tabular}

(a) For $X_{U} \approx 0.050$ and $X_{C} \approx 0.295$.

TABLE 3. THERMAL CONDUCTIVITY OF UC AND UC 2

\begin{tabular}{|c|c|c|c|c|c|c|}
\hline \multirow[b]{2}{*}{$\begin{array}{c}\text { Temperaure, } \\
\text { C }\end{array}$} & \multicolumn{6}{|c|}{ Thermal Conductivity of Material Shown, $\mathrm{cal} /(\mathrm{cm})(\mathrm{sec})(\mathrm{C})$} \\
\hline & $\begin{array}{c}\text { Arc-Cast } \\
\text { U-5.2 w/o C } \\
{[\text { Reference }(14)]}\end{array}$ & $\begin{array}{c}\text { ArC-Cast } \\
\text { U-4.9 w/o C } \\
{[\text { Reference }(17)]}\end{array}$ & $\begin{array}{c}\text { Arc-Cast } \\
\text { U-5.3 w/o C } \\
\text { [Reference (17)] }\end{array}$ & $\begin{array}{c}\text { Sintered } \\
\mathrm{U}-4.8 \mathrm{~W} / \mathrm{O} \mathrm{C} \\
\text { [Reference (11)] }\end{array}$ & $\begin{array}{c}\text { Sintered } \\
\mathrm{U}-4.8 \mathrm{w} / 0 \mathrm{C} \\
{[\text { Reference (1)] }}\end{array}$ & $\begin{array}{c}\text { Sintered(a) } \\
\text { UC }_{2} \\
\text { [Reference (15)] }\end{array}$ \\
\hline 20 & - & - & $-\infty$ & $\infty$ & 0.078 & $-\infty$ \\
\hline 45 & $-\infty$ & $-\infty$ & $\infty$ & $-\infty$ & - & 0.079 \\
\hline 60 & - & $-\infty$ & $-\infty$ & 0.080 & $-\infty$ & $=$ \\
\hline 100 & 0.060 & -- & -- & $-\infty$ & $-\infty$ & -- \\
\hline 115 & $-\infty$ & $\infty$ & $-\infty$ & 0.074 & - & $=\infty$ \\
\hline 145 & $-\infty$ & $\infty=$ & $-\infty$ & 0.061 & $=$ & $=$ \\
\hline 200 & 0.056 & 0.056 & 0.056 & $-\infty$ & $-\infty$ & $-\infty$ \\
\hline 265 & - & $=-$ & $\infty$ & 0.050 & 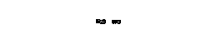 & $\omega-$ \\
\hline 300 & 0.054 & 0.053 & 0.055 & $-\infty$ & - & $\cdots$ \\
\hline 400 & 0.053 & 0.051 & 0.054 & $-\infty$ & -- & $\infty$ \\
\hline 500 & 0.053 & 0.050 & 0.054 & $\ldots$ & - & $=$ \\
\hline 600 & 0.057 & 0.049 & 0.054 & $-\infty$ & $-\infty$ & -- \\
\hline 700 & 0.060 & 0.049 & 0.054 & $-\infty$ & - & $-\infty$ \\
\hline 800 & $=$ & 0.049 & 0.054 & $=$ & $-\infty$ & $=-$ \\
\hline 900 & $-\infty$ & 0.048 & 0.054 & $-\infty$ & - & $\infty$ \\
\hline 1000 & - & 0.048 & 0.055 & $=$ & 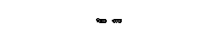 & $-\infty$ \\
\hline 1020 & $-\infty$ & 0.048 & $=$ & $-\infty$ & $=$ & $=$ \\
\hline
\end{tabular}

(a) Sintered to a density of $10 \mathrm{~g}$ per $\mathrm{cm}^{3}$. 


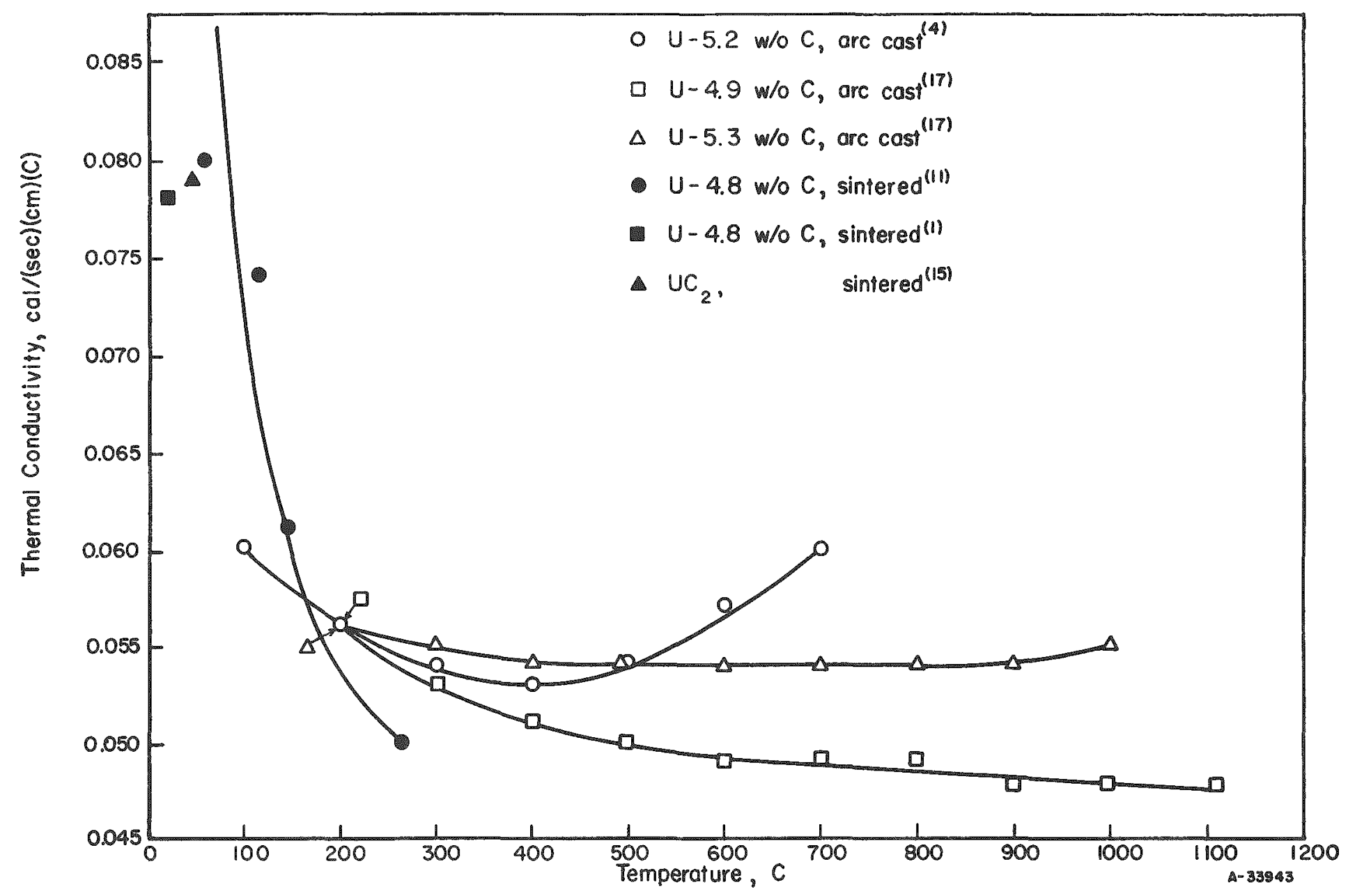

FIGURE 1. THERMAL CONDUCTIVITY OF UC AND UC 2 


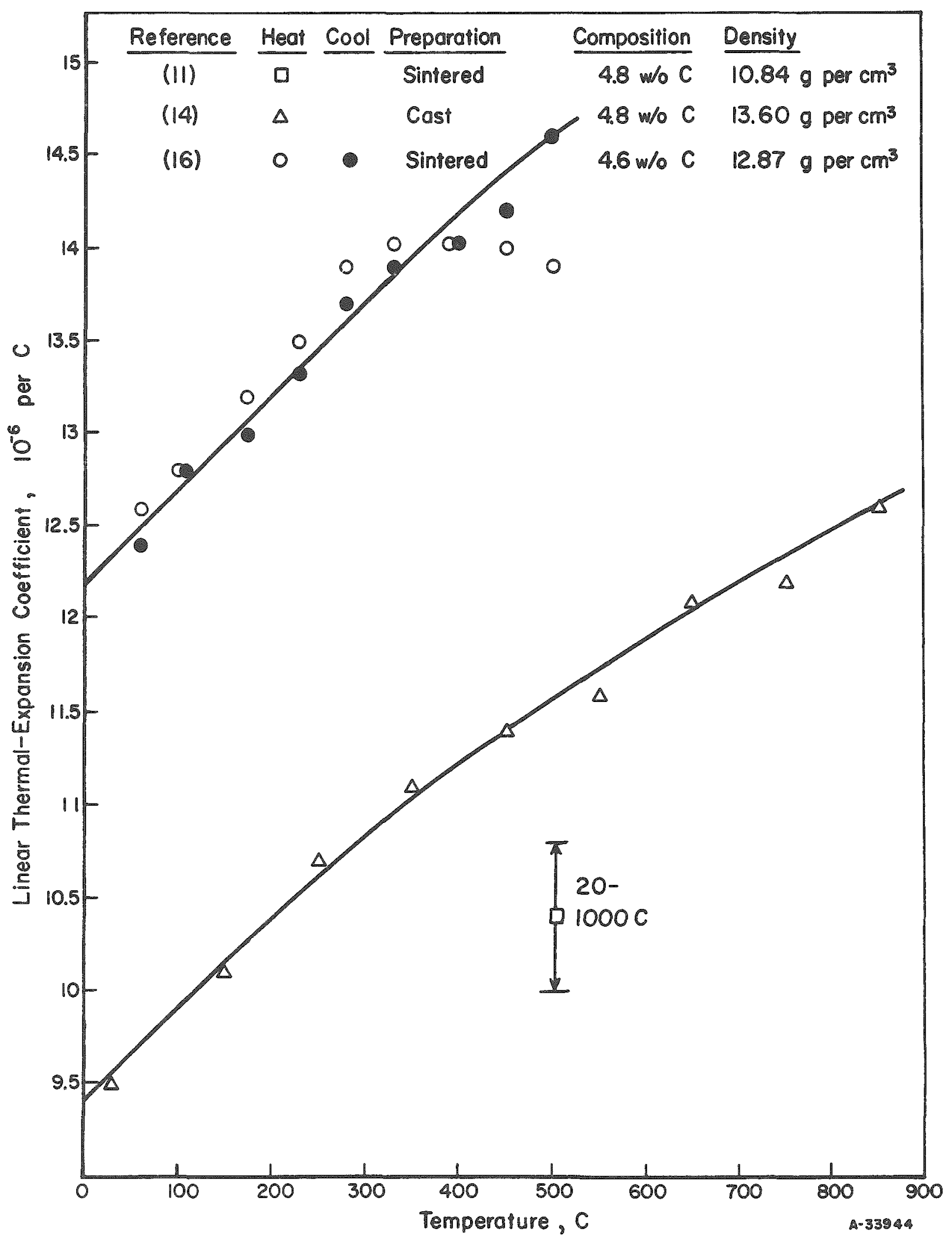

FIGURE 2. THERMAL-EXPANSION COEFFICIENTS OF URANIUM MONOCARBIDE 
higher and lower values have been obtained on sintered products. The higher values are believed to be the result of free uranium in the sintered product, but the reason for the lower mean value of $10.4 \times 10^{-6}$ per $C$ for 20 to $1000 \mathrm{C}$ is not evident.

\section{Mechanical Properties}

In general, data on mechanical properties, such as hardness, rupture strength, ductility, etc., are available only on carbides near UC in composition. Because of its covalent bonding and high melting point, uranium monocarbide should exhibit high strength at elevated tempexatures. However, it is known to be ductile at $1800 \mathrm{C}(20)$ and can be expected to show slight ductility at about $1300 \mathrm{C}$ (approximately 0.6 times its melting point on the absolute temperature scale) while retaining high strength. The room-temperature properties of uranium monocarbide are those one expects of a brittle material. The hardness of uranium carbide samples depends upon fabrication, heat treatment, and other variables, but it generally ranges from 560 to 800 VHN as shown in Table 4. Available data on the strength and modulus of elasticity of uranium monocarbide are also given in Table 4.

TABLE 4. SOME MECHANICAL PROPERTIES OF URANIUM-CARBON ALLOYS

\begin{tabular}{|c|c|c|c|c|c|}
\hline \multirow[b]{2}{*}{ Material } & \multirow{2}{*}{$\begin{array}{c}\text { Vickers } \\
\text { Hardness, } \\
\text { kg per } \text { mm }^{2}\end{array}$} & \multicolumn{2}{|c|}{ Rupture Strength, psi } & \multirow{2}{*}{$\begin{array}{l}\text { Elastic } \\
\text { Modulus, } \\
10^{6} \mathrm{psi}\end{array}$} & \multirow[b]{2}{*}{ Reference } \\
\hline & & Transverse & Compressive & & \\
\hline Cast U-4.6 W/oC & 900 & 9,600 & -- & -- & (18) \\
\hline \multicolumn{6}{|l|}{ Cast U-5.2 w/o C } \\
\hline As cast & 600 & $-\infty$ & 54,500 & 31.5 & (14) \\
\hline Annealed 1 hr at $1000 \mathrm{C}$ & 560 & $-\infty$ & $-\infty$ & -- & (14) \\
\hline Arnealed 1 hr at $1500 \mathrm{C}$ & 760 & -- & -- & $-\infty$ & (14) \\
\hline Cast $U-7$ w $/ 0 \mathrm{C}$ & 850 & 13,000 & -- & - & (18) \\
\hline Sintered UC & $750-800$ & $40,000-55,000$ & $-\infty$ & - & (2) \\
\hline \multicolumn{6}{|l|}{ Sintered UC } \\
\hline Density, $10.84 \mathrm{~g}$ per $\mathrm{cm}^{3}$ & $700 \pm 150$ & - & $42.500 \pm 5.500$ & $-\infty$ & (11) \\
\hline Density, $10.2 \mathrm{~g}_{\mathrm{ger}} \mathrm{cm}^{3}$ & $550 \pm 150$ & $-\infty$ & $\ldots$ & $-\infty$ & (11) \\
\hline
\end{tabular}

In general, $\mathrm{U}_{2} \mathrm{C}_{3}$ and $\mathrm{UC}_{2}$ are also quite brittle, since both have covalent uranium-carbon and carbon-carbon bonding. Uranium sesquicarbide appears to be harder than UC, having a hardness of abovt $1100 \mathrm{Knoop}$. (18) Uranium dicarbide is believed to have a hardness of about 500 Knoop. (18) Neither $U_{2} C_{3}$ nor UC $\mathrm{UC}_{2}$ is expected to compare with UC in mechanical strength at high temperatures, since $\mathrm{U}_{2} \mathrm{C}_{3}$ decomposes peritectoidally at about $1775 \mathrm{C}$, and tetragonal $\mathrm{UC}_{2}$ is stable only to about $1800 \mathrm{C}$.

Additions of $1 \mathrm{w} / \mathrm{O}$ of the soluble carbides (VC, NbC, TiC, ZrC, and TaC) have been made to UC by melting and casting. (18) The resultant hardnesses were about 700 Knoop as compared with 600 Knoop for unalloyed, cast UC. Carbide castings containing additions of $10 \mathrm{w} / 0$ of the same carbides possessed hardnesses of 1200 to 1400 Knoop and demonstrated up to 50 per cent increases in the modulus of rupture. 


\section{References}

(1) Dubuisson, J., Houyvet, A., Le Boulbin, E., Lucas, R., and Moranville, C., "The Preparation of Uranium-Uranium Carbide Cermets and Stoichiometric Monocarbide by Sintering Under Stress", Proceedings of the Second United Nations International Conference on the Peaceful Uses of Atomic Energy, Geneva (1958), Vol 6, A/Conf./P/1162, pp 551-60.

(2) Keiffer, R., Benesovsky, F., and Nowotny, H., "The Preparation of Uranium Monocarbide and Its Behavior Compared With Other High-Melting Carbides", Planseeber Pulvermet. 5, 33-5 (1957); IGRL T/C-52.

(3) Chiotti, P., "Thorium-Carbon System", AECD-3072 (February 27, 1951).

(4) Wilhelm, H. A., and Chiotti, P., "Thorium-Carbon System", Trans. ASM, 42, $1295-1310(1950)$.

(5) Hunt, E. B., and Rundle, R. E., "Structure of Thorium Carbide by X-Ray and Neutron Diffraction", J. Am. Chem. Soc., 73, 4777-81 (1951).

(6) Coffinberry, A. S., and Ellinger, F. H., "The Intermetallic Compounds of Plutonium", Proceedings of the [First United Nations] International Conference on the Peaceful Uses of Atomic Energy, New York (1956), Vol 9, A/Conf. $8 /$ P/826, pp $138-46$.

(7) Rough, F. A., and Chubb, W., "Progress on the Development of Uranium Carbide-Type Fuels", BMI-1370 (August 21, 1959).

(8) Rough, F. A., and Bauer, A. A., "The Constitution of Uranium and Thorium Alloy s", BMI-1300 (1958).

(9) Austin, A. E., "Carbon Positions in Uranium Carbide", Acta Cryst., 12, 159-61 (February 10, 1959).

(10) Rundle, R. E., Baenziger, N. C., Wilson, A. S., and McDonald, R. A., "The Structure of the Carbides, Nitrides, and Oxides of Uranium", J. Am. Chem. Soc., 70, 99-105 (1948).

(11) Boettcher, A., and Schneider, G., "Some Properties of Uranium Monocarbide", Proceedings of the Second United Nations Conference on the Peaceful Uses of Atomic Tnergy, Geneva (1958), Vol 6, A/Conf. 15/P/964, pp 561-63.

(12) Drummond, J. L., McDonald, B. J., Ockenden, H. M., and Welch, G. A., "The Preparation and Properties of Some Plutonium Compounds VIII, Plutonium Carbide", J. Chem. Soc. (London), p 4785 (1957).

(13) Smith, C. A., and Rough, F. A., "Properties of Uranium Monocarbide", NAA-SR-3625 (June 1, 1959).

(14) Secrest, A. C., Foster, E. L., and Dickerson, R. F., "Preparation and Properties of Uranium Monocarbide Castings", BMI-1309 (January 2, 1959). 
(15) Snyder, T. M., and Kamm, R. L., "Some Physical Constants Important in the Design of an Atomic Power Plant", C-192 (December, 1955).

(16) Tripler, A. B., Jr., Snyder, M. J., and Duckworth, W. H., "Further Studies of Sintered Refractory Uranium Compound", BMI-1313 (January 27, 1959).

(17) Dayton, R. W., and Tipton, C. R., Jr., "Progress Relating to Civilian Applications During August, 1959", BMI-1377 (September 1, 1959).

(18) Phillips, W. M., BMI, Unpublished Information.

(19) Foster, E. L., BMI, Unpublished Information.

(20) Wilson, W. B., "High-Temperature X-Ray Diffraction Investigation of the UraniumCarbon System", J. Am. Ceram. Soc., 43, 77-81 (February, 1960). 


\author{
URANIUM, THORIUM, AND PLUTONIUM CARBIDE SYSTEMS \\ W. Chubb
}

\title{
INTRODUCTION
}

\section{Diagrams}

Constitutional diagrams are presented only for those systems where diagrams are reported in the literature or where there are sufficient data to justify construction of an isothermal ternary section. Because many of these sections are constructed from fragmentary data, they must be considered as tentative. The sections are generally constructed at a temperature near $1000 \mathrm{C}$.

\section{Symbols}

All binary diagrams are presented with weight per cent $(w / 0)$ and atomic per cent (a/o) scales. All ternary diagrams are presented with atomic per cent (a/o) scales. All quaternary diagrams and pseudoternary diagrams are presented with mole per cent scales.

Greek letters are used only to describe those phases for which usage has established a clear precedent, as for example, "gamma" iron and "gamma" uranium. Intermetallics are shown in terms of their chemical stoichiometry or in terms of their crystal stoichiometry, if the latter is known.

No data are presented on the crystallography of phases in the binary metallic systems.

\section{References}

While pertinent references are cited in the discussions of the individual systems, the following publications were found extremely useful in compiling much of the information presented throughout this section:

\section{Uranium and Thorium}

(1) Bauer, A. A., and Rough, F. A., Constitution of Uranium and Thorium Alloys, Addison-Wesley Publishing Company, Reading, Massachusetts (1958); BMI-1300 (June, 1958).

(2) Bauer, A. A., and Rough, F. A., "Uranium Alloy Systems" and "Thorium Alloy Systems", Progress in Nuclear Energy, Series V, Metallurgy and Fuels, Pergamon Press, New York (1959), Vol 2, pp 600-11 and 612-20. 
Carbides

(1) Hansen, Mo, and Anderko, K. , Constitution of Binary Alloys, McGrawHill Book Company, Inc., New York (1958).

(2) Sheipline, V. M., and Runck, R. J., "Carbides", High Temperature Technology, John Wiley and Sons, New York (1956).

Plutonium

(1) Waldron, M. B., Garstone, J., Lee, J. A., Mardon, P. G., Marples, J.A.C., Poole, D. M., and Williamson, G. K., "The Physical MetalIurgy of Plutonium", Proceedings of the Second United Nations international Conference on the Peaceful Uses of Atomic Fnergy, Geneva (1958), Vol 6, A/Conf. 15/P/71, pp 162-69.

(2) Bochver, A. A. , Konobeevsky, S. T., Kutaitsev, V. I., Menshikova, T. S., and Chebotarev, N. T., "Interaction of Plutonium and Other Metals in Connection With Their Arrangement in Mendeleev's Periodic Table", Proceedings of the Second United Nations International Conference on the Peaceful Uses of Atomic Energy, Geneva (1958), Vol 6, A/Conf. $15 / \mathrm{P} / 2197, \mathrm{pp} 184-93$.

(3) Coffinberry, A. S., Schonfeld, F. W., Cramer, E. M., Miner, W. N., Ellingex, F. H., Elliott, R. O., and Struebing, V. O., "The Physical Metallurgy of Plutonium and Its Alloys", Proceedings of the Second United Nations International Conference on the Peaceful Uses of Atomic Energy, Geneva (1958), Vol 6, A/Conf. 15/P/1046, pp 681-85.

(4) Schonfeld, F.W., Cramer, E. M., Miner, W. N., Ellinger, F. H., and Coffinberry, A. S., "Plutonium Constitutional Diagrams", Progress in Nuclear Energy, Series V, Metallurgy and Fuels, Pergamon Press, New York (1959), Vol 2, pp 579-99.

\section{THE URANIUM-CARBON BINARY SYSTEM}

\section{Constitution}

The melting point of UC in contact with tungsten was determined to be $2280 \mathrm{C}$ by Newkirk and Bates(1). The melting point of UC was determined by Brownlee(2) by focusing an optical pyrometer on the liquid-solid interface of an arc melt and found to be $2520 \mathrm{C}$. Chiotti(3) found the melting point of UC to be $2590 \mathrm{C}$. Mallett, Gerds, and Nelson(4) found the melting point of UC to be $2390 \mathrm{C}$ and the melting point of $\mathrm{UC}_{2}$ to be $2480 \mathrm{C}$. Chubb and Phillips (5) have found metallographic evidence of a eutectic between 6.2 and $6.6 \mathrm{w} / 0$ carbon in cast samples of uranium-carbon alloys. Chubb and Phillips(5) also indicate a miscibility gap between $U C$ and $U C_{2}$ above $2200 \mathrm{C}$ in agreement with the suggestion of Hansen and Anderko(6). Chubb and Phillips(5) found evidence that the homogeneity range of cubic $\mathrm{UC}_{2}$ at about $1800 \mathrm{C}$ was from 7 to $9 \mathrm{w} / 0$ 
carbon; a eutectoid at 7 w/o carbon was indicated. This eutectoid results in the formation of $\mathrm{UC}$ and tetragonal $\mathrm{UC}_{2}$. The allotropy of $\mathrm{UC}_{2}$ was discovered by Wilson(7) using a high-temperature $\mathrm{X}$-ray camera.

Mallett, et al. , $(4,8)$ indicates that uranium sesquicarbide $\left(\mathrm{U}_{2} \mathrm{C}_{3}\right)$ is stable below $1775 \mathrm{C}$, forming by a sluggish or stress-sensitive nucleation process. The fact that the eutectoid at $7 \mathrm{w} / 0$ carbon and $1800 \mathrm{C}$ produces $\mathrm{UC}$ and $\mathrm{UC}_{2}$ rather than $\mathrm{U}_{2} \mathrm{C}_{3}$ and the fact that $\mathrm{UC}_{2}$ precipitates from UC containing 4.9 to $5.5 \mathrm{w} / \mathrm{o}$ carbon on cooling from high temperatures suggest that the temperature for peritectoid formation of $\mathrm{U}_{2} \mathrm{C}_{3}$ should be well below the eutectoid at $1800 \mathrm{C}$ and probably below $1775 \mathrm{C}$. Chubb and Phillips $(5)$ have produced equilibrium amounts of $\mathrm{U}_{2} \mathrm{C}_{3}$ in cast samples containing 5.7 to $7.8 \mathrm{w} / 0$ carbon by reheating to $1550 \mathrm{C}$ for $1 \mathrm{hr}$.

Blumenthal $(9)$ has obtained data indicating a eutectic at $0.05 \mathrm{w} / 0$ carbon and $1117 \mathrm{C}$ between UC and gamma uranium containing $0.015 \mathrm{w} / 0$ carbon. The solubility of carbon in liquid uranium is $0.1 \mathrm{w} / 0$ at $1300 \mathrm{C}$ and $0.15 \mathrm{w} / 0$ at $1400 \mathrm{C}$.

The uranium-carbon constitutional diagram is presented in Figure 3.

\section{Crystallography $(10)$}

UC: fcc (NaCl, Bl type), a $=4.9598 \mathrm{~A}$, four molecules per unit cell; density = $13.6 \mathrm{~g}$ per $\mathrm{cm}^{3}$.

$\mathrm{U}_{2} \mathrm{C}_{3}$ : bcc (space group I43d), $\mathrm{a}=8.0885 \mathrm{~A}$, eight molecules per unit cell; density $=12.5 \mathrm{~g}$ per $\mathrm{cm}^{3}$.

$\mathrm{UC}_{2}$ (below $1800 \mathrm{C}$ ): tetragonal $\left(\mathrm{CaC}_{2}, \mathrm{Cl} 1 \mathrm{a}\right.$ type), $\mathrm{a}=3.509 \mathrm{~A}, \mathrm{c}=5.980 \mathrm{~A}$, two molecules per unit cell; density $=11.7 \mathrm{~g}$ per $\mathrm{cm}^{3}$.

$\mathrm{UC}_{2}$ (above $1800 \mathrm{C}$ ): fcc $\left(\mathrm{CaF}_{2}, \mathrm{Cl}\right.$ type), $\mathrm{a}=5.47 \mathrm{~A}$ (at $1820 \mathrm{C}$ ), four molecules per unit cell.

\section{Reierences}

(1) Newkirk, H. W., and Bates, J. L., "The Melting Points of UO, UC, and UN", HW-59468 (March, 1959).

(2) Brownlee, L. D., "The Pseudo-Binary Systems of UC With ZrC, TaC, and $\mathrm{NbC}^{\prime \prime}, \mathrm{J}$. Inst. Metals, 87, 58-61 (October, 1958).

(3) Chiotti, P., "Experimental Refractory Bodies of High-Melting Nitrides, Carbides, and Uranium Dioxide", J. Am. Ceram. Soc., 35, 123-30 (May, 1952).

(4) Mallett, M. W., Gerds, A. F., and Nelson, H. R., "The UraniumCarbon System", J. Electrochem. Soc., 99, 197-204 (May, 1952).

(5) Chubb, W., and Phillips, W. M., "Constitution of the Partial Sy stem: $\mathrm{UC}-\mathrm{UC}_{2}$ ", to be published. 


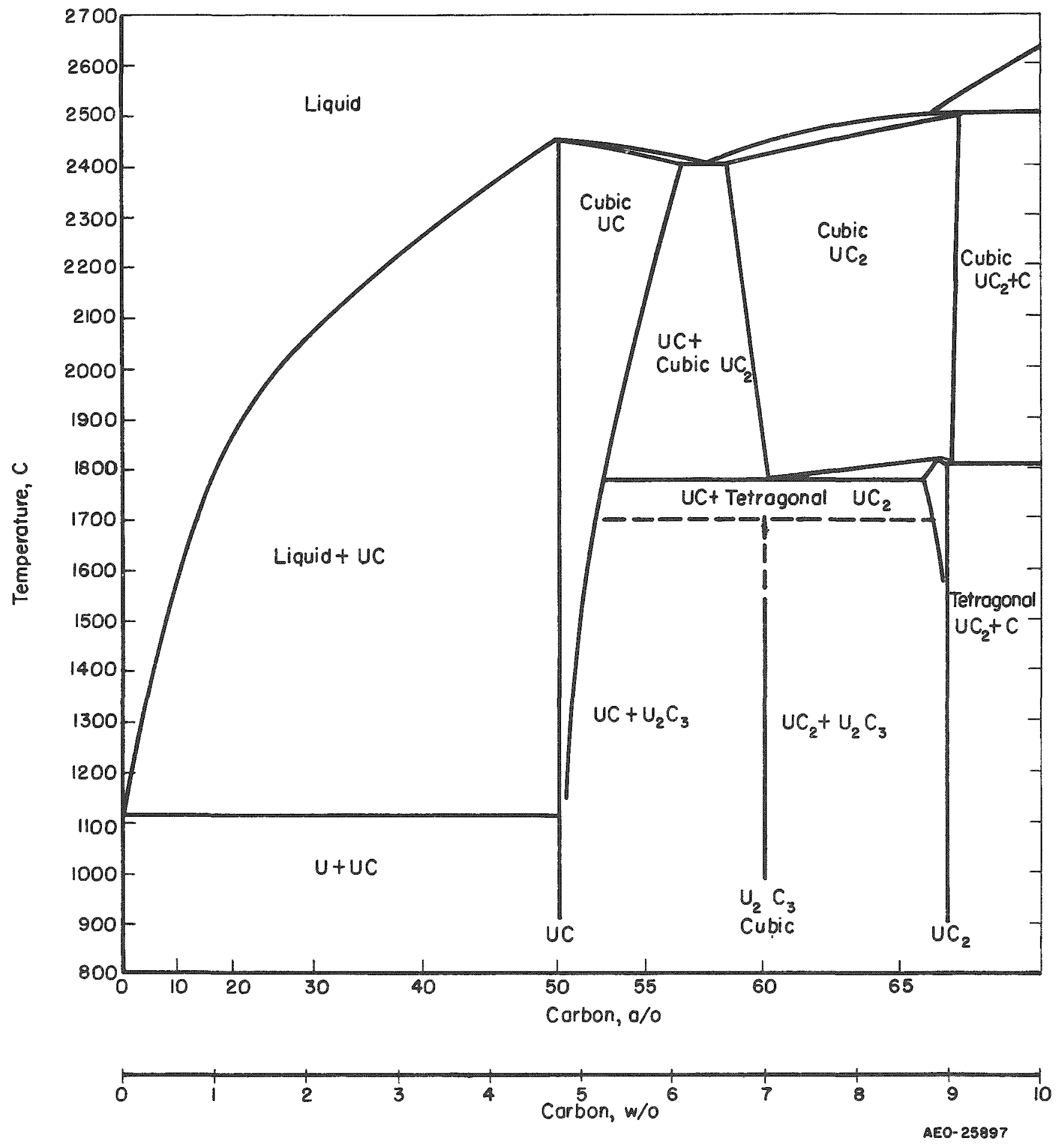

FIGURE 3. URANIUM-CARBON CONSTITUTIONAL DIAGRAM 
(6) Hansen, M., and Anderko, K., "Constitution of Binary Alloys", McGraw-Hill Book Company, New York (1958).

(7) Wilson, W. B., "High-Temperature X-Ray Diffraction Investigation of the Uranium-Carbon System", J.Am. Ceram. Soc., 43, 77-81 (February, 1960).

(8) Mallett, M. W., Gerds, A. F., and Vaughan, D. S., "Uranium Sesquicarbide", J. Electrochem. Soc., 98, 505-9 (December, 1951).

(9) Blumenthal, B. "Constitution of Low Carbon Uranium-Carbon Alloys", ANL-5958 (February, 1959).

(10) Austin, A. E., "Carbon Positions in Uranium Carbides", Acta Cryst., 12, 159-61 (February 10, 1959).

\section{URANIUM-CARBON TERNARY SYSTEMS}

\section{Aluminum}

\section{Constitution}

The ternary section shown in Figure 4 is based on statements by Thurber and Beaver(1) to the effect that UC reacts with aluminum to produce $\mathrm{UA}_{3}$ and $\mathrm{UAl}_{4}$; and that some $\mathrm{UAl}_{3}$ or $\mathrm{UAl}_{4}$ was detected by $\mathrm{X}$-ray in samples of uranium-carbon alloys containing more than $7 \mathrm{w} / 0$ carbon after being in contact with aluminum for $24 \mathrm{hr}$ at $620 \mathrm{C}$. They found that $\mathrm{UC}_{2}$ showed negligible reaction with aluminum, suggesting a pseudobinary between $\mathrm{UC}_{2}$ and aluminum.

The melting point of $\mathrm{Al}_{4} \mathrm{C}_{3}$ is above $2800 \mathrm{C}$.

\section{Crystallography}

$\mathrm{Al}_{4} \mathrm{C}_{3}:$ rhombohedral (D7 type), $a=8.55 \mathrm{~A}, \alpha=22^{\circ} 18^{\prime}$, one molecule per unit cell; density $=2.99 \mathrm{~g}$ per $\mathrm{cm}^{3}$.

\section{Reference}

(1) Thurber, W. C., and Beaver, R. J., "Dispersions of Uranium Carbides in Aluminum Plate-Type Research Reactor Fuel Elements", ORNL-2618 (November, 1959). 
Beryllium

Constitution

Burdick, Parker, Roth, and McGandy $(1)$ indicate that there is no solubility of UC or $\mathrm{UC}_{2}$ in $\mathrm{Be}_{2} \mathrm{C}$, but that UC dissolves 40 and 20 mole per cent $\mathrm{Be}_{2} \mathrm{C}$ at 1900 and $1700 \mathrm{C}$, respectively. The solubility of $\mathrm{Be}_{2} \mathrm{C}$ in $\mathrm{UC}$ decreases to 6 mole per cent at temperatures below $1700 \mathrm{C}$. No ternary phases were found between $\mathrm{UC}, \mathrm{UC}_{2}$, and $\mathrm{Be}_{2} \mathrm{C}$. The solubility of $\mathrm{Be}_{2} \mathrm{C}$ in $\mathrm{UC}_{2}$ is negligible.

Ivanov and Badayeva(2) report that pseudobinary sections exist between UC and $\mathrm{UBe} 13$, between $\mathrm{UBe}_{13}$ and $\mathrm{Be}_{2} \mathrm{C}$, and between $\mathrm{UC}$ and $\mathrm{Be}_{2} \mathrm{C}$. Eutectics are found in the $\mathrm{UC}-\mathrm{Be}_{2} \mathrm{C}$ and in the UBe $13-\mathrm{UC}$ sections. No ternary compounds are formed.

The ternary section shown in Figure 5 is based on information provided by both the above sources.

The $\mathrm{Be}_{2} \mathrm{C}$ phase decomposes at about $2200 \mathrm{C}$.

\section{Crystallography}

$\mathrm{Be}_{2} \mathrm{C}:$ fcc $\left(\mathrm{CaF}_{2}, \mathrm{Cl}\right.$ type $), a=4.34 \mathrm{~A}$, four molecules per unit cell; density = $2.44 \mathrm{~g}$ per $\mathrm{cm}^{3}$.

References

(1) Burdick, M. D., Parker, H. S., Roth, R. S., and McGandy, E. L., "An X-Ray Study of the System: UC, UC2, Be $2 C^{C "}$, J. Research Natl. Bur. Standards, 54, 217-29 (April, 1955).

(2) Ivanov, O. S., and Badayeva, T. A., "Phase Diagrams of Certain Uranium and Thorium Systems", Proceedings of the Second United Nations International Conference on the Peaceful Uses of Atomic Energy, Geneva (1958), Vol 6, A/Conf. 15/P/2043, p 139.

\section{Chromium}

\section{Constitution}

Nowotny, Kieffer, and Benesovsky(1) report that $\mathrm{UC}$ and $\mathrm{Cr}_{3} \mathrm{C}_{2}$ are not soluble in one another. Ivanov and Badayeva(3) report no solubility between UC and chromium. A ternary section is presented in Figure 6.

$\mathrm{Cr}_{3} \mathrm{C}_{2}$ melts at about $1900 \mathrm{C}$.

$\mathrm{Cr}_{7} \mathrm{C}_{3}$ melts at about $1700 \mathrm{C}$.

$\mathrm{Cr}_{23} \mathrm{C}_{6}$ decomposes peritectically at about $1550 \mathrm{C}$. 


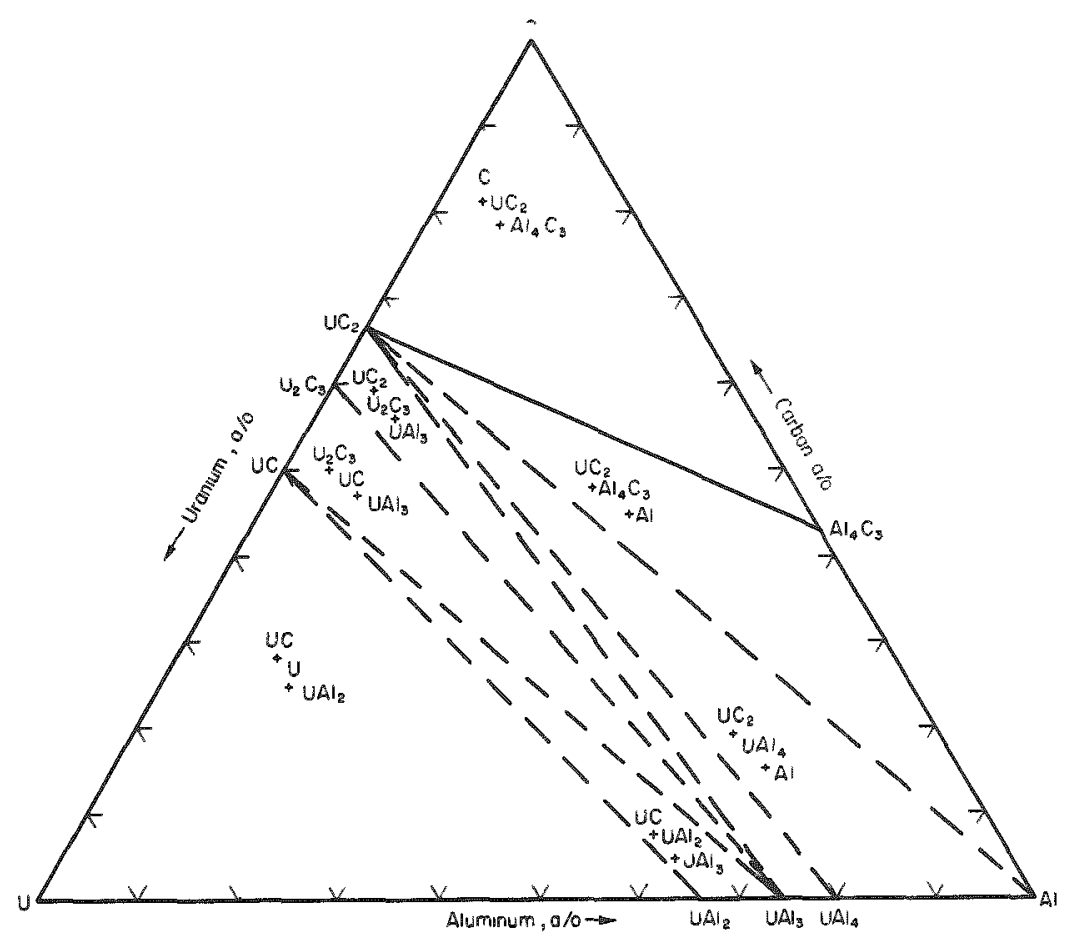

FIGURE 4. URANIUM-CARBON-ALUMINUM TERNARY SECTION AT 600 C

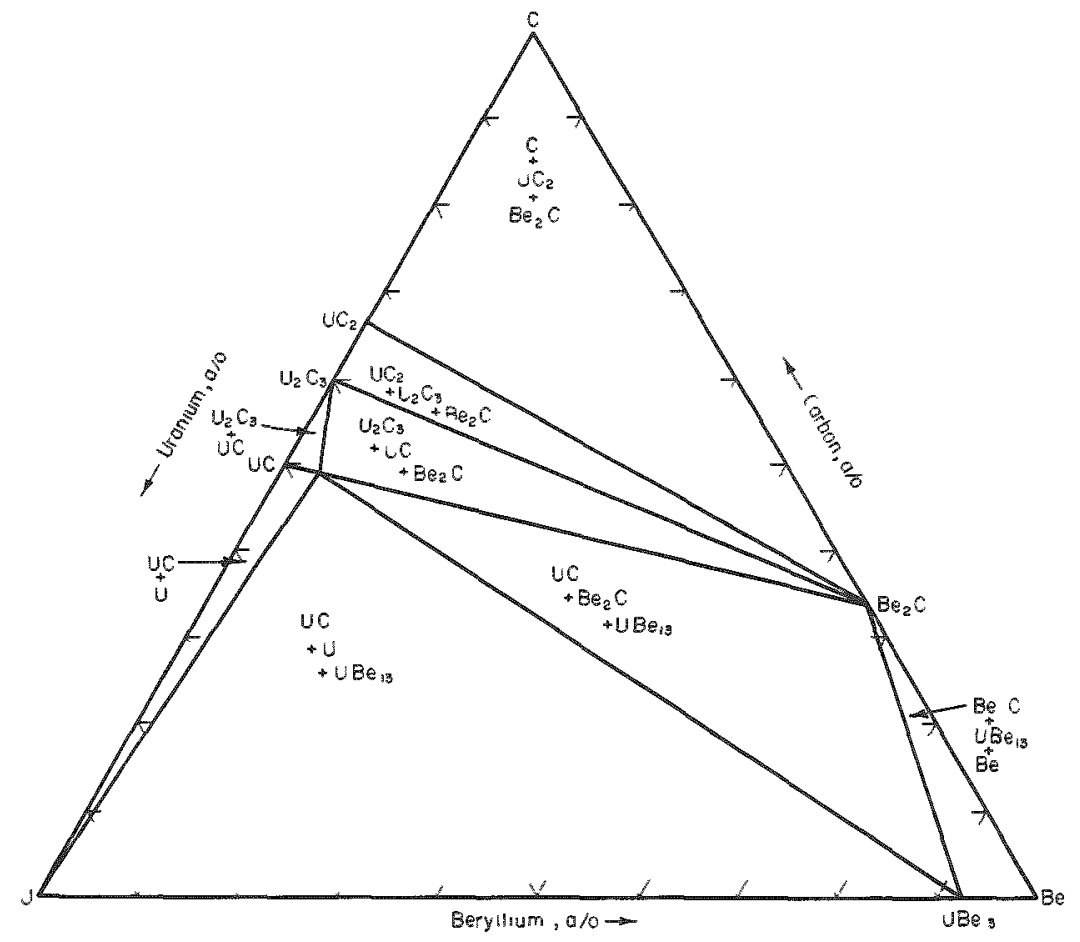

FIGURE 5. URANIUM-CARBON-BERYLLIUM TERNARY SECTION AT $1000 \mathrm{C}$ 
Crystallography

$\mathrm{Cr}_{3} \mathrm{C}_{2}$ : orthorhombic (D5 10 type), $\mathrm{a}=2.82 \mathrm{~A}, \mathrm{~b}=5.52 \mathrm{~A}, \mathrm{c}=11.46 \mathrm{~A}$, four molecules per unit cell; density $=6.7 \mathrm{~g}$ per $\mathrm{cm}^{3}$.

$\mathrm{Cr}_{7} \mathrm{C}_{3}$ : hexagonal, $\mathrm{a}=14.00 \mathrm{~A}, \mathrm{c}=4.52 \mathrm{~A}$, eight molecules per unit cell; density $=6.9 \mathrm{~g}$ per $\mathrm{cm}^{3}$.

$\mathrm{Cr}_{23} \mathrm{C}_{6}:$ fcc $(\mathrm{D} 84$ type), $a=10.64 \mathrm{~A}$, four molecules per unit cell; density $=$ $7.0 \mathrm{~g}$ per $\mathrm{cm}^{3}$.

\section{$\underline{\text { References }}$}

(1) Nowotny, H. , Kieffer, R., and Benesovsky, F., "Preparation of UC and Its Relation to the Carbides of Refractory Transition Metals", Rev. met. , 55, 453-58 (May, 1958); see also Reference (2).

(2) Nowotny, H., Kieffer, R., Benesovsky, F., and Laube, E., "Contribution to the Knowledge of the Partial Systems: UC with TiC, ZrC, VC, $\mathrm{NbC}, \mathrm{TaC}, \mathrm{Cr} 3 \mathrm{C}_{2}, \mathrm{Mo} 2 \mathrm{C}$, and WC", Monatsh. Chem., 88, 336-43 (June, 1957).

(3) Ivanov, O. S., and Badayeva, T. A., "Phase Diagrams of Certain Uranium and Thorium Systems", Proceedings of the Second United Nations International Conference on the Peaceful Uses of Atomic Energy, Geneva (1958), Vol 6, A/Conf. 15/P/2043, p 139.

\section{Cobalt}

\section{Constitution}

Bowman (1) reports that cobalt may be added to UC to aid sintering at 2000 to $2200 \mathrm{C}$ and removed later by vacuum treatment at these temperatures. This would indicate a pseudobinary of the UC-chromium type between UC and cobalt at least up to 2200 C. A uranium-carbon-cobalt ternary section is shown in Figure 7.

Crystallography

The compounds $\mathrm{Co}_{2} \mathrm{C}$ and $\mathrm{Co}_{3} \mathrm{C}$, if they exist, apparently decompose at temperatures above about $300 \mathrm{C}$.

\section{$\underline{\text { Reference }}$}

(1) Bowman, M. G., "Bonding Uranium Carbide to Tantalum", AECU-4303 (May, 1959). 


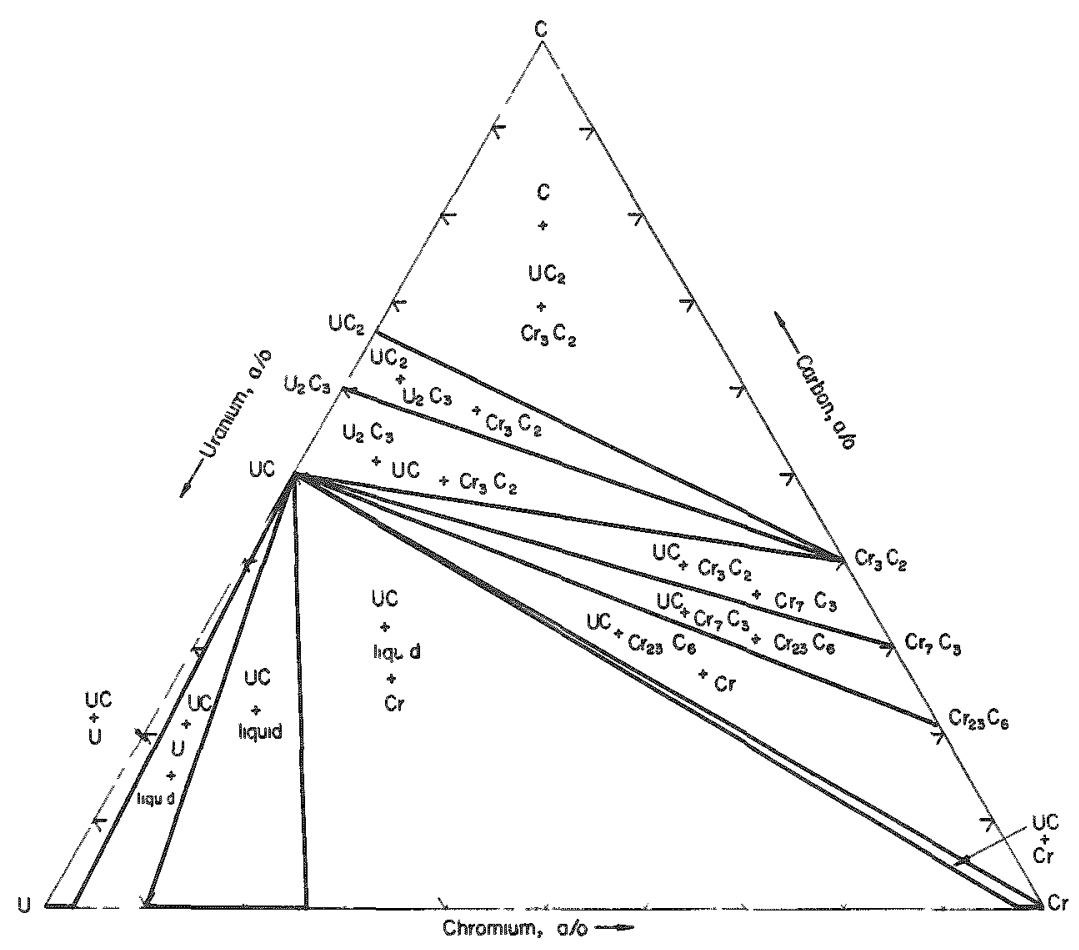

FIGURE 6. URANIUM-CARBON-CHROMIUM TERNARY SECTION AT $1000 \mathrm{C}$

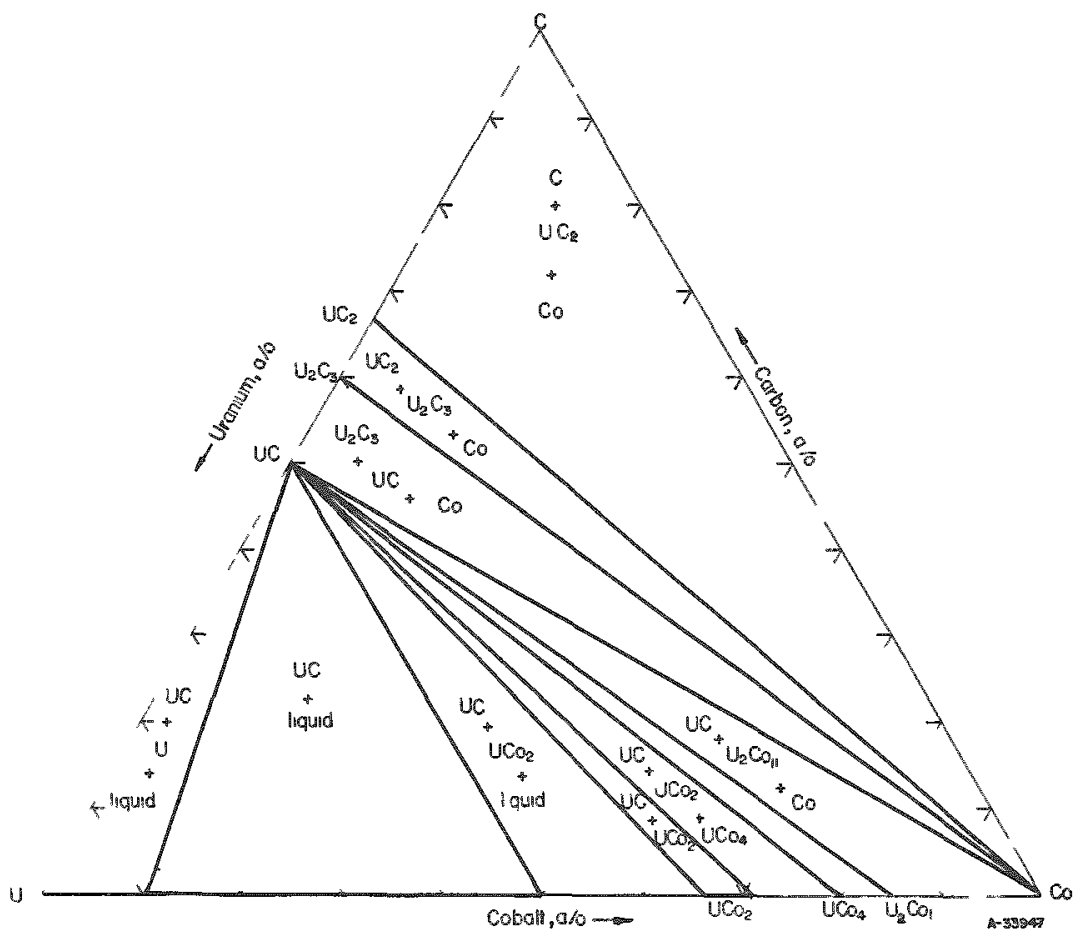

FIGURE 7. URANIUM-CARBON-COBALT TERNARY SECTION AT $1000 \mathrm{C}$ 


\section{Copper}

Constitution

Bowman(1) reports that copper may be added to UC to aid sintering at 2000 to $2200 \mathrm{C}$ and removed later by vacuum treatment at these temperatures. This would indicate a pseudobinary of the UC-chromium type between UC and copper at least up to $2200 \mathrm{C}$. A ternary section is shown in Figure 8.

\section{Crystallography}

The carbides of copper are reported by Meerson and Umanskii(2) to be unstable to the point of explosiveness.

\section{$\underline{\text { References }}$}

(1) Bowman, M. G., "Bonding Uranium Carbide to Tantalum", AECU-4303 (May, 1959).

(2) Meerson, G. A., and Umanskii, I. S., "On the Hardness of Refractory Carbides", Izvest. Sektora Fiz. Khim. Anal., 22, 104 (1953).

\section{Hafnium}

\section{Constitution}

The nature of the uranium-hafnium binary system has been reported recently by Peterson and Beerntsen(1). Since the unit-cell size of HfC is only 7 per cent smaller than that of UC, complete solubility between $\mathrm{UC}$ and $\mathrm{HfC}$ is to be expected. While HfC exists over a range of compositions, the composition limits have not been reported.

Although it is not known, the ternary section of the uranium-carbon-hafnium system is expected to resemble the uranium-carbon-thorium system section at $1000 \mathrm{C}$.

HfC melts at about $3900 \mathrm{C}$.

\section{Crystallography}

HfC: fcc ( $\mathrm{NaCl}, \mathrm{Bl}$ type), $a=4.64 \mathrm{~A}$, four molecules per unit cell; density = $12.2 \mathrm{~g}$ per $\mathrm{cm}^{3}$.

\section{$\underline{\text { Reference }}$}

(1) Peterson, D. T., and Beerntsen, D. J., "The Uranium-Hafnium Equilibrium System", Trans. ASM, 52, 763-80 (1960). 
Iron

\section{Constitution}

Bowman(1) reports that iron may be added to UC to aid sintering at 2000 to $2200 \mathrm{C}$ and then removed by vacuum treatment at the se temperatures. This would indicate a pseudobinary of the UC-chromium type between UC and iron up to about $2200 \mathrm{C}$.

$\mathrm{Fe}_{3} \mathrm{C}$ is metastable and decomposes rapidly at temperatures above $1200 \mathrm{C}$.

The uranium-carbon-iron diagram at $1000 \mathrm{C}$ is shown in Figure 9.

\section{Crystallography} $\mathrm{cm}^{3}$.

Fe ${ }_{3} \mathrm{C}$ : orthorhombic, $a=4.52 \mathrm{~A}, \mathrm{~b}=5.08 \mathrm{~A}, \mathrm{c}=6.74 \mathrm{~A}$; density $=7.67 \mathrm{~g}$ per

Fe 2 C: hexagonal or orthorhombic; density $=7.2 \mathrm{~g}$ per $\mathrm{cm}^{3}$.

\section{Reference}

(1) Bowman, M. G., "Bonding Uranium Carbide to Tantalum", AECU-4303 (May, 1959).

\section{Molybdenum}

\section{Constitution}

The ternary section shown in Figure 10 is based on statements by Phillips(1) and Nowrotny, Kieffer, and Benesovsky(2) to the effect that UC and $\mathrm{Mo}_{2} \mathrm{C}$ do not dissolve in one another, and by Bowman (3) to the effect that UC reacts with molybdenum to form $\mathrm{Mo}_{2} \mathrm{C}$.

The melting point of MoC is about $2650 \mathrm{C}$. It decomposes or transforms below about $1900 \mathrm{C}$.

Mo $2 \mathrm{C}$ decomposes peritectically at about $2400 \mathrm{C}$.

\section{Crystallography}

MoC: hexagonal (WC type), one molecule per unit cell, $a=2.901 \mathrm{~A}, c=2.768 \mathrm{~A}$; density $=8.5 \mathrm{~g}$ per $\mathrm{cm}^{3}$.

$\mathrm{Mo}_{2} \mathrm{C}$ : hep ( $\mathrm{W}_{2} \mathrm{C}$ type), one molecule per unit cell, $\mathrm{a}=2.994 \mathrm{~A}, \mathrm{c}=4.722 \mathrm{~A}$; density $=8.9 \mathrm{~g}$ per $\mathrm{cm}^{3}$. 


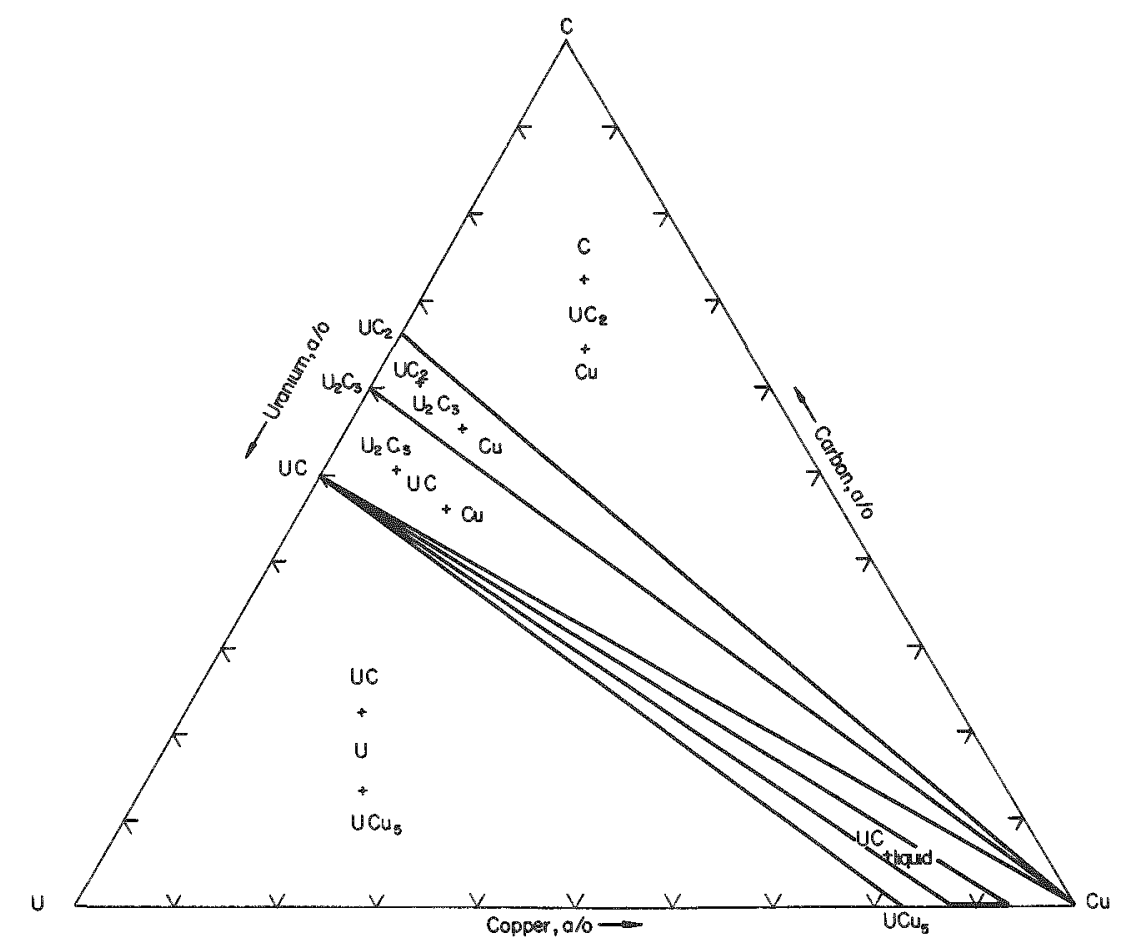

FIGURE 8. URANIUM-CARBON-COPPER TERNARY SECTION AT $1000 \mathrm{C}$

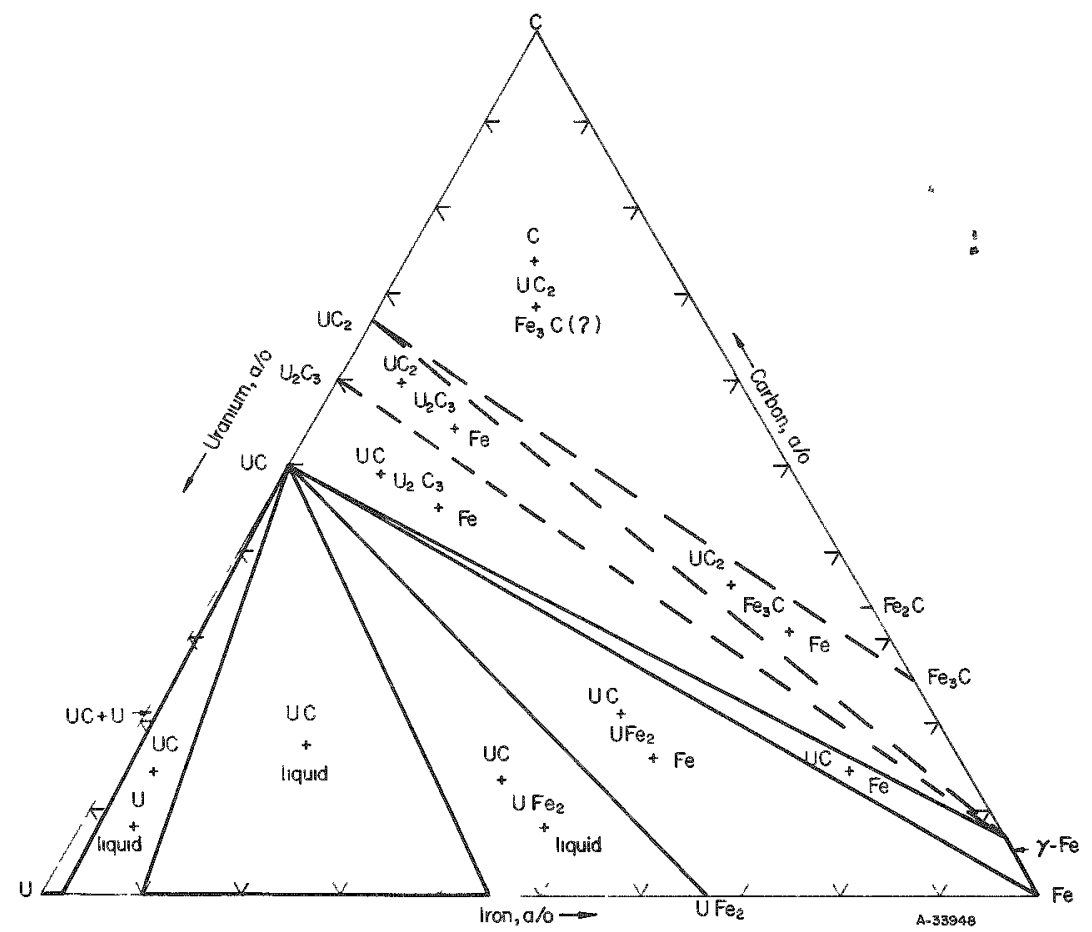

FIGURE 9. URANIUM-CARBON-IRON TERNARY SECTION AT $1000 \mathrm{C}$ 
$\underline{\text { References }}$

(1) Phillips, W. M. , BMI, Private Communication (November, 1959).

(2) Nowotny, H., Kieffer, R., and Benesovsky, F., "Preparation of UC and Its Relation to the Carbides of Refractory Transition Metals", Rev. met. , 55, 453-58 (May, 1958); see also Reference (4).

(3) Bowman, M. G., I.ASL, Private Communication (August, 1959).

(4) Nowotny, H., Kieffer, R., Benesovsky, F., and Laube, E., "Contribution to the Knowledge of the Partial Systems: UC with TiC, ZrC, $\mathrm{VC}, \mathrm{NbC}, \mathrm{TaC}, \mathrm{Cr}_{3} \mathrm{C}_{2}, \mathrm{Mo}_{2} \mathrm{C}$, and WC", Monatsh. Chem., 88, 336-43 (June, 1957).

Nicke1

\section{Constitution}

Bowman (I) reports that nickel may be added to UC to aid sintering at 2000 to $2200 \mathrm{C}$ and removed later by vacuum treatment at these temperatures. This would indicate a pseudobinary of the UC-chromium type between UC and nickel up to at least $2200 \mathrm{C}$.

Boettcher and Schneider(2) report that nickel reacts with UC at $1000 \mathrm{C}$ to form $\mathrm{U}_{6} \mathrm{Ni}$. Since $\mathrm{U}_{6} \mathrm{Ni}$ normally decomposes to liquid above $790 \mathrm{C}$, Boettcher and Schneider probably had a liquid layer in their sample at $1000 \mathrm{C}$.

$\mathrm{Ni}_{3} \mathrm{C}$ probably is stable only in a narrow temperature range from 2000 to $2500 \mathrm{C}$.

The uranium-carbon-nickel diagram at $1000 \mathrm{C}$ is presented in Figure 11.

Crystallography

$\mathrm{Ni}_{3} \mathrm{C}$ : orthorhombic ( $\mathrm{Fe}_{3} \mathrm{C}$ type); density $=7.96 \mathrm{~g} \mathrm{per} \mathrm{cm}^{3}$.

Ni6 $\mathrm{C}$ has been reported but may exist only as a ternary compound of the $\mathrm{Fe}_{3} \mathrm{~W}_{3} \mathrm{C}$ type.

\section{References}

(1) Bowman, M. G., "Bonding Uranium Carbide to Tantalum", AECU-4303 (May, 1959).

(2) Boettcher, A., and Schneider, G., "Some Properties of Uranium Monocarbide", Proceedings of the Second United Nations International Conference on the Peaceful Uses of Atomic Energy, Geneva (1958), Vol 6 , A/Conf. 15/P/964, pp 561-63. 


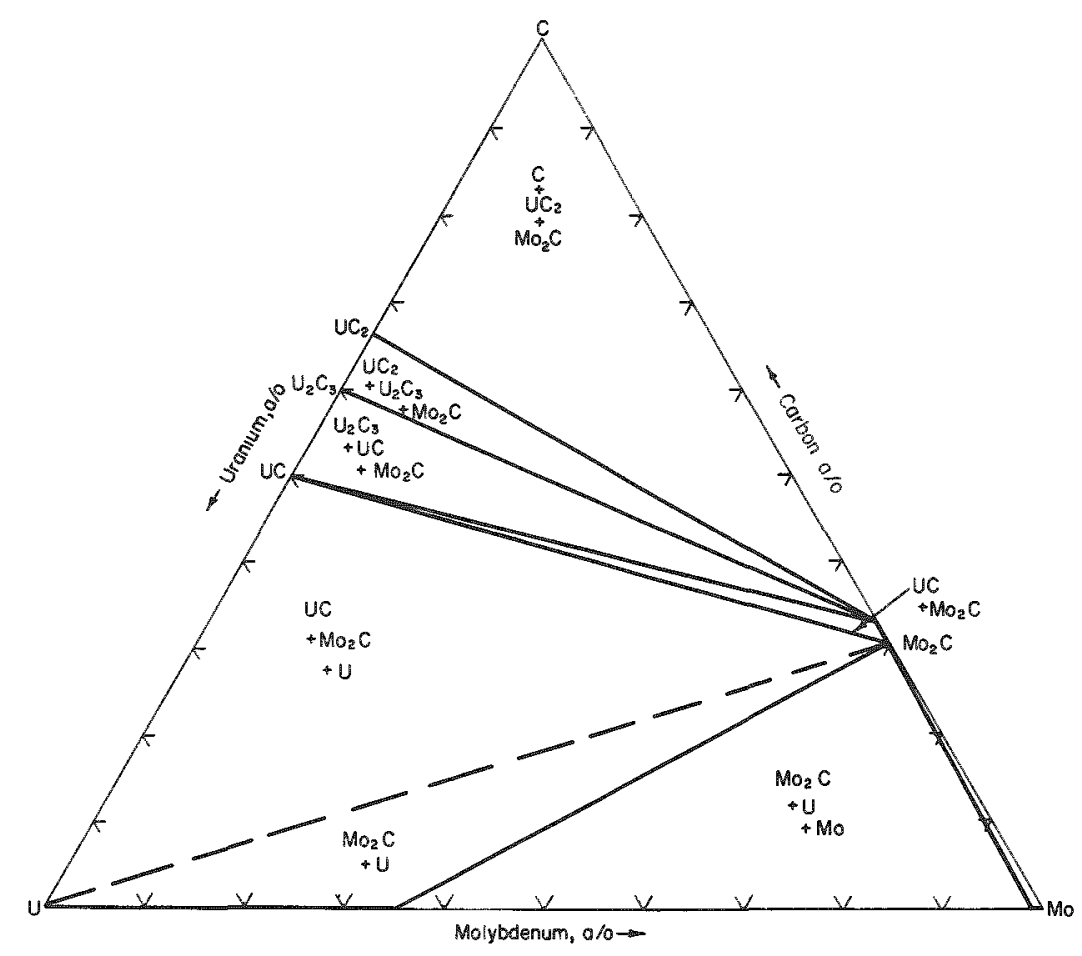

FIGURE 10. URANIUM-CARBON-MOLYBDENUM TERNARY SECTION AT $1000 \mathrm{C}$

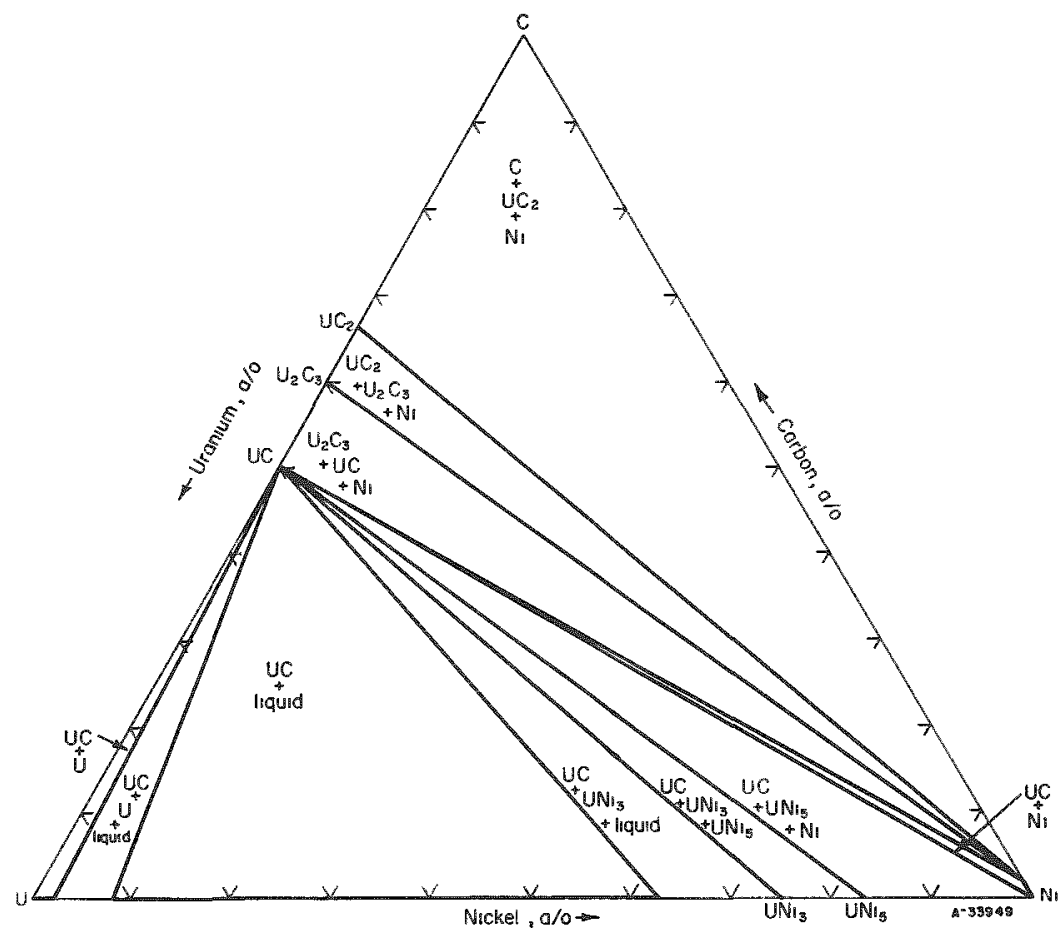

FIGURE 11. URANIUM-CARBON-NICKEL TERNARY SECTION AT $1000 \mathrm{C}$ 


\section{Niobium}

\section{Constitution}

The uranium-carbon-niobium diagram at $1000 \mathrm{C}$ is shown in Figure 12. The existence of complete solubility between $\mathrm{NbC}$ and $\mathrm{UC}$ has been established. $(1,2,3)$ Brownlee (1) reports that the liquidus of the pseudobinary system, UC-NbC, is a smooth curve between the terminal compositions, and that the melting point of $\mathrm{NbC}$ is $3485 \mathrm{C}$. Appreciable solubility of uranium in $\mathrm{Nb}_{2} \mathrm{C}$, analogous to the solubility of uranium in $\mathrm{Ta}_{2} \mathrm{C}$ is to be expected.

$\mathrm{Nb}_{2} \mathrm{C}$ decomposes peritectically at about $3260 \mathrm{C}$. (5) The melting point of $\mathrm{NbC}$ is about $3500 \mathrm{C}$.

\section{Crystallography}

$\mathrm{Nb}_{2} \mathrm{C}:$ hcp, $\mathrm{a}=3.117 \mathrm{~A}, \mathrm{c}=4.951 \mathrm{~A}$, one molecule per unit cell; density $=$ $7.9 \mathrm{~g}$ per $\mathrm{cm}^{3}$.

$\mathrm{NbC}$ : fcc ( $\mathrm{NaCl}, \mathrm{Bl}$ type), $\mathrm{a}=4.459 \mathrm{~A}$, four molecules per unit cell; density $=$ $7.82 \mathrm{~g}$ per $\mathrm{cm}^{3}$.

\section{References}

(1) Brownlee, L. D., "The Pseudo-Binary Systems of UC with ZrC, TaC, and $\mathrm{NbC} "$, J. Inst. Metals, 87, 58-61 (October, 1958).

(2) Nowotny, H., Kieffer, R., and Benesovsky, F., "Preparation of UC and its Relation to the Carbides of Refractory Transition Metals", Rev. met., 55, 453-58 (May, 1958); see also Reference (4).

(3) Roof, R. B., and Lombardo, J. J., "A Pseudo-Binary in the U-Nb-C System", Trans. AIME, 212, 50 (February, 1958).

(4) Nowotny, $H_{0}$, Kieffer, R., Benesovsky, F., and Laube, E., "Contribution to the Knowledge of the Partial Systems: UC with TiC, ZrC, VC, $\mathrm{NbC}, \mathrm{TaC}, \mathrm{Cr}_{3} \mathrm{C}_{2}, \mathrm{Mo}_{2} \mathrm{C}$, and WC", Monatsh. Chem., 88, $336-43$ (June, 1957).

(5) Pochon, M. L., McKinsey, C. R., Perkins, R. A., and Foreng, W. D., "Solubility of Carbon and Structure of Carbide Phases in $\mathrm{Ta}$ and $\mathrm{Nb}$ ", AIME Reactive Metals Conference, Buffalo, May 1958, Reactive Metals, Interscience Publishers, New York (1960). 


\section{Nitrogen}

\section{Constitution}

The existence of complete solubility between UN and UC has been established. $(1,2,3)$ The existence of extensive solutions between $U_{2} \mathrm{C}_{3}$ and $\mathrm{U}_{2} \mathrm{~N}_{3}$ and betwreen $\mathrm{UC}_{2}$ and $\mathrm{UN}_{2}$ is considered likely. The pressure of nitrogen over UN reaches $1 \mathrm{~atm}$ at a temperature between $2300 \mathrm{C}$ and its melting point, $2630 \mathrm{C}$. It has been found that $\mathrm{U}_{2} \mathrm{~N}_{3}$ decomposes peritectoidally at 1300 to $1550 \mathrm{C}$. The $\mathrm{UN}_{2}$ compound can be prepared only at high pressures. A ternary section is shown in Figure 13.

\section{Crystallography}

UN: fcc (NaCl, Bl type), $a=4.880 \mathrm{~A}$, four molecules per unit cell; density =

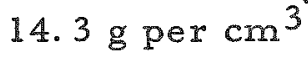

$\mathrm{U}_{2} \mathrm{~N}_{3}:$ bcc, $a=10.678 \mathrm{~A} ;$ density $=11.24 \mathrm{~g}$ per $\mathrm{cm}^{3}$

$\mathrm{UN}_{2}:$ fcc (CaF2, CI type), $a=5.31 \mathrm{~A}$; density $=11.73 \mathrm{~g}$ per $\mathrm{cm}^{3}$.

\section{$\underline{\text { References }}$}

(1) Rundle, R. E., Baenziger, N. C., Wilson, A. S., and McDonald, R. A., "The Structures of the Carbides, Nitrides, and Oxides of Uranium", J. Am. Chem. Soc., 70, 99-105 (1948).

(2) Austin, A. E., and Gerds, A. F., "The Uranium-Nitrogen-Carbon System", BMI-1272 (June, 1958).

(3) Williams, J., and Sambel1, R.A.J., "The Uranium MonocarbideUranium Mononitride System", J. Less Common Metals, 1, 217-26 (June, 1959).

\section{Oxygen}

Uranium monocarbide reacts with uranium dioxide to produce uranium metal and carbon monoxide in a vacuum at detectable rates at temperatures above $1300 \mathrm{C}$. At pressures near atmospheric, uranium monocarbide and uranium dioxide are stable in contact with one another to about $1800 \mathrm{C}$. Molten uranium monocarbide reacts with uranium dioxide at pressures near atmospheric, rejecting the oxygen as carbon dioxide so that generally less than $200 \mathrm{ppm}$ of oxygen is found in the solidified ingot.

The phase once identified as a solid solution of UC and UO(1) is believed on the basis of recent observations (2) to have been a solid solution of UC and UN. 


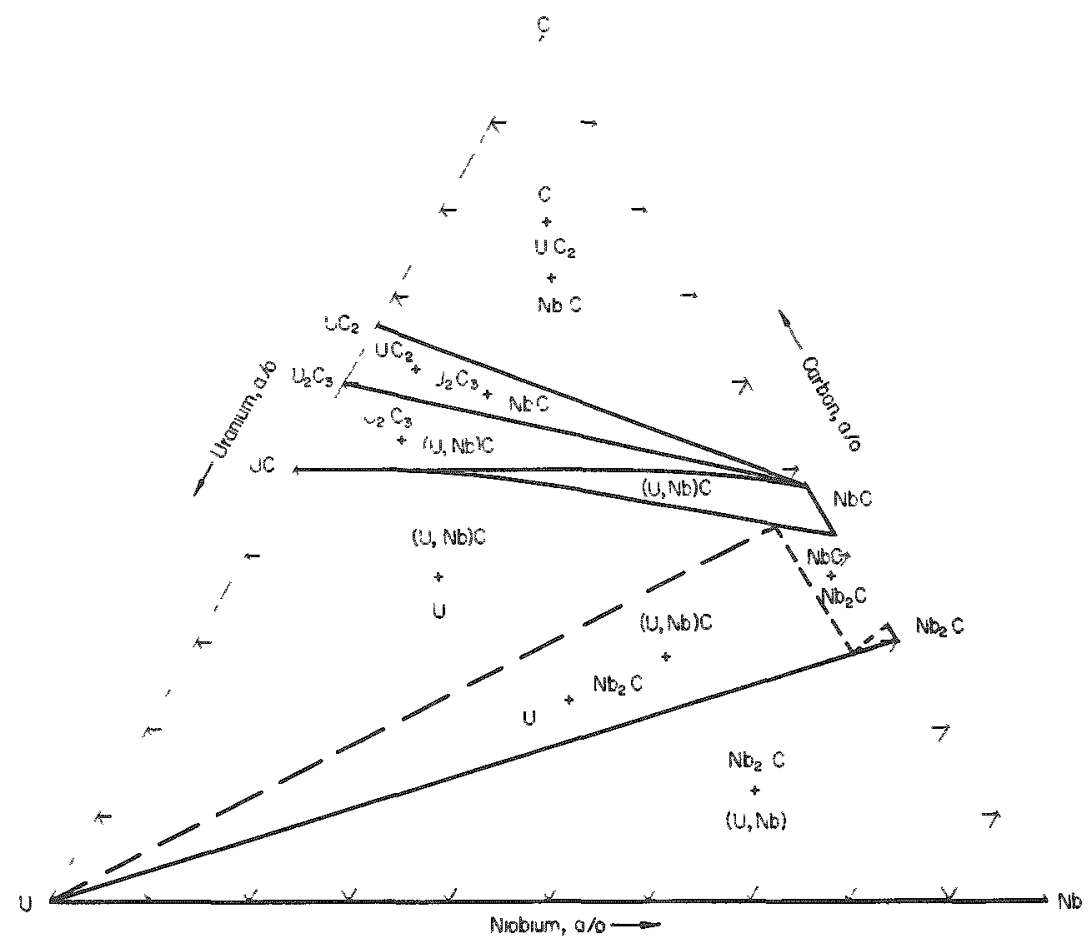

FIGURE 12. URANIUM-CARBON-NIOBIUM TERNARY SECTION AT $1000 \mathrm{C}$

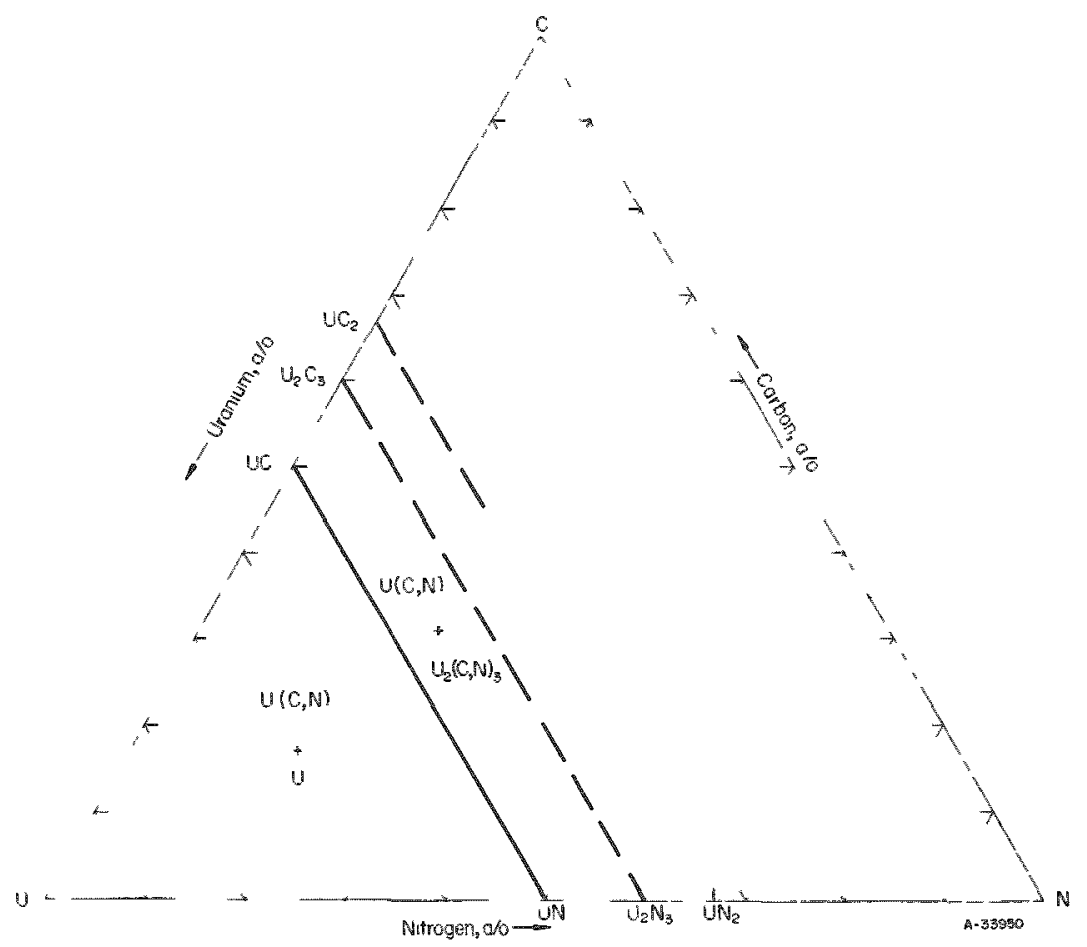

EIGURE 13. URANIUM-CARBON-NITROGEN TERNARY SECTION AT $1000 \mathrm{C}$ 


\section{References}

(1) Vaughan, D. A., Melton, C. W., and Gerds, A. F., "Experiments on the Preparation of $\mathrm{UO}_{2-x}$ and UO", BMI-1175 (March 6, 1957).

(2) Keh1, G. L., Mendel, E., F. [sic], E. J., Mueller, M. H., "Metallographic Identification of Inclusions in Uranium", Trans. ASM, 51, 717-35 (1959).

\section{Plutonium}

\section{Constitution}

The existence of complete solubility between PuC and UC has been suggested(I); and extensive solid solubility between $\mathrm{Pu}_{2} \mathrm{C}_{3}$ and $\mathrm{U}_{2} \mathrm{C}_{3}$ is to be expected.

PuC decomposes peritectically between 1200 and $1850 \mathrm{C}$.

$\mathrm{Pu}_{2} \mathrm{C}_{3}$ melts at about $1900 \mathrm{C}$.

A higher caxbide, near 67 a/o carbon, melts at about $2200 \mathrm{C}$.

The uranium-carbon-plutonium diagram at $1000 \mathrm{C}$ appears in Figure 14.

\section{Crystallography}

PuC: fcc (NaCl, Bl type), a = 4.97 A, four molecules per unit cell; density = $13.6 \mathrm{~g}$ per $\mathrm{cm}^{3}$.

$\mathrm{Pu}_{2} \mathrm{C}_{3}$ : bcc (space group $\overline{I 4} 3 \mathrm{~d}$ ), a $=8.13 \mathrm{~A}$, eight molecules per unit cell; density $=12.7 \mathrm{~g}$ per $\mathrm{cm}^{3}$.

\section{Reference}

(1) Nowotny, H., Kieffer, R., and Benesovsky, F., "Preparation of UC and its Relation to the Carbides of Refractory Transition Metals", Rev. met., 55, 453-58 (May, 1958).

\section{$\underline{\text { Rhenium }}$}

\section{Constitution}

Bowman (1) has reported that UC and rhenium do not dissolve in one another but produce a simple eutectic at $1850 \mathrm{C}$. This would imply a pseudobinary between UC and rhenium, but no diagram has been constructed. 


\section{Crystallography} $1600 \mathrm{C}$.

Carbides of rhenium, if they exist, are relatively unstable and do not form above

\section{Reference}

(1) Bowman, M. G., LASL, Private Communication (August, 1959).

\section{Silicon}

\section{Constitution}

According to Boettcher and Schneider(1), silicon reacts with UC at $1000 \mathrm{C}$ to form USiz.

Ivanov and Badayeva(2) report no solubility between UC and SiC.

SiC decomposes by a peritectic reaction between 2200 and $2700 \mathrm{C}$.

A uranium-carbon-silicon ternary section is shown in Figure 15.

\section{Crystallography}

SiC has many polymorphic forms. Beta SiC: fcc, $a=4.359 \mathrm{~A}$; density $=$ $3.2 \mathrm{~g}$ per $\mathrm{cm}^{3}$.

\section{References}

(1) Boettcher, A., and Schneider, G., "Some Properties of Uranium Monocarbide", Proceedings of the Second United Nations International Confer ence on the Peaceful Uses of Atomic Energy, Geneva (1958), Vol 6, A/Conf. 15/P/964, pp 561-63.

(2) Ivanov, O. S., and Badayeva, T. A., "Phase Diagrams of Certain Uranium and Thorium Systems", Proceedings of the Second United Nations International Conference on the Peaceful Uses of Atomic Energy, Geneva (1958), Vol 6, A/Conf. 15/P/2043, p 139.

\section{Tantalum}

\section{Constitution}

The existence of a continuous solid solution between TaC and UC has been established. $(1-4)$. Brownlee(4) and Bowman $(2)$ report that the liquidus of the pseudobinary system, UC-TaC, is a smooth curve between the terminal compositions. Brownlee gives the melting point of TaC as $3780 \mathrm{C}$. Bowman (2) found that tantalum displaces 


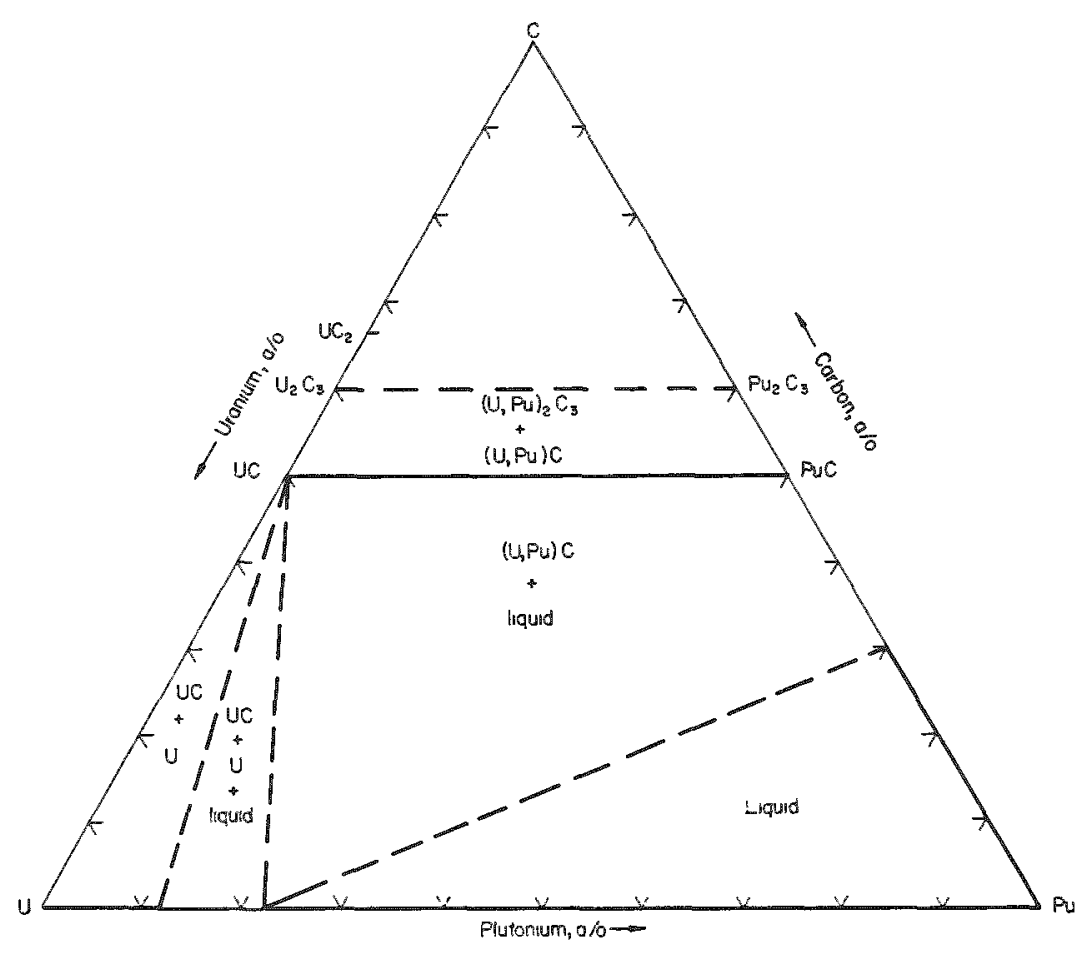

FIGURE 14. URANIUM-CARBON-PLUTONIUM TERNARY SECTION AT $1000 \mathrm{C}$

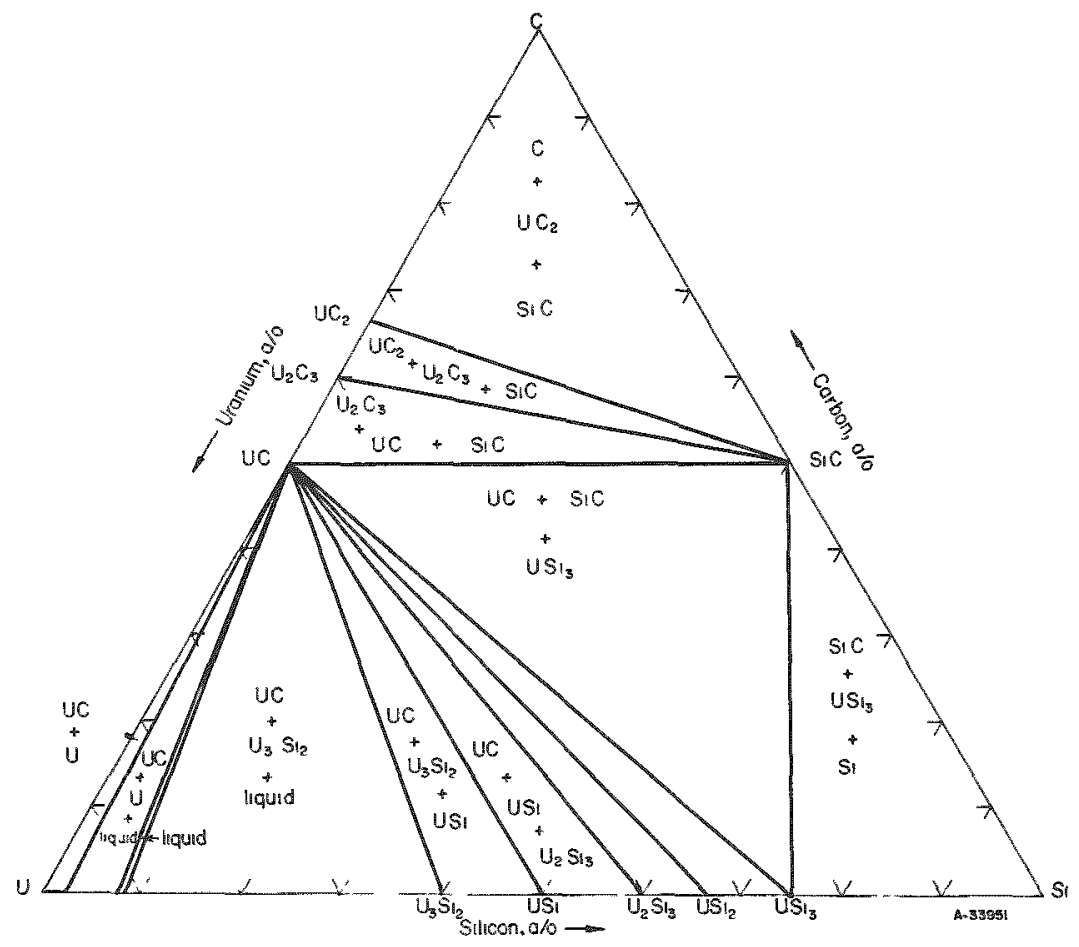

FIGURE 15. URANIUM-CARBON-SILICON TERNARY SECTION AT $1000 \mathrm{C}$ 
uranium from uranium carbide at increasingly rapid rates at temperatures above $1800 \mathrm{C}$. He successfully retarded this reaction (forming liquid uranium) by introducing layers of $\mathrm{TaC}$ and $\mathrm{Ta}_{2} \mathrm{C}$ between the tantalum and the UC. Parthe and Pemsler(1) state that there are no ternary compounds in the uranium-carbon-tantalum system at less than 50 a/o carbon, and that the only three-phase field in this region involves $\mathrm{Ta}_{2} \mathrm{C}$, the face-centered-cubic $(\mathrm{Ta}, \mathrm{U}) \mathrm{C}$ solution, and a body-centered-cubic metal, either uranium or tantalum. Apparently, they regarded tantalum and uranium as a single phase because they are structurally isomorphous. Some solubility of uranium in $\mathrm{Ta}_{2} \mathrm{C}$ is indicated, but the extent is unknown. (1)

The ternary sections shown in Figures 16 and 17 are based on the above statements. The section shown at $2000 \mathrm{C}$ is regarded as typical of most uranium-carbon ternary constitution diagrams above the melting point of uranium.

The melting point of $\mathrm{TaC}$ is about $3800 \mathrm{C}$.

$\mathrm{Ta}_{2} \mathrm{C}$ decomposes peritectically at about $3400 \mathrm{C}$.

\section{Crystallography}

TaC: fcc ( $\mathrm{NaCl}, \mathrm{Bl}$ type), $\mathrm{a}=4.446 \mathrm{~A}$, four molecules per unit cell; density $=$ $14.48 \mathrm{~g}$ per $\mathrm{cm}^{3}$.

Ta 2 C: hexagonal (C27 type), $a=3.09 \mathrm{~A}, c=4.93 \mathrm{~A}$, one molecule per unit cell; density $=15.1 \mathrm{~g}$ per $\mathrm{cm}^{3}$.

\section{$\underline{\text { References }}$}

(1) Parthe, E., and Pemsler, J. P., "Note on the Existence of 'UTa ${ }_{10} \mathrm{C}_{4}$ "," Trans. AIME, 215, 1070 (December, 1959).

(2) Bowman, M. G., "Bonding Uranium Carbide to Tantalum", AECU-4303 (May, 1959).

(3) Nowotny, H., Kieffer, R., and Benesovsky, F., "Preparation of UC and its Relation to the Carbides of Refractory Transition Metals", Rev. met., 55, 453-58 (May, 1958); see also Reference (5).

(4) Brownlee, L. D., "The Pseudo-Binary Systems of UC with ZrC, TaC, and $\mathrm{NbC"}$ " J. Inst. Metals, 87, 58-61 (October 1958).

(5) Nowotny, H., Kieffer, R., Benesovsky, F., and Laube, E., "Contribution to the Knowledge of the Partial Systems: UC with TiC, $\mathrm{ZrC}, \mathrm{VC}$, $\mathrm{NbC}, \mathrm{TaC}, \mathrm{Cr}_{3} \mathrm{C}_{2}, \mathrm{Mo}_{2} \mathrm{C}$, and WC", Monatsh. Chem., 88, 336-43 (June, 1957). 


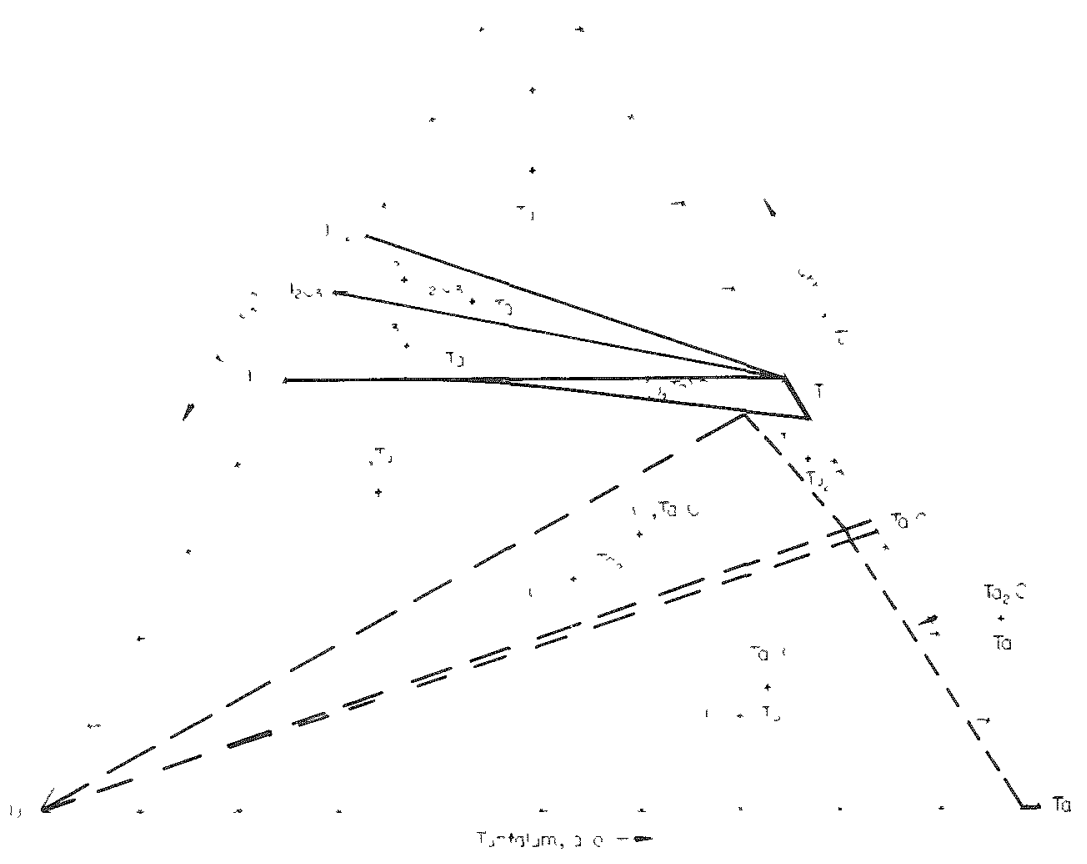

FIGURE 16. URANIUM-CARBON-TANTALUM TERNARY SECTION AT 1000 C

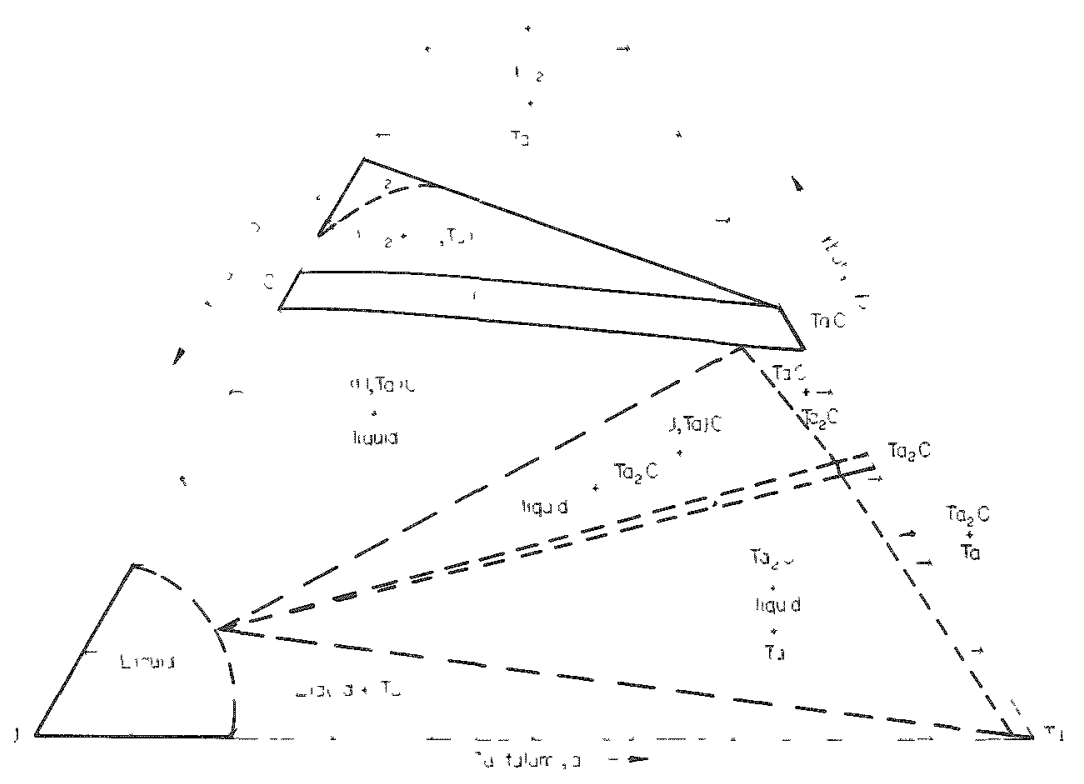

FIGURE 17. URANIUM-CARBON-TANTALUM TERNARY SECTION AT $2000 \mathrm{C}$ 
Thuliury

\section{Constitution}

The existence of complete solubility between ThC and UC has been established. (1-4) Ivanov and Badayeva(1) report that the re is complete solubility between ThC and UC, that thorium dissolves about 10 a/o carbon, and that thorium reacts with UC to produce uranium plus (Th, U)C. They found that between UC and thorium, the two-phase region, $(U, T h) C+$ uranium, exists up to 40 a/o thorium, the three-phase region, $(U, T h) C+$ uranium thorium, exists between 40 and 81 a/o thorium, and the two-phase region, uranium thorium, exists above 81 a/o thorium. The section shown in Figure 18 is based on these data. Brett, Law, and Iivey(2) suggest a polymorphic transition in $\mathrm{ThC}_{2}$ (probably similar to that in $\mathrm{UC}_{2}$ ) which results in complete solubility between $\mathrm{UC}_{2}$ and $\mathrm{ThC}_{2}$ above $1900 \mathrm{C}$, but which may produce immiscibility below $1900 \mathrm{C}$.

The melting point of ThC is about $2620 \mathrm{C}$.

The melting point of $\mathrm{ThC}_{2}$ is about $2660 \mathrm{C}$.

\section{Crystallography}

ThC: fec (NaCl, Bl type), a $=5.34 \mathrm{~A}$, four molecules per unit cell; density =

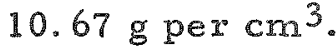

$\mathrm{ThC}_{2}$ : monoclinic, $\mathrm{a}=6.53 \mathrm{~A}, \mathrm{~b}=4.24 \mathrm{~A}, \mathrm{c}=6.56 \mathrm{~A}, \beta=104^{\circ}$, four molecules per unit cell; density $=9.6 \mathrm{~g}^{\text {per }} \mathrm{cm}^{3}$.

\section{References}

(1) Ivanov, O., and Badayeva, T., "Phase Diagrams of Certain Uranium and Thorium Systems", Proceedings of the Second United Nations International Conference on the Peaceful Uses of Atomic Energy, Geneva (1958), Vol 6, A/Conf. 15/P/2043, p 139.

(2) Brett, N., Law, O., and Livey, D. T., "Some Investigations of the U:Th:C System", AERE-M/R-2574 (June, 1958).

(3) Nowotny, H., Kieffer, R., Benesovsky, F., and Laube, E., "Note on the Partial System UC-ThC", Planseeber. Pulvermet., 5, 102-3 (December, 1957).

(4) Cirilli, V., and Brisi, C., "Solid Solutions Between UC and ThC", Ricerca sci., 28, 1431-34 (July, 1958). 


\section{Titanium}

\section{Constitution}

Nowotny, Kieffer, and Benesovsky(1) report that UC dissolves less than 10 mole per cent of TiC and that TiC dissolves about 20 mole per cent of UC. Phillips $(2)$ suggests a eutectic between UC and TiC at about 12 mole per cent, and no solubility of titanium metal in UC.

The melting point of $\mathrm{TiC}$ is about $3200 \mathrm{C}$.

The uranium-carbon-titanium diagram at $1000 \mathrm{C}$ is shown in Figure 19.

\section{Crystallography}

TiC: fcc (NaCl, B1 type), a = 4.32 A, four molecules per unit cell; density = $4.25 \mathrm{~g}$ per $\mathrm{cm}^{3}$.

\section{$\underline{\text { References }}$}

(1) Nowotny, H., Kieffer, R., and Benesovsky, F., "Preparation of UC and its Relation to the Carbides of Refractory Transition Metals", Rev. met., 55, 453-58 (May, 1958); see also Reference (3).

(2) Phillips, W. M., BMI, Private Communication (November, 1959).

(3) Nowotny, H., Kieffer, R., Benesovsky, F., and Laube, E., "Contribution to the Knowledge of the Partial Systems: UC with TiC, ZrC, VC, $\mathrm{NbC}, \mathrm{TaC}, \mathrm{Cr}_{3} \mathrm{C}_{2}, \mathrm{Mo}_{2} \mathrm{C}$, and WC", Monatsh. Chem, $88,336-43$ (June, 1957).

\section{Tungsten}

\section{Constitution}

Newkirk and Bates(1) observed that UC in contact with tungsten melted at $2280 \mathrm{C}$.

Nowotny, Kieffer, and Benesovsky(2) report that UC dissolves about 10 mole per cent WC, but that WC dissolves no UC.

$\mathrm{W}_{2} \mathrm{C}$ melts at about $2800 \mathrm{C}$.

WC melts at about $2800 \mathrm{C}$.

The uranium-carbon-tungsten diagram at $1000 \mathrm{C}$ is shown in Figure 20. 


\section{Crystallography} per $\mathrm{cm}^{3}$.

$W_{2} \mathrm{C}: \mathrm{hcp}, \mathrm{a}=2.99 \mathrm{~A}, \mathrm{c}=4.72 \mathrm{~A}$, one molecule per unit cell; density $=17.2 \mathrm{~g}$

WC: hexagonal, $a=2.90 \mathrm{~A}, c=2.83 \mathrm{~A}$, one molecule per unit cell; density $=$ $15.5 \mathrm{~g}$ per $\mathrm{cm}^{3}$.

\section{$\underline{\text { References }}$}

(1) Newkirk, H. W., and Bates, J. L., "The Melting Points of $\mathrm{UO}_{2}$, UC, and UN', HW-59468 (March, 1959).

(2) Nowotny, H., Kieffer, R., and Benesovsky, F., "Preparation of UC and its Relation to the Carbides of Refractory Transition Metals", Rev. met., 55, 453-58 (May, 1958); see also Reference (3).

(3) Nowotny, H., Kieffer, R., Benesovsky, F., and Laube, E., "Contribution to the Knowledge of the Partial Systems: UC with TiC, ZrC, VC, $\mathrm{NbC}, \mathrm{TaC}, \mathrm{Cr}_{3} \mathrm{C}_{2}, \mathrm{Mo}_{2} \mathrm{C}$, and WC", Monatsh. Chem., 88, 336-43 (June, 1957).

\section{Vanadium}

\section{Constitution}

Nowotny, Kieffer, and Benesovsky(1) report that UC dissolves about 20 mole per cent of VC and that VC dissolves practically no UC.

$\mathrm{V}_{2} \mathrm{C}$ decomposes peritectically at a temperature above $1800 \mathrm{C}$.

The melting point of $\mathrm{VC}$ is about $2800 \mathrm{C}$.

A uranium-carbon-vanadium section is shown in Figure 21.

\section{Crystallography}

$\mathrm{V}_{2} \mathrm{C}: \mathrm{hcp}$ (L'3 type), $\mathrm{a}=2.906 \mathrm{~A}, \mathrm{c}=4.597 \mathrm{~A}$, one molecule per unit cell; density $=5.6 \mathrm{~g}$ per $\mathrm{cm}^{3}$.

VC: fcc (NaCl, Bl type), a $=4.17 \mathrm{~A}$, four molecules per unit cell; density $=$ $5.36 \mathrm{~g}$ per $\mathrm{cm}^{3}$. 


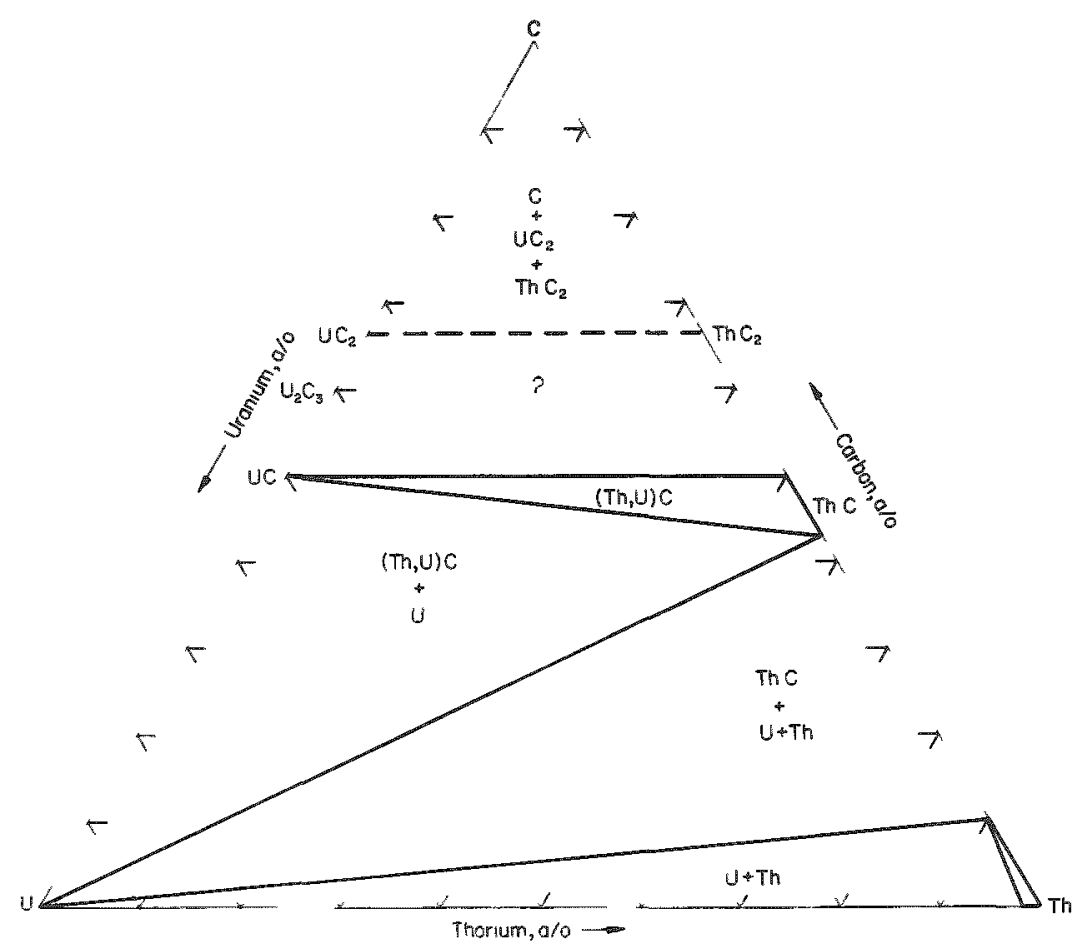

FIGURE 18. URANIUM-CARBON-THORIUM TERNARY SECTION AT $1000 \mathrm{C}$

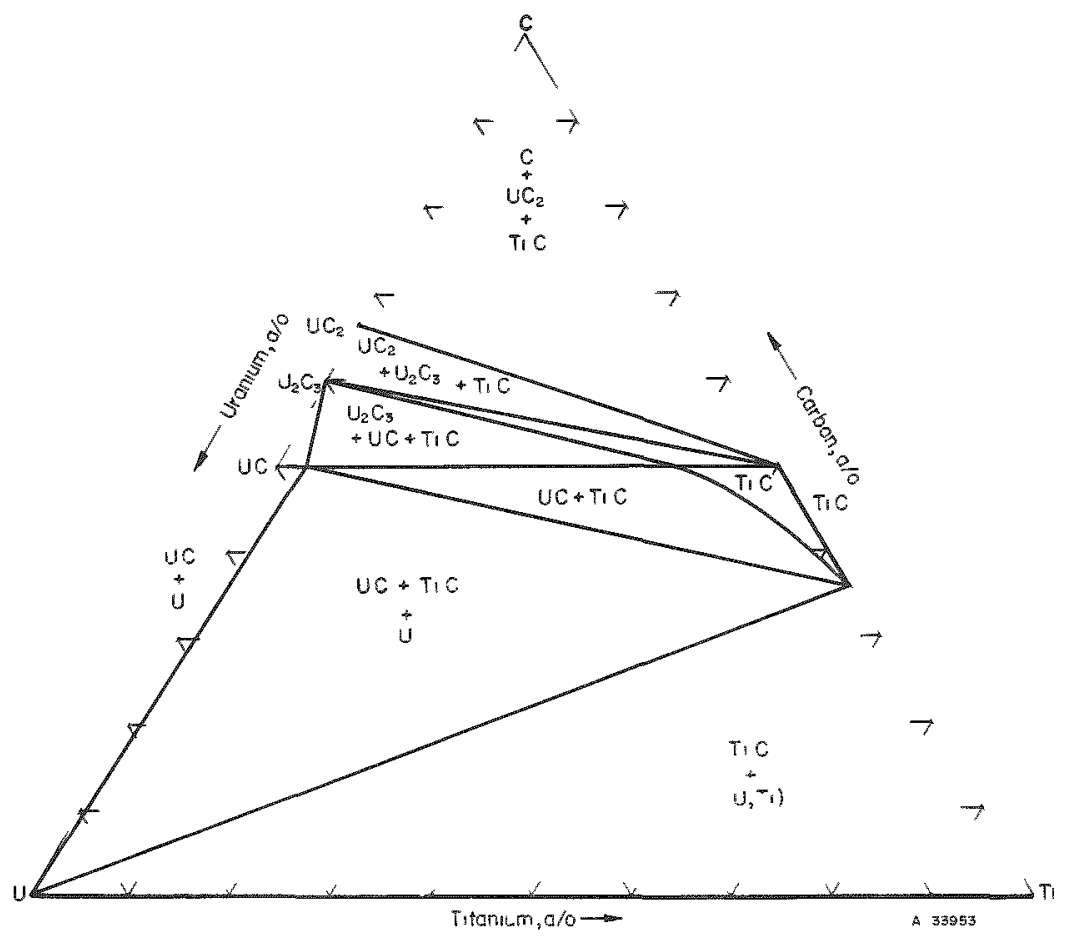

FIGURE 19. URANIUM-CARBON-TITANIUM TERNARY SECTION AT $1000 \mathrm{C}$ 


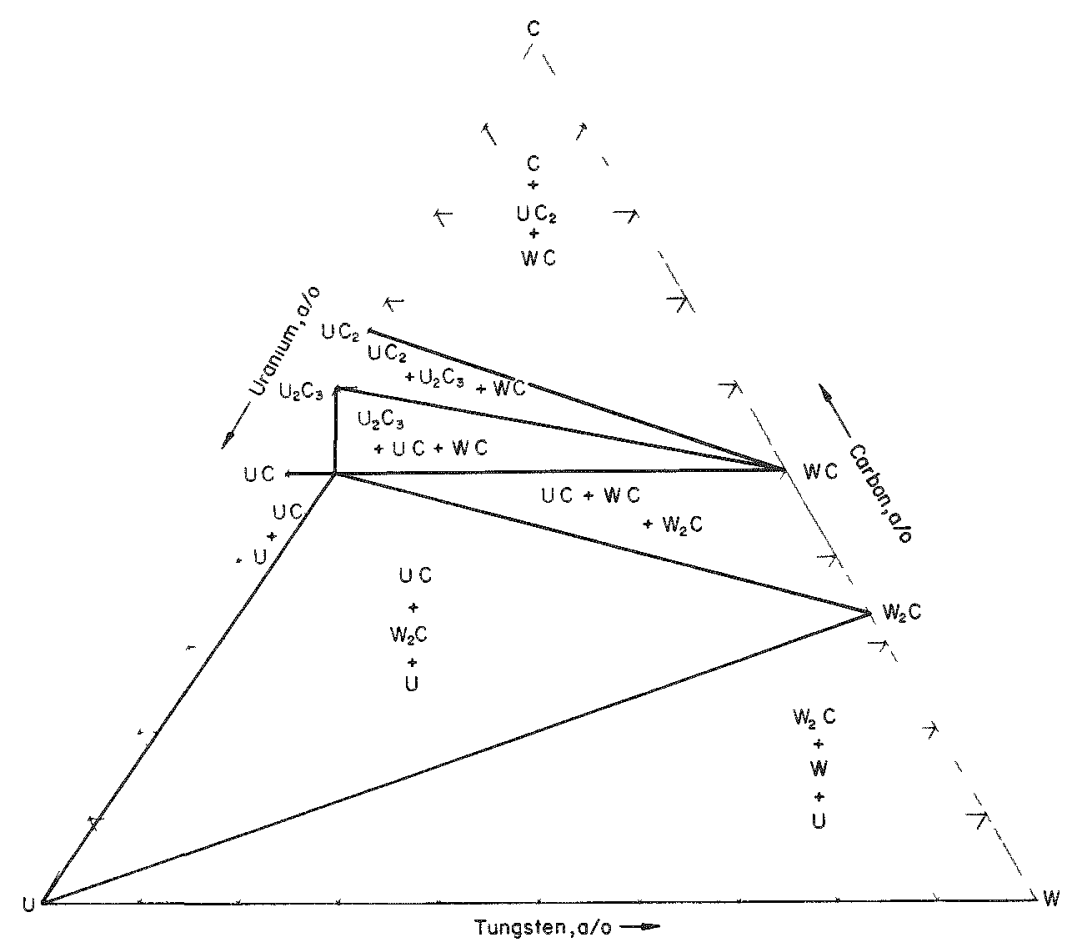

FIGURE 20. URANIUM-CARBON-TUNGSTEN TERNARY SECTION AT $1000 \mathrm{C}$

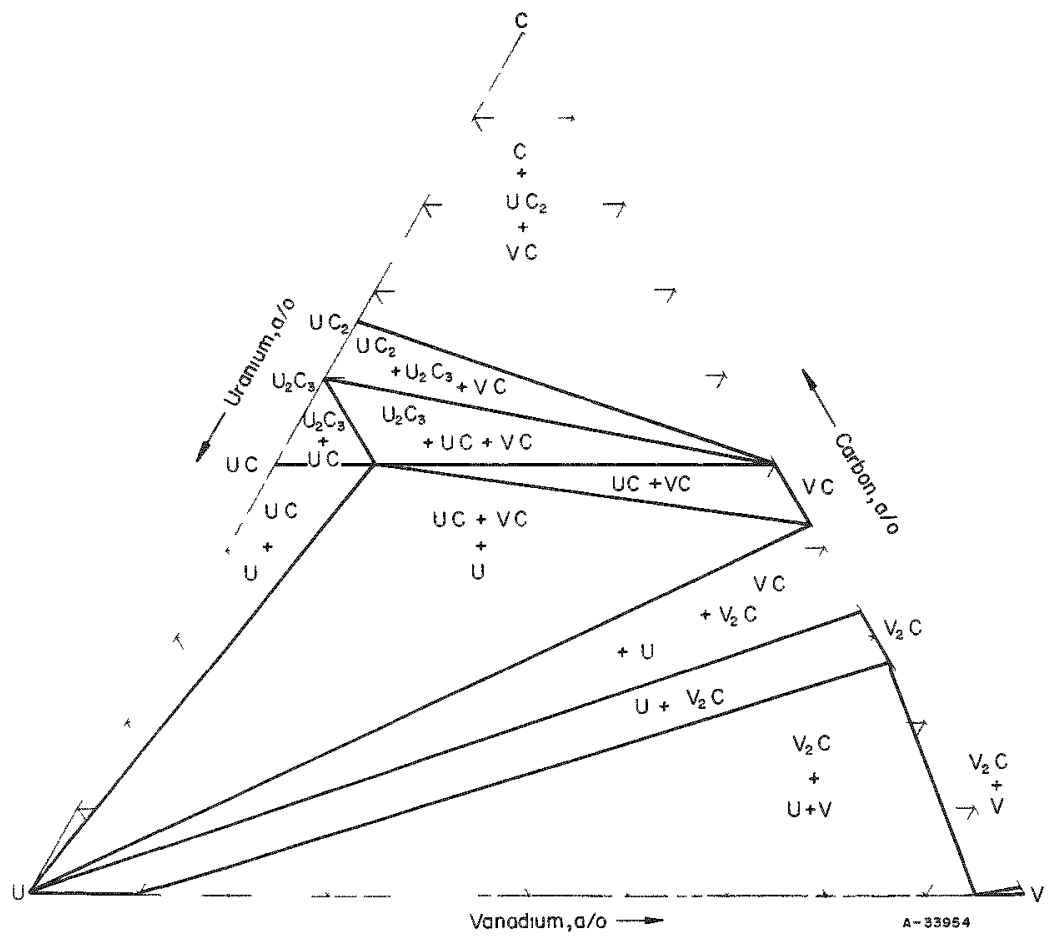

FIGURE 21. URANIUM-CARBON-VANADIUM TERNARY SECTION AT $1000 \mathrm{C}$ 


\section{References}

(1) Nowotny, H., Kieffer, R., and Benesovsky, F., "Preparation of UC and its Relation to the Carbides of Refractory Transition Metals", Rev. met., 55, 453-58 (May, 1958); see also Reference (2).

(2) Nowotny, H., Kieffer, R., Benesovsky, F., and Laube, E., "Contribution to the Knowledge of the Partial Systems: UC with TiC, ZrC, VC, $\mathrm{NbC}, \mathrm{TaC}, \mathrm{Cr}_{3} \mathrm{C}_{2}, \mathrm{Mo}_{2} \mathrm{C}$, and $\mathrm{WC}^{\prime \prime}$, Monatsh. Chem., 88, 336-43 (June, 1957).

\section{Zinc}

\section{Constitution}

Boettcher and Schneider (1) report that UC is wet by molten zinc.

\section{Reference}

(1) Boettcher, A., and Schneider, G., "Some Properties of Uranium Monocarbide", Proceedings of the Second United Nations International Confer ence on the Peaceful Uses of Atomic Energy, Geneva (1958), Vol 6, A/Conf. 15/P/964, pp 561-63.

\section{Zirconium}

\section{Constitution}

The existence of complete solubility between $\mathrm{ZrC}$ and UC has been established. (1-4) Brownlee(1) reports that the liquidus of the pseudobinary system, UC-ZrC, is a smooth curve between the terminal compositions, and that the meling point of $\mathrm{ZrC}$ is $3535 \mathrm{C}$.

The melting point of $\mathrm{ZrC}$ is about $3500 \mathrm{C}$.

A ternary section is presented in Figure 22.

\section{Crystallography}

ZrC: fcc (NaC1, B1 type), a = 4.687 A, four molecules per unit cell; density $=$ $6.9 \mathrm{~g}$ per $\mathrm{cm}^{3}$. 


\section{References}

(1) Brownlee, L. D., "The Pseudo-Binary Systems of UC with ZrC, TaC, and $\mathrm{NbC"}$, J. Inst. Metals, 87, 58-61 (October, 1958).

(2) Ivanov, O., and Badayeva, T., "Phase Diagrams of Certain Uranium and Thorium Systems", Proceedings of Second United Nations International Conference on Peaceful Uses of Atomic Energy", Geneva (1958), Vol 6, A/Conf. 15/P/2043, p 139.

(3) Nowotny, H., Kieffer, R., and Benesovsky, F., "Preparation of UC and its Relation to the Carbides of Refractory Transition Metals", Rev. met. 55, 453-58 (May, 1958); see also Reference (5).

(4) Witteman, W. G., Leitnaker, J. M., and Bowman, M. G., "The Solid Solubility of UC and ZrC", LA-2159 (April, 1958).

(5) Nowotny, H., Kieffer, R., Benesovsky, F., and Laube, E., "Contribution to the Knowledge of the Partial Systems: UC with TiC, ZrC, VC, $\mathrm{NbC}, \mathrm{TaC}, \mathrm{Cr}_{3} \mathrm{C}_{2}, \mathrm{Mo}_{2} \mathrm{C}$, and WC", Monatsh. Chem., 88, 336-43 (June, 1957).

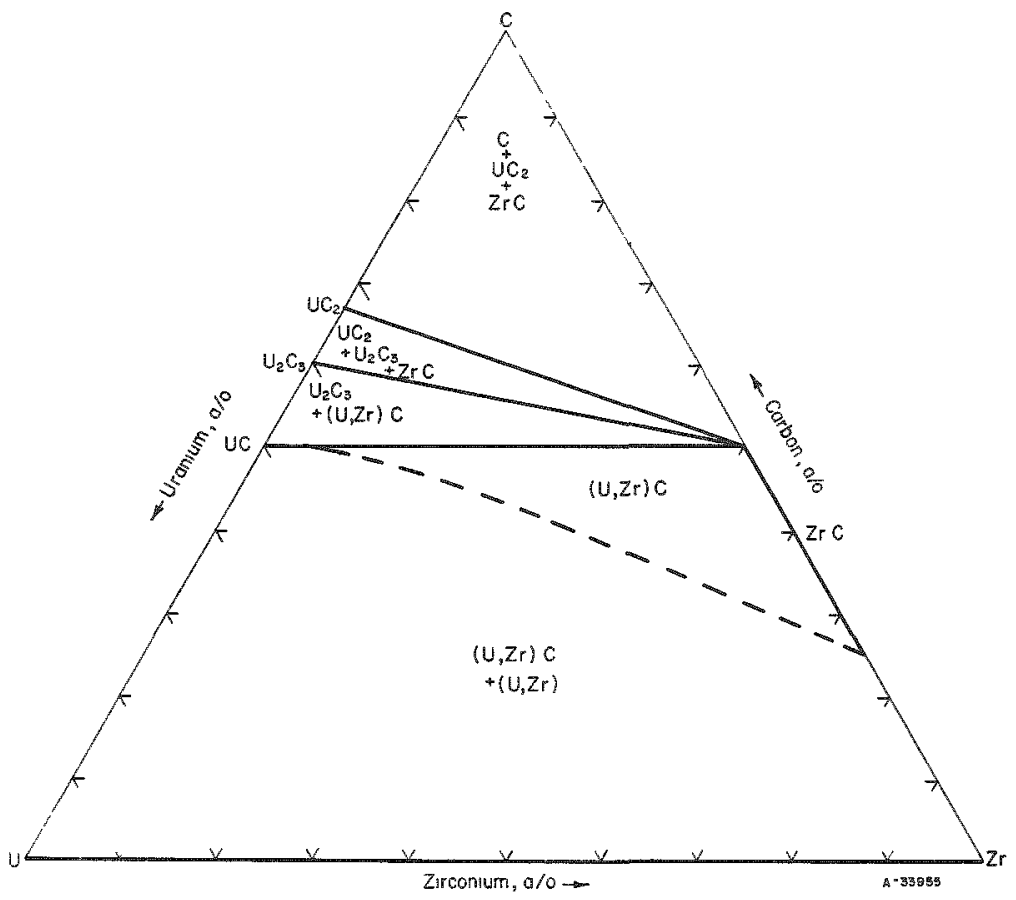

FIGURE 22. URANIUM-CARBON-ZIRCONIUM TERNARY SYSTEM AT $1000 \mathrm{C}$ 


\section{Constitution}

The melting points of $\mathrm{ThC}$ and $\mathrm{ThC}_{2}$ were found to be 2625 and $2655 \mathrm{C}$ by Wilhelm and Chiotti(1). The banded structure of $\mathrm{ThC}_{2}$ obtained by Wilhelm and Chiotti is identical to that produced in $\mathrm{UC}_{2}$ by transformation from the high-temperature cubic structure to the low-temperature form. Brett, Law, and Livey(2) suggest that $\mathrm{ThC}_{2}$ has a polymorphic transition at about $1900 \mathrm{C}$. The structure obtained by Wilhelm and Chiotti on cooling a thorium $-7.2 \mathrm{w} / 0$ carbon alloy from $2400 \mathrm{C}$ suggests that $\mathrm{ThC}$ and $\mathrm{ThC}_{2}$ are immiscible at this temperature. The structure obtained by Wilhelm and Chiotti on cooling a thorium $-6.1 \mathrm{w} / 0$ carbon alloy from $2615 \mathrm{C}$ is clearly a eutectic structure as postulated by their constitution diagram. The structure obtained on cooling a thorium $-8 \mathrm{w} / 0$ carbon alloy from $2655 \mathrm{C}$ is consistent with an eutectoid near $8 \mathrm{w} / 0$ carbon and $1900 \mathrm{C}$ resulting from the polymorphic transition suggested by Brett, Law, and Livey.

The existence of an allotropic transformation in thorium was discovered by Chiotti(3). This discovery of a transition from the low-temperature face-centeredcubic to the high-temperature body-centered-cubic structure has been confirmed, and the temperature of transformation has been established as about $1360 \mathrm{C}$. Wilhelm and Chiotti(1) found a region of single-phase solid solution at $2.6 \mathrm{w} / 0$ carbon and $1900 \mathrm{C}$ and indicated that this meant a region of solid solution between thorium and thorium carbide. While such a construction is not impossible, as Hansen and Anderko(4) point out, continuous solid solubility of carbon from the metallic face-centered-cubic structure of thorium, through the ionic ( $N a C l$ ) structure of $\mathrm{ThC}$, to the unknown (probably $\left.\mathrm{CaF}_{2}\right)$ high-temperature structure of $\mathrm{ThC}_{2}$ is not conceivable. Wilhelm and Chiotti(1) have apparently ignored a two-phase structure obtained at $4.1 \mathrm{w} / 0$ carbon and $2110 \mathrm{C}$ indicating that ThC has low solubility for thorium.

A possible constitution diagram based on the above data and suggestions has been constructed (Figure 23). The existence of a phase, $\mathrm{Th}_{2} \mathrm{C}_{3}$, similar to $\mathrm{U}_{2} \mathrm{C}_{3}$ has not been ruled out by the above investigations.

\section{Crystallography}

ThC: fcc ( $\mathrm{NaCl}, \mathrm{Bl}$ type), a = 5.34 A, four molecules per unit cell; density = $10.6 \mathrm{~g}_{\text {per }} \mathrm{cm}^{3}$.

$\mathrm{ThC}_{2}$ (below $1900 \mathrm{C}$ ): monoclinic, $\mathrm{a}=6.53 \mathrm{~A}, \mathrm{~b}=4.24 \mathrm{~A}, \mathrm{c}=6.56 \mathrm{~A}$, four molecules per unit cell; density $=9.6$ per $\mathrm{cm}^{3}$.

$\mathrm{ThC}_{2}$ (above $1900 \mathrm{C}$ ): structure unknown, probably face-centered cubic of the CaF2 type since Brett, Law, and Livey(2) suggest complete solubility above $1900 \mathrm{C}$ between $\mathrm{UC}_{2}$ and $\mathrm{ThC}_{2}$. 


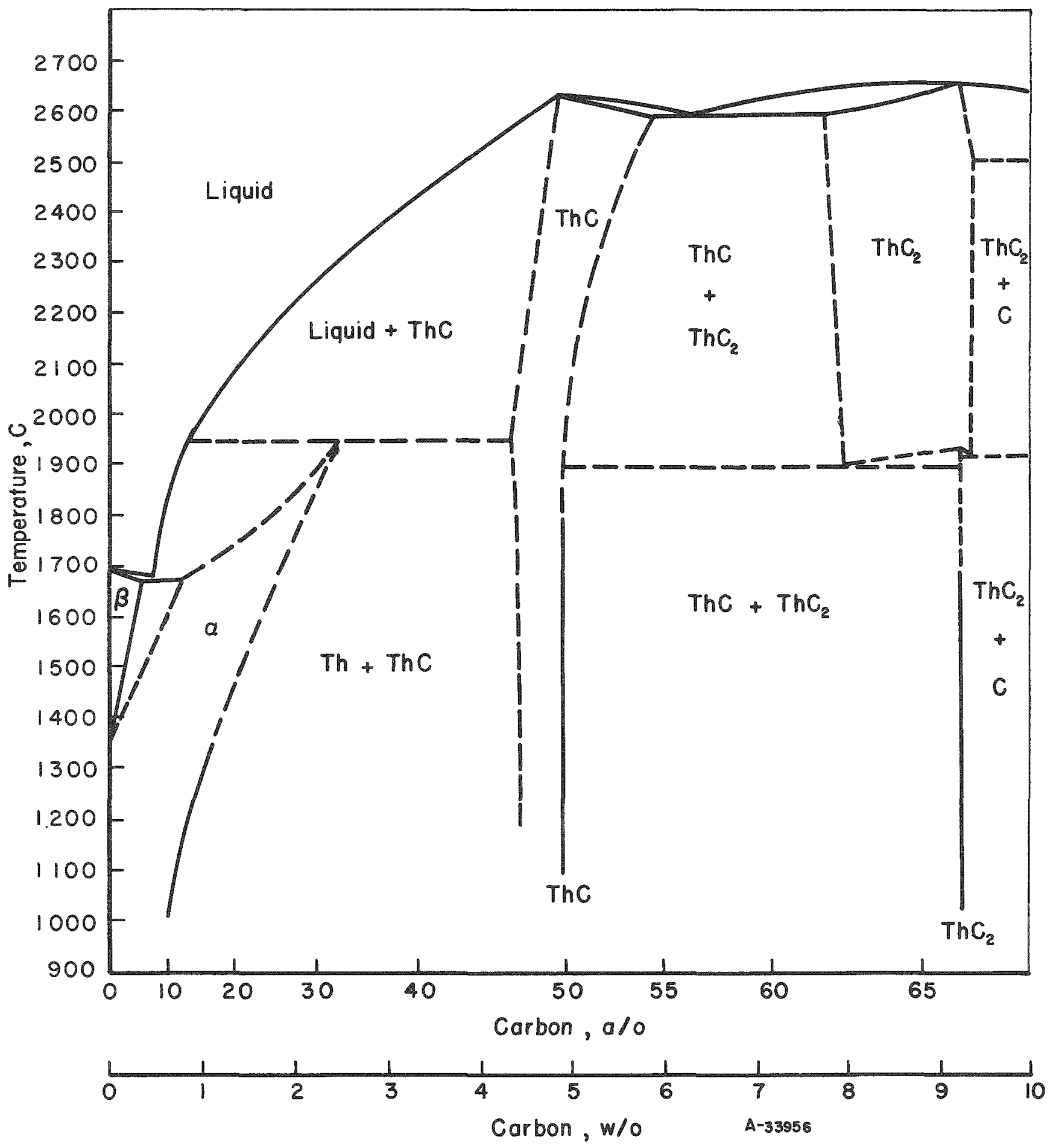

FIGURE 23. THORIUM-CARBON CONSTITUTIONAL DIAGRAM 
References

(1) Wilhelm, H. A., and Chiotti, P., "Thorium-Carbon System", Trans. ASM, 42, 1295-1310 (1950).

(2) Brett, N. , Law, D., and Livey, D. T., "Some Investigations of the U:Th:C System", AERE-M/R-2574 (June, 1958).

(3) Chiotti, P., "High-Temperature Crystal Structure of Thorium", J. Electrochem. Soc., 101, 567-570 (1954).

(4) Hansen, M. , and Anderko, K. , Constitution of Binary Alloys, McGraw-Hill Book Company, Inc., New York (1958), p 382.

\section{THORIUM-CARBON TERNARY SYSTEMS}

\section{Nitrogen}

\section{Constitution}

It has been reported by Scaife and Wylie (1) that one of the thorium nitrides (probably $\mathrm{ThN}$ ) is more stable than $\mathrm{ThC}_{2}$ below $2100 \mathrm{C}$.

The melting point of ThN is about $2600 \mathrm{C}$, and it is apparently stable in a vacuum at temperatures below $2000 \mathrm{C} .(2)$ It is known that $\mathrm{Th}_{2} \mathrm{~N}_{3}$ is not stable in a vacuum at $1500 \mathrm{C}$.

\section{Crystallography}

ThN: fcc ( $\mathrm{NaCl}, \mathrm{Bl}$ type), a $=5.21 \mathrm{~A}$, four molecules per unit cell; density = $11.6 \mathrm{~g}$ per $\mathrm{cm}^{3}$.

$\mathrm{Th}_{2} \mathrm{~N}_{3}$ : hexagonal, $\mathrm{a}=3.87 \mathrm{~A}, \mathrm{c}=6.16 \mathrm{~A}$, one molecule per unit cell; density $=$ $10.5 \mathrm{~g}_{\text {per }} \mathrm{cm}^{3}$.

\section{$\underline{\text { References }}$}

(1) Scaife, D. E., and Wylie, A. W., "The Preparation of $\mathrm{ThC}_{2}$ and some Aspects of the High Temperature Decontamination of Irradiated Carbide Fuels", Australian Atomic Energy Symposium (1958), "Section 1, High Temperature and Ceramics", pp 172-81.

(2) Chiotti, P., "Experimental Refractory Bodies of High Melting Nitrides, Carbides, and Uranium Dioxide", J. Am. Ceram. Soc, 35, pp 123-30 (May, 1952). 


\section{Oxygen}

Thorium monocarbide hydrolyses rapidly in moist air and tends to oxidize at room temperature. It should be stored in a dry, inert atmosphere.

Thorium metal has practically no solubility for oxygen, and it may be presumed that the same is true of the thorium carbides.

\section{Uranium}

Thorium-carbon-uranium compositions are discussed in the section on uraniumcarbon ternary systems.

\section{Zirconium}

\section{Constitution}

Thorium monocarbide is evidently a very poor solvent, for, according to Ivanov and Badayeva(1), it dissolves only 6 mole per cent of ZrC, which is one of the few monocarbides likely to dissolve in ThC. There is no solubility of ThC in $\mathrm{ZrC}$.

Murray (2) reports that zirconium reacts with carbon present in solution in thorium to form zirconium carbide.

The thorium-carbon-zirconium diagram at $1000 \mathrm{C}$ is shown in Figure 24.

\section{Crystallography}

ZrC: fcc ( $\mathrm{NaCl}, \mathrm{Bl}$ type), $\mathrm{a}=4.687 \mathrm{~A}$, four molecules per unit cell; density $=$

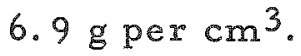

\section{References}

(1) Ivanov, O. S., and Badayeva, T. A., "Phase Diagrams of Certain Uranium and Thorium Systems", Proceedings of the Second United Nations International Conference on the Peaceful Uses of Atomic Energy, Geneva (1958), Vol 6, A/Conf. 15/P/2043, p 139.

(2) Murray, J. R., "The Constitution of Thorium-Zirconium Alloys Containing more than 15 Per Cent Zirconium", AERE-R-3048 (September, 1959). 


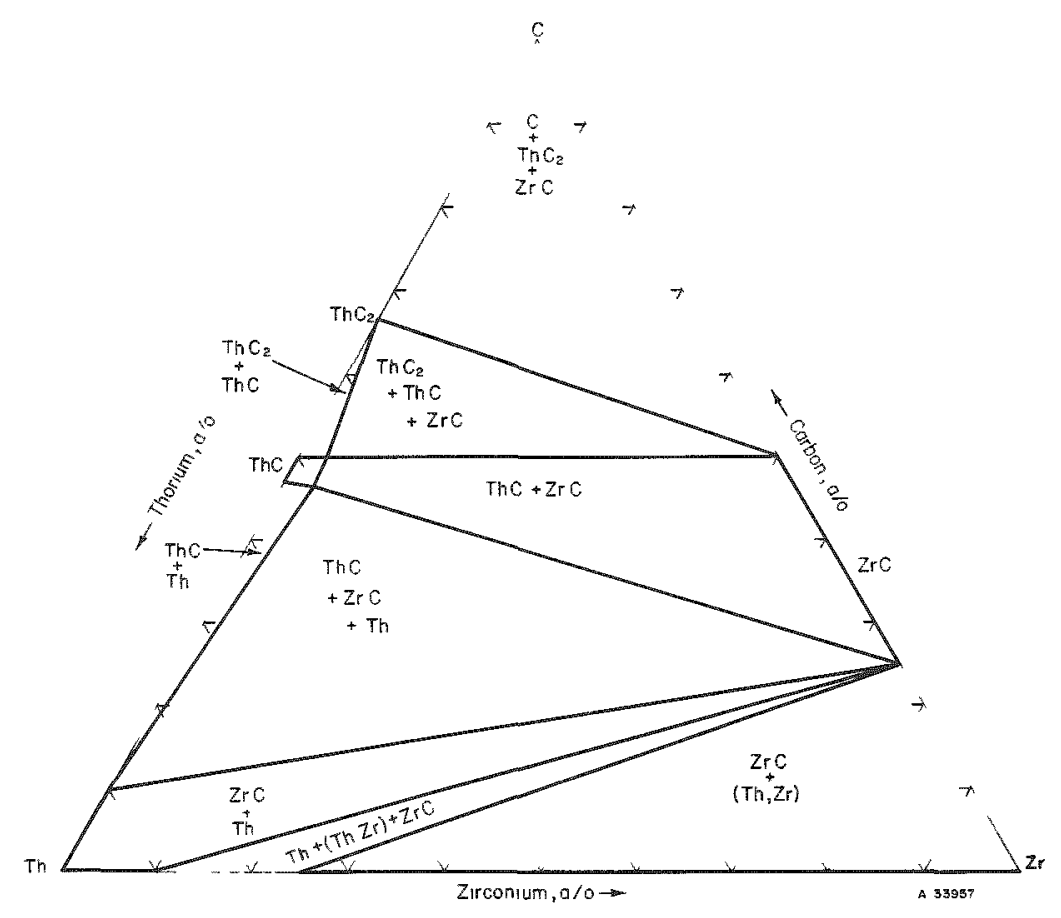

FIGURE 24. THORIUM-CARBON-ZIRCONIUM TERNARY SECTION AT $1000 \mathrm{C}$

\section{THE PLUTONIUM-CAR BON BINARY SYSTEM}

\section{Constitution}

The plutonium-carbon constitutional diagram is shown in Figure 25. The melting points of PuC and $\mathrm{Pu}_{2} \mathrm{C}_{3}$ were found by Drummond, McDonald, Ockenden, and Welch(1) to be about 1850 and $1900 \mathrm{C}$, respectively. Drummond, et al., found an additional substance containing from 8.5 to $9.5 \mathrm{w} / 0$ carbon (corresponding to $\mathrm{PuC}_{2}$ ) which melts at about $2200 \mathrm{C}$.

Shonfeld, Cramer, Miner, Ellinger, and Coffinberry(2) report that there is a eutectic between PuC and plutonium at an unknown location and that PuC forms by a peritectic reaction at about $1200 \mathrm{C}$. In view of the fact that plutonium is a material with a very low melting point, the formation of $\mathrm{PuC}$ by a peritectic reaction seems reasonable. The data obtained by Drummond, et al., may represent a material having some contamination by uranium.

\section{Crystallography}

PuC: fcc ( $\mathrm{NaCl}, \mathrm{Bl}$ type), a $=4.97 \mathrm{~A}$, four molecules per unit cell; density = $13.6 \mathrm{~g}$ per $\mathrm{cm}^{3}$.

$\mathrm{Pu}_{2} \mathrm{C}_{3}:$ bcc (space group $\overline{\mathrm{4}} \overline{4} 3 \mathrm{~d}$ ), $a=8.129 \mathrm{~A}$, eight molecules per unit cell; density $=12.7 \mathrm{~g}$ per $\mathrm{cm}^{3}$. 


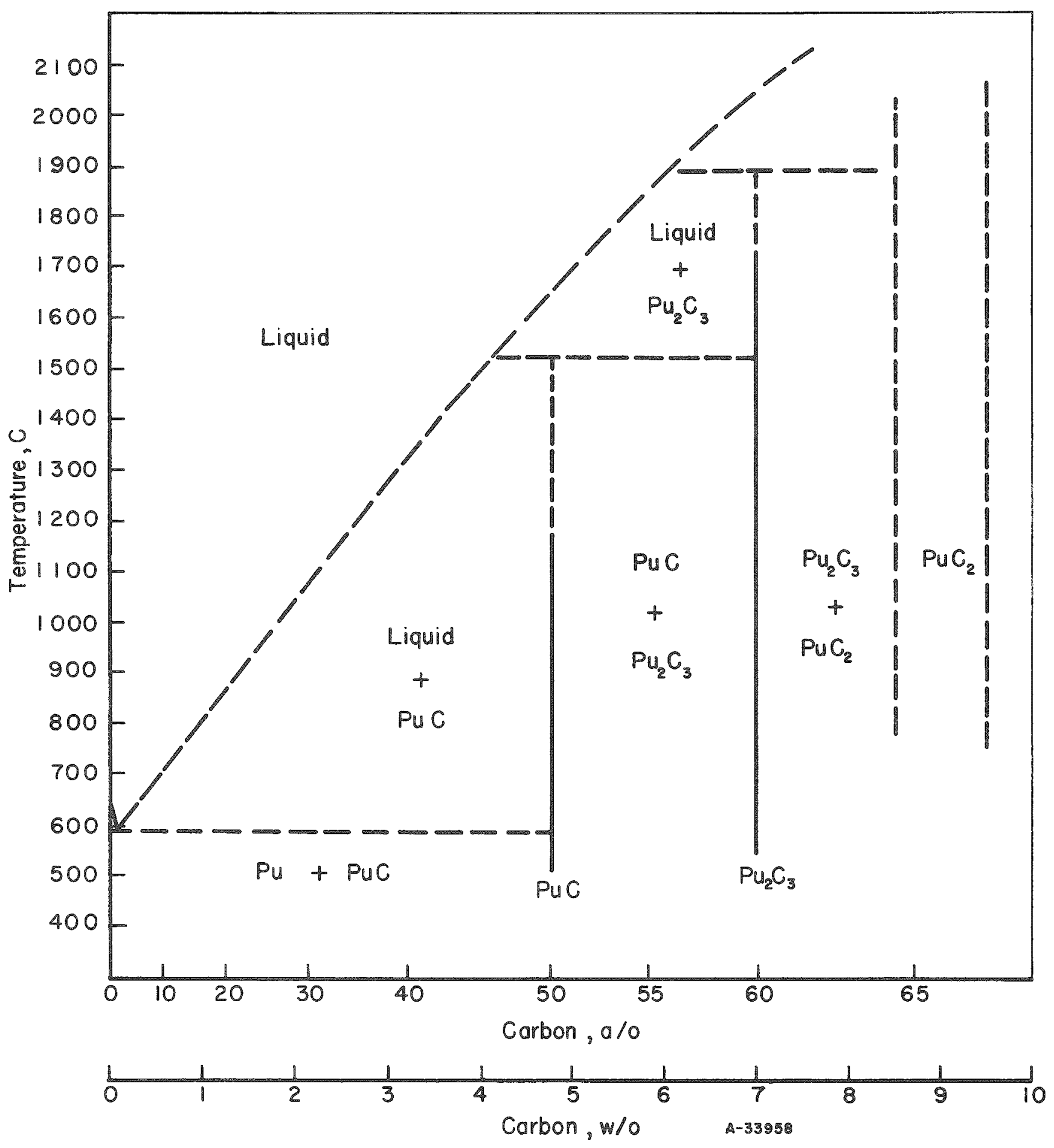

FIGURE 25. PLUTONIUM-CARBON CONSTITUTIONAL DIAGRAM 
$\underline{\text { References }}$

(1) Drummond, J. L., McDonald, B. J., Ockenden, H. M., Welch, G. A., "The Preparation and Properties of Some Plutonium Compounds, VII, Plutonium Carbide", J. Chem. Soc. (London), p 4785 (1957).

(2) Schonfeld, F. W., Cramer, E. M., Miner, W. N., Ellinger, F. H., and Coffinberry, A. S., "Plutonium Constitutional Diagrams", Progress in Nuclear Energy, Series V, Metallurgy and Fuels, Vol II, Pergamon Press, New York (1959), pp 579-99.

\section{PLUTONIUM-CARBON TERNARY SYSTEMS}

\section{Nitrogen}

\section{Constitution}

Coffinberry and Ellinger(1) state that "PuC, PuN, and PuO have appreciable mutual solid solubility, as well as homogeneity ranges for each binary phase, and differences in content of carbon, nitrogen, and oxygen are difficult to control or to determine". Since PuC and PuN are isomorphous and their unit-cell sizes differ by only 1 per cent, it would be very surprising if PuC and PuN were not completely soluble in one another.

\section{Crystallography}

PuN: fcc (NaCl, B1 type), a $=4.905 \mathrm{~A}$, four molecules per unit cell; density = $14.2 \mathrm{~g}$ per $\mathrm{cm}^{3}$.

Reference

(1) Coffinberry, A. S., and Ellinger, F. H., "The Intermetallic Compounds of Plutonium", No. 826, Proceedings of the [First United Nations] International Conference on the Peaceful Uses of Atomic Energy, New York (1956), Vol 9, A/Conf. 8/P/826, pp 138-46.

\section{Oxygen}

\section{Constitution}

In 1955, Coffinberry and Ellinger (1) reported that PuO and PuC had appreciable mutual solid solubility and that PuO was face-centered cubic with a lattice parameter of $4.96 \mathrm{~A}$. Since this is intermediate to that of $\mathrm{PuC}(\mathrm{a}=4.97 \mathrm{~A})$ and $\mathrm{PuN}(\mathrm{a}=4.90 \mathrm{~A})$, which are probably mutually soluble, it seems likely that the PuO observed was really $\mathrm{Pu}(\mathrm{C}, \mathrm{N})$. 
In 1959, Schonfeld, Cramer, Miner, Ellinger, and Coffinberry( 2$)$ stated that "PuO has not been observed except as formed under special conditions." They also observed that "The solubility of oxygen in molten plutonium up to $1000 \mathrm{C}$ does not exceed 30 ppm by weight." Since plutonium represents an oxidation state intermediate to that of PuC and plutonium oxide, it may be assumed that the solubility of oxygen in the plutonium carbides is similar to or less than that of oxygen in plutonium.

\section{References}

(1) Coffinberry, A. S., and Ellinger, F. H., "The Intermetallic Compounds of Plutonium", Proceedings of the [First United Nations] International Conference on the Peaceful Uses of Atomic Energy, New York (1956), Vo1 9, A/Conf. 8/P/826, pp 138-46.

(2) Schonfeld, F. W., Cramer, E. M., Miner, W. N., Ellinger, F. H., and Coffinberry, A. S., "Plutonium Constitutional Diagrams", Progress in Nuclear Energy, Series V, Metallurgy and Fuels, Vol II, Pergamon Press, New York (1959), pp 579-599.

\section{Uranium}

Plutonium-carbon-uranium compositions are discussed in the section on uranium-carbon ternary systems.

\section{QUATERNARY SYSTEMS}

Uranium-Thorium-Carbon-Zirconium

\section{Constitution}

The pseudoternary system involving the monocarbides of thorium, uranium, and zirconium has been investigated by Ivanov and Badayeva(1). This investigation disclosed the existence of solubility in the pseudoternary system in all alloys containing more than 70 mole per cent UC and in all alloys containing less than 6 mole per cent $\mathrm{ZrC}$. The alloys were examined both in the as-cast condition and as annealed at $2000 \mathrm{C}$ and furnace cooled. No changes in constitution were observed as a result of these changes in heat treatment.

A ThC-UC-ZrC section is shown in Figure 26. 
(1) Ivanov, O. S., and Badayeva, T. A., "Phase Diagrams of Certain Uranium and Thorium Systems", Proceedings of the Second United Nations International Conference on the Peaceful Uses of Atomic Energy, Geneva (1958), Vol 6, A/Conf. 15/P/2043, p 139.

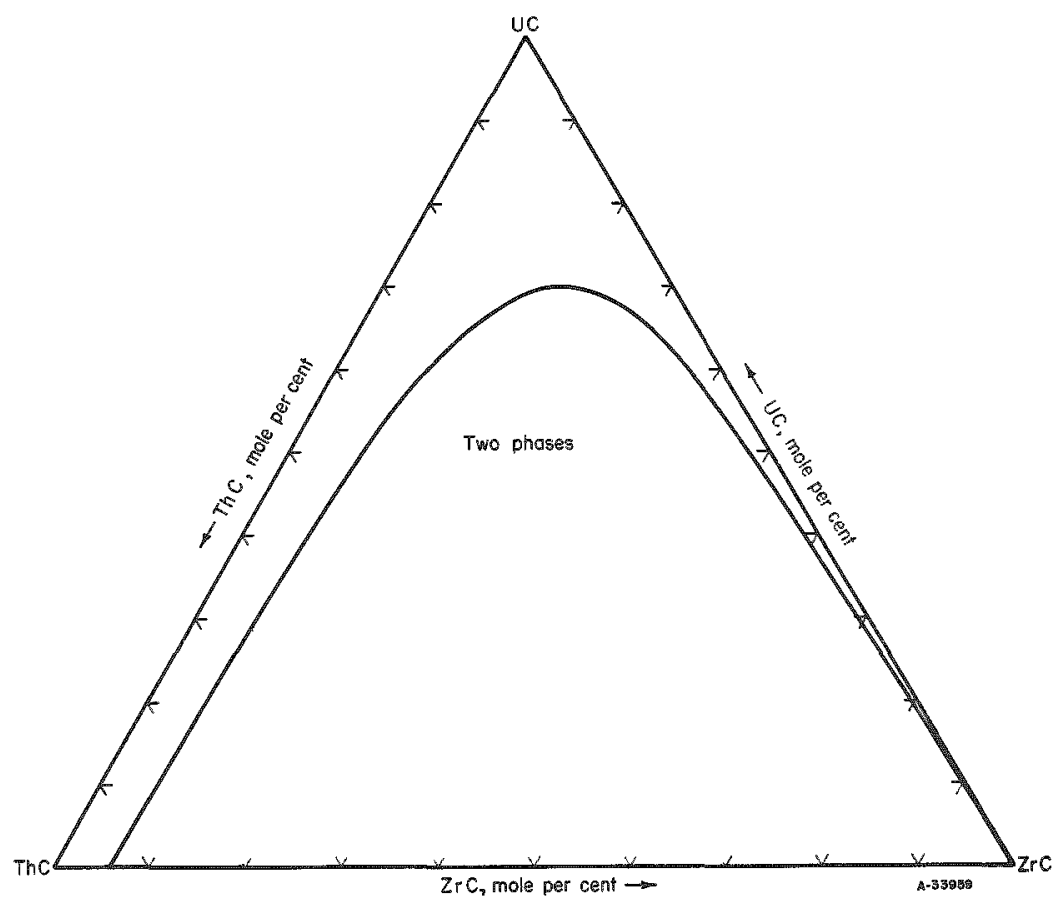

FIGURE 26. ThC-UC-ZrC SECTION AT 2000 TO $2400 \mathrm{C}$ 
COMPATIRIIITY AND CORPOSION BEHAVIOR OF NUCLEAR CARBIDES

W. M. Phillips and J. J. Ward

Introduction

This section consists of a brief summary of the presently available data on compatibility and corrosion behavior of uranium carbides. Essentially, no such data are available on thorium and plutonium carbides. The data reviewed include those available on compatibility with metallic cladding or matrix materials, and with liquid and gaseous coolants and chemicals. Also included are thermodynamic data calculated for the reaction of uranium, thorium, and plutonium carbides with various selected coolants. Similar data are included for the reaction of UC with the refractory metals molybdenum, niobium, tantalum, and tungsten. Additional information on the compatibility of these carbides with metallic materials can be obtained in the section on constitution.

At best, compatibility is a difficult thing to define, and usually the observed results are highly dependent on the experimental conditions and the quality of materials used in the test. The data presented are sparse and based on limited experimentation, and offer little opportunity for evaluation. The situation is rather similar for the few data available for the corrosion of carbides in various media. Here also the results will be greatly affected by fabrication history and the quality of materials, since variations in chemical composition and type and amount of porosity and cracking will affect both the chemical reactivity and the rate of attack.

The thermodynamic data presented are believed to be the best available. However, the relatively low free energy of formation of these carbides means that appreciable error may be present in calculations of the free energy of the various chemical reactions considered.

Thermodynamics of Reactions With Coolants and With Claddings

The thermodynamics of reaction of gaseous coolants such as nitrogen, oxygen, CO, $\mathrm{CO}_{2}$, and $\mathrm{H}_{2} \mathrm{O}$ are presented in Table 5. Liquid coolants such as $\mathrm{NaK}$, sodium and terphenyl were also considered. No reaction between these liquids and UC is predicted; but the data are not completely satisfactory, since the solubility of the carbides in the liquids is not known. Thus, the calculated data are not included.

Similarly, thermodynamic data on the reaction of carbides with metals cannot be considered completely satisfactory unless data on the solubility of the carbides in the metals are available. Although the needed solubility data are not available, data are presented in Table 6 for the reaction potentials of UC with molybdenum, niobium, tantalum, and tungsten, neglecting the possibility of solubility of the UC in these metals. The results indicate that molybdenum and tungsten should not react with UC while tantaIum and niobium should. One obvious discrepancy arises when these predictions are compared with the data shown below and in the constitution section. It is reported that molybdenum reacts with UC to form $\mathrm{Mo}_{2} \mathrm{C}$. 
TABLE 5. STANDARD FREE-ENERGY CHANGE FOR CARBIDE REACTIONS WITH COOLANTS

\begin{tabular}{|c|c|c|c|c|c|}
\hline \multirow[b]{2}{*}{ Reaction } & \multicolumn{5}{|c|}{ Standard Free-Energy Change, $\Delta G_{T}^{\circ}$, cal } \\
\hline & $600 \mathrm{~K}$ & $800 \mathrm{~K}$ & $1000 \mathrm{~K}$ & $1200 \mathrm{~K}$ & $1400 \mathrm{~K}$ \\
\hline $\mathrm{UC}(\mathrm{s})+3 \mathrm{H}_{2} \mathrm{O}(\mathrm{g}) \rightleftharpoons \mathrm{UO}_{2}(\mathrm{c})+3 \mathrm{H}_{2}(\mathrm{~g})+\mathrm{CO}(\mathrm{g})$ & $-100,320$ & $-105,010$ & -- & -- & $\infty$ \\
\hline $\mathrm{UC}_{2}(\mathrm{c})+4 \mathrm{H}_{2} \mathrm{O}(\mathrm{g})=\mathrm{UO}_{2}(\mathrm{c})+4 \mathrm{H}_{2}(\mathrm{~g})+2 \mathrm{CO}(\mathrm{g})$ & $-68,020$ & $-79,300$ & -- & -- & $-\infty$ \\
\hline $\mathrm{ThC}_{2}(\mathrm{c})+4 \mathrm{H}_{2} \mathrm{O}(\mathrm{g})=\mathrm{ThO}_{2}(\mathrm{c})+4 \mathrm{H}_{2}(\mathrm{~g})+2 \mathrm{CO}(\mathrm{g})$ & $-95,780$ & $-105,680$ & -- & $-\infty$ & $-\infty$ \\
\hline $\mathrm{PuC}(\mathrm{c})+3 \mathrm{H}_{2} \mathrm{O}(\mathrm{g})=\mathrm{PuO}_{2}(\mathrm{c})+3 \mathrm{H}_{2}(\mathrm{~g})+\mathrm{CO}(\mathrm{g})$ & $-82,610$ & $-86,860$ & -- & $-\infty$ & -- \\
\hline $\mathrm{UC}(\mathrm{c})+3 / 2 \mathrm{O}_{2}(\mathrm{~g}) \rightleftharpoons \mathrm{UO}_{2}(\mathrm{c})+\mathrm{CO}(\mathrm{g})$ & $-253,770$ & $-250,930$ & -- & -- & -- \\
\hline $\mathrm{UC}_{2}(\mathrm{c})+2 \mathrm{O}_{2}(\mathrm{~g})=\mathrm{UO}_{2}(\mathrm{c})+2 \mathrm{CO}(\mathrm{g})$ & $-272,600$ & $-273,860$ & $-\infty$ & -- & $-\infty$ \\
\hline $\mathrm{ThC}_{2}(\mathrm{c})+2 \mathrm{O}_{2}(\mathrm{~g})=\mathrm{ThO}_{2}(\mathrm{c})+2 \mathrm{CO}(\mathrm{g})$ & $-300,380$ & $-300,240$ & -- & $-\infty$ & - \\
\hline $\mathrm{PuC}(\mathrm{c})+3 / 2 \mathrm{O}_{2}(\mathrm{~g}) \rightleftharpoons \mathrm{PuO}_{2}(\mathrm{c})+\mathrm{CO}(\mathrm{g})$ & $-236,060$ & $-232,780$ & -- & $-\infty$ & -- \\
\hline $\mathrm{UC}(\mathrm{c})+3 \mathrm{CO}_{2}(\mathrm{~g})=\mathrm{UO}_{2}(\mathrm{c})+4 \mathrm{CO}(\mathrm{g})$ & $-88,650$ & $-98,350$ & -- & -- & $-\infty$ \\
\hline $\mathrm{UC}_{2}(\mathrm{c})+4 \mathrm{CO}_{2}(\mathrm{~g}) \rightleftharpoons \mathrm{UO}_{2}(\mathrm{c})+6 \mathrm{CO}(\mathrm{g})$ & $-52,460$ & $-70,420$ & -- & -- & $-\infty$ \\
\hline $\mathrm{ThC}_{2}(\mathrm{c})+4 \mathrm{CO}_{2}(\mathrm{~g})=\mathrm{ThO}_{2}(\mathrm{c})+6 \mathrm{CO}(\mathrm{g})$ & $-80,220$ & $-96,800$ & $-\infty$ & -- & -- \\
\hline $\mathrm{PuC}(\mathrm{c})+3 \mathrm{CO}_{2}(\mathrm{~g})=\mathrm{PuO}_{2}(\mathrm{c})+4 \mathrm{CO}(\mathrm{g})$ & $-79,940$ & $-80,200$ & -- & $-\infty$ & $-\infty$ \\
\hline $\mathrm{UC}(\mathrm{c})+2 \mathrm{CO}(\mathrm{g})=\mathrm{UO}_{2}(\mathrm{c})+3 \mathrm{C}(\mathrm{graphite})$ & $-135,690$ & $-119,890$ & -- & -- & $-72,980$ \\
\hline $\mathrm{UC}_{2}(\mathrm{c})+2 \mathrm{CO}(\mathrm{g}) \rightleftharpoons \mathrm{UO}_{2}(\mathrm{c})+4 \mathrm{C}($ graphite $)$ & $-115,180$ & $-99,140$ & -- & -- & $-51,480$ \\
\hline $\mathrm{ThC}_{2}(\mathrm{c})+2 \mathrm{CO}(\mathrm{g})=-\mathrm{ThO}_{2}(\mathrm{c})+4 \mathrm{C}(\mathrm{g}$ raphite $)$ & $-142,940$ & $-125,520$ & -- & -- & $-74,320$ \\
\hline $\mathrm{PuC}(\mathrm{c})+2 \mathrm{CO}(\mathrm{g}) \rightleftharpoons \mathrm{PuO}_{2}(\mathrm{c})+3 \mathrm{C}$ (graphite) & $-117,980$ & $-101,740$ & -- & -- & $-53,180$ \\
\hline$U C(c)+1 / 2 N_{2}(g)=U N(c)+C($ graphite $)$ & $-35,910$ & $-29,790$ & $-28,990$ & $-25,530$ & $-22,100$ \\
\hline $\mathrm{UC}_{2}(\mathrm{c})+1 / 2 \mathrm{~N}_{2}(\mathrm{~g})=\mathrm{UN}(\mathrm{c})+2 \mathrm{C}(\mathrm{graphite})$ & $-15,400$ & $-11,700$ & $-8,000$ & $-4,300$ & -600 \\
\hline $\operatorname{ThC}_{2}(c)+2 / 3 N_{2}(g)=1 / 3 \operatorname{Th}_{3} N_{4}(c)+2 C$ (graphite) & $-42,000$ & $-36,550$ & $-31,090$ & $-25,640$ & $-20,190$ \\
\hline $\mathrm{PuC}(\mathrm{c})+1 / 2 \mathrm{~N}_{2}(\mathrm{~g})=\mathrm{PuN}(\mathrm{c})+\mathrm{C}(\mathrm{graphite})$ & $-61,000$ & $-58,000$ & $-55,000$ & $-52,000$ & $-49,000$ \\
\hline
\end{tabular}




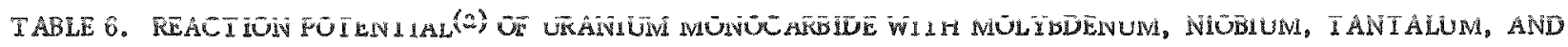
TUNGSTEN METALS AS A FUNCTION OF TEMPERATURE

\begin{tabular}{|c|c|c|c|c|c|c|c|c|c|}
\hline & \multirow[b]{2}{*}{$900 \mathrm{~K}$} & \multirow[b]{2}{*}{$1000 \mathrm{~K}$} & \multicolumn{5}{|c|}{ Standard Free Energy of Reaction, $\Delta G_{T}^{\circ}$, cal } & \multirow[b]{2}{*}{$2200 \mathrm{~K}$} & \multirow[b]{2}{*}{$2400 \mathrm{~K}$} \\
\hline & & & $1200 \mathrm{~K}$ & $1400 \mathrm{~K}$ & $1600 \mathrm{~K}$ & $1800 \mathbb{K}$ & $2000 \mathrm{~K}$ & & \\
\hline $\mathrm{UC}(\mathrm{c})+2 \mathrm{Mo}(\mathrm{c}) \rightarrow \mathrm{U}+\mathrm{Mo}_{2} \mathrm{G}(\mathrm{c})$ & $+11,700$ & $+11,310$ & $+10,470$ & $+9,600$ & $\$ 8,500$ & $+7,900$ & $+7,300$ & $+6,700$ & $+6,100$ \\
\hline$U C(c)+W(c)=U+W C(c)$ & 49,660 & +9.310 & $+8,550$ & $+7,760$ & $+6,740$ & $\div 6,220$ & $\div 5,700$ & $+5,180$ & $+4,660$ \\
\hline $\mathrm{UC}(\mathrm{c})+\mathrm{Ta}(\mathrm{c}) \rightleftharpoons \mathrm{U}+\mathrm{TaC}(\mathrm{c})$ & -19.060 & $-19,330$ & $-19,940$ & $-20,580$ & $-21,140$ & $-21,810$ & $-22,180$ & $-22,550$ & $-22,920$ \\
\hline$U C(c)+N b(c) \Rightarrow U+N b C(c)$ & $-14,220$ & $-14,490$ & $-15,090$ & $-15,720$ & $-16,580$ & $-16,940$ & $-17,300$ & $-17,660$ & $-18,020$ \\
\hline
\end{tabular}

(a) These dara indicate that UC is chemically stable with respect to tungsten and molybdenum over the range of 900 to $2400 \mathrm{~K}$. The stability tends to decrease with increasing temperature. The data indicate that tantalum and niobium tend to react chemically with UC and that the tendency increases with increasing temperature. These data give no information on behavior patterns dependent upon solubilities of carbides in metals.

\section{Compatibility With Metals}

\section{Aluminum}

Work at Oak Ridge(1) has shown the reaction between aluminum and uranium carbide at $620 \mathrm{C}$ to vary as a function of carbon content, as shown in Table 7.

TABLE 7. REACTION BETWEEN ALUMINUM AND UC AT $620 \mathrm{C}^{(1)}$

\begin{tabular}{|c|c|c|c|c|c|c|c|}
\hline \multirow{2}{*}{$\begin{array}{c}\text { Time at } \\
620 \mathrm{C}, \mathrm{hr} \\
\end{array}$} & \multicolumn{7}{|c|}{ Reaction(a) Occurring With Alloy Shown } \\
\hline & $\mathrm{U}-9.2 \mathrm{~W} / \mathrm{OC}$ & $\mathrm{U}-8.24 \mathrm{w} / \mathrm{OC}$ & $\mathrm{U}-7.98 \mathrm{w} / \mathrm{OC}$ & $\mathrm{U}-6.96 \mathrm{w} / \mathrm{OC}$ & $\mathrm{U}-5.75 \mathrm{w} / \mathrm{0} \mathrm{C}$ & $\mathrm{U}-4.86 \mathrm{w} / \mathrm{OC}$ & $\mathrm{U}-4.46 \mathrm{~W} / 0 \mathrm{C}$ \\
\hline 4 & NR & NR & NR & NR & $\mathrm{NR}$ & NR & $\Delta V=1.2 \%$ \\
\hline 10 & NR & NR & NR & NR & $\Delta V=71 \%$ & $\Delta V=88 \%$ & $C D$ \\
\hline 16 & NR & NR & NR & $\mathrm{NR}$ & & & \\
\hline 24 & NR & NR & NR & $\begin{array}{l}5 \% \mathrm{UAl}_{4} \\
\Delta \mathrm{V}=4.6 \%\end{array}$ & & & \\
\hline 48 & NR & $5 \% \mathrm{UAl}_{3}$ & $\begin{array}{c}1 \% \mathrm{UA1}_{3} \\
1 \% \mathrm{UAl}_{4} \\
\mathrm{~V} \approx 0.6 \%\end{array}$ & & & & \\
\hline 74 & $\mathbb{N R}$ & $5 \% \mathrm{UAI}_{3}$ & & & & & \\
\hline 96 & $49 \mathrm{UAI}_{4}$ & & & & & & \\
\hline
\end{tabular}

(a) Code:

NR $:$ No reaction

$\Delta V:$ Change in volume of specimen

$C D=$ Complete disintegration.

Beryllium

A. Boettcher, et al. (2) found beryllium to bond to UC at $650 \mathrm{C}$ in $12 \mathrm{hr}$ under a pressure of $15 \mathrm{~kg}$ per $\mathrm{mm}^{2}$. 
P. Murray, et al., (3) found reaction between $\mathrm{U}_{2} \mathrm{C}_{3}$ or $\mathrm{UC}_{2}$ and beryllium between 600 and $1000 \mathrm{C}$.

\section{Bismuth}

No reaction between molten bismuth and UC was observed during heating to $950 \mathrm{C}$ and subsequent cooling. (4) At $1100 \mathrm{C}$, bismuth does not react with either $\mathrm{UC}_{2}$ or $\mathrm{U}_{2} \mathrm{C}_{3}(4)$, both of which are considered to be more reactive than the monocarbide.

Lead

Molten lead will not wet UC by dipping. (2)

Molybdenum

Reaction between UC and molybdenum was observed metallographically after sintering at 1200 C. (5)

Nickel

Nickel has been deposited on UC by both vacuum evaporation and electrolytic deposition. Annealing of these specimens for $10 \mathrm{~min}$ at $1000 \mathrm{C}$ produced two layers between the UC and the nickel, one $\mathrm{U}_{6} \mathrm{Ni}$, the other of unknown composition. (2)

\section{Nichrome V}

A mixture of 30 volume per cent of UC in Nichrome $V$ showed metallographic evidence of reaction and melting after sintering at $1200 \mathrm{C}$. (5)

Niobium

Metallographic evidence of reaction between niobium and UC was observed after sintering at $1200 \mathrm{C}$. (5)

Niobium-Titanium

A niobium-40 a/o titanium alloy in contact with UC was found to react, producing a molten phase at 1200 C. (5)

\section{Silicon}

Siliconization was found to take place at $1000 \mathrm{C}$, producing USi3 on the surface of UC in contact with silicon metal. (2) 


\section{Sodium and NaK}

Nichols(6) reports satisfactory compatibility of UC with $\mathrm{NaK}$ at $800 \mathrm{C}$ after 1 month's exposure. Price, et al., (7) ran tests involving cast uranium-5 w/o carbon specimens held in molybdenum or Type 304 stainless steel baskets immersed in NaKfilled stainless steel capsules. After 2 to 6 weeks at $1300 \mathrm{~F}$ and 12 weeks at $1100 \mathrm{~F}$, the carbide specimens were intact except for minor weight losses.

Steel

Mild steel was found to react with uranium monocarbide at $1000 \mathrm{C}$ in $24 \mathrm{hr}$. (8)

\section{Stainless Steel}

Stainless steel could not be bonded to uranium monocarbide at $650 \mathrm{C}$ in $12 \mathrm{hr}$ under a pressure of $15 \mathrm{~kg}$ per mm2. (2) Uranium monocarbide was found to react with stainless steel in $24 \mathrm{hr}$ at $1000 \mathrm{C}$. (8) Type 304 stainless steel, used to contain UC specimens in a NaK environment, was embrittled by an exposure of 12 weeks at $1100 \mathrm{~F}$. (7) Nichols $(6)$ reports that UC and stainless are compatible at $1000 \mathrm{C}$ and that $0.004 \mathrm{in}$. penetration occurred during 6 days at $1100 \mathrm{C}$.

Tantalum

Tantalum will displace uranium from uranium monocarbide. The reaction is slow at $1000 \mathrm{C}$ but becomes rapid near the melting point of uranium monocarbide. (9)

Tin

Molten tin will not wet uranium carbide by dipping. (2)

\section{Titanium}

Nichols(6) reports that reaction occurs between UC and titanium at $1100 \mathrm{C}$, the penetration amounting to 0.005 in. in 6 days at temperature. Very marked reaction was observed at $1200 \mathrm{C}$.

Zinc

Molten zinc will wet uranium carbide by dipping. (2)

$\underline{\text { Zircaloy }-2}$

Zircaloy-2 was found to react with uranium carbide in $1 \mathrm{hr}$ at $1200 \mathrm{C}(10)$ but not at $800 \mathrm{C}(11)$. 


\section{Zirconium}

Zirconium was bonded to uranium carbide at $650 \mathrm{C}$ in $12 \mathrm{hr}$ under a pressure of $15 \mathrm{~kg}$ per $\mathrm{mm}^{2}$. (2) Considerable reaction was observed between zirconium and uranium carbide at $1000 \mathrm{C}$ and $1200 \mathrm{C}$ in $24 \mathrm{hr} .(5,8)$

Air, Oxygen, and Nitrogen

Uranium monocarbide is attacked very slowly by moist air at room temperature, but it can be handled in bulk form, if exposure to moisture is minimized as by storage in a desiccator. It is reported that $\mathrm{UC}_{2}$ is attacked more rapidly in air than is $\mathrm{UC}$. Thus, the presence of $\mathrm{UC}_{2}$ as a second phase in UC may accentuate this difficulty. (12)

Uranium dicarbide reacts with both oxygen and nitrogen at a rate which is parabolic as a function of temperature. At $300 \mathrm{C}$, the reaction with oxygen becomes anisothermal. A summary of these data appears in Table 8.

TABLE 8. CORROSION OE URANIUM DICARBIDE IN WATER VAPOR, NITROGEN, AND OXYGEN

\begin{tabular}{|c|c|c|c|c|}
\hline \multirow[b]{2}{*}{$\begin{array}{c}\text { Test } \\
\text { Medium }\end{array}$} & \multirow[b]{2}{*}{$\begin{array}{c}\text { Temperature, } \\
C\end{array}$} & \multicolumn{2}{|c|}{ Corrosion Rate } & \multirow[b]{2}{*}{ Reference } \\
\hline & & $\begin{array}{c}\text { Linear, } \\
\mathrm{mg} /\left(\mathrm{cm}^{2}\right)(\mathrm{sec})\end{array}$ & $\begin{array}{c}\text { Parabolic } \\
\left(\mathrm{mg} / \mathrm{cm}^{2}\right)^{2} / \mathrm{sec}\end{array}$ & \\
\hline \multirow[t]{3}{*}{$29 \mathrm{~mm} \mathrm{H}_{2} \mathrm{O}$} & 50 & 0.04 & -- & 13 and 14 \\
\hline & 150 & 0.66 & - & 13 and 14 \\
\hline & 200 & 3.2 & -- & 13 and 14 \\
\hline \multirow{3}{*}{$\mathrm{H}_{2} \mathrm{O}$ vapor } & 250 & $=-$ & 6520 & 13 \\
\hline & 300 & -- & 9210 & 13 \\
\hline & 300 & -- & 6840 & 13 \\
\hline \multirow[t]{3}{*}{ Nitrogen } & 400 & -- & 16 & 14 \\
\hline & 600 & -. & 860 & 14 \\
\hline & 700 & -- & 3300 & 14 \\
\hline \multirow[t]{4}{*}{ Oxygen } & 150 & $-\infty$ & 6.1 & 14 \\
\hline & 200 & -- & 75 & 14 \\
\hline & 250 & $=-$ & 900 & 14 \\
\hline & 300 & $\ldots$ & Anisothermal & 14 \\
\hline
\end{tabular}

\section{Compatibility With Liquids and Gases}

\section{Water}

It has been generally noted that UC has very poor compatibility with water at any temperature. Nichols $(6)$ reports that rapid decomposition results from exposure to water at temperatures above $80 \mathrm{C}$. The gaseous reaction products evolved during hydrolysis of UC at 83 to $400 \mathrm{C}$ were analyzed by Litz(15). The liberated gas was composed of hydrogen and methane with a hydrogen concentration varying from 12 per cent at $83 \mathrm{C}$ to 100 per cent at $400 \mathrm{C}$. At all temperatures, the solid reaction product was 
UO2. Appuecialuli ratos of rcaction bctwocn water and uranium carbide have heen noted at temperatures as low as $40 \mathrm{C}$. (16) Several investigators have determined the corrosion rate of the dicarbide in water vapor as summarized in Table 8 . The results indicate that the rate is linear at $200 \mathrm{C}$ and below, but parabolic above this temperature.

Alkalies and Acids

Concentrated acids will react slowly with UC at room temperature, the reaction rate increasing with temperature. (17) Allalies will readily decompose UC2. (18)

\section{Organics}

Some organic materials react with the carbides of uranium. When UC was exposed in glycerin at $100 \mathrm{C}$ a weight-1oss rate of $50 \mathrm{mg} /\left(\mathrm{cm}^{2}\right)(\mathrm{hr})$ was measured. (2) Terphenyl (Santowax R) corroded UC at the rate of approximately $5 \mathrm{mg} /\left(\mathrm{cm}^{2}\right)(\mathrm{hr})$ at $350 \mathrm{C}$, probably as a result of traces of contained moisture. A weight $10 \mathrm{ss}$ of $0.4 \mathrm{mg} /\left(\mathrm{cm}^{2}\right)(\mathrm{hr})$ occurred during exposure of UC to ethylene glycol at 150 C. (19)

\section{Halogens}

Uranium dicarbide will react with the halogens, usually to form compounds of the $\mathrm{UX}_{4}$ type. The results are summarized in Table 9. (17)

TABLE 9. REACTION OF UC 2 WITH THE HALOGENS(17)

\begin{tabular}{|c|c|c|c|}
\hline Reactant & $\begin{array}{c}\text { Temperature, } \\
\text { C }\end{array}$ & Product & Comments \\
\hline \multirow[t]{2}{*}{ Chlorine } & 350 & Volatile chloride & $=$ \\
\hline & 600 & $\mathrm{UCl}_{4}$ & $-\infty$ \\
\hline \multirow[t]{2}{*}{ Fluorine } & 30 & $\ldots$ & No reaction \\
\hline & 30 & -- & Explosive reaction \\
\hline \multirow[t]{2}{*}{ Bromine } & 390 & -- & Ignites in bromine vapor \\
\hline & $800-900$ & $\mathrm{UBr}_{4}$ & $\ldots$ \\
\hline Iodine & 500 & $\mathrm{UI}_{4}$ & -- \\
\hline
\end{tabular}

$\mathrm{CO}_{2}$ pressure. (6)

Uranium monocarbide oxidizes at $500 \mathrm{C}$ in a $\mathrm{CO}_{2}$ atmosphere at an 8 -atm gas

$\underline{\mathrm{H}_{2} \mathrm{~S}}$

Uranium monocarbide ignited in $\mathrm{H}_{2} \mathrm{~S}$ at $600 \mathrm{C}$ producing a sulfide. (17) 
$\underline{\mathrm{NH}_{3}}$

Uranium dicarbide was partially decomposed by $\mathrm{NH}_{3}$ at a red heat. (17)

Hydrogen

UC is compatible with hydrogen, if no second phases are present. (6)

Solvents

Acetone, alcohol, benezene, carbon tetrachloride, kerosene, xylene, and Zyglo solutions did not react with UC during a $5-\mathrm{hr}$ exposure at room temperature.

\section{References}

(1) Thurber, W. C., and Beaver, R. J., "Dispersions of Uranium Carbides in Aluminum Plate-Type Research Reactor Fuel Elements", ORNL-2618 (November, 1959).

(2) Boettcher, A., and Schneider, G., "Some Properties of Uranium Monocarbide", Proceedings of the Second United Nations International Conference on the Peaceful Uses of Atomic Energy, Geneva (1958), Vol 6, A/Conf. 15/P/964, pp 561-63.

(3) Murray, P., and Williams, J., "Ceramic and Cermet Fuels", Proceedings of the Second United Nations International Conference on the Peaceful Uses of Atomic Energy, Geneva (1958), Vol 6, A/Conf. 15/P/318, pp 538-50.

(4) "Technological Research, Section II, Report for Month Ending January 15, 1943", Chicago University Metallurgical Laboratory, CT-423.

(5) "Quarterly Technical Progress Report for Period Ending June 30, 1958", SCNC279 (September, 1958). Secret.

(6) Nichols, R. W., "Ceramic Fuels - Properties and Technology", Nuclear Eng., (August, 1958).

(7) Price, R. B., Stahl, D., Stang, J. H., and Simons, E. M., "Irradiation-Capsule Study of Uranium Monocarbide", BMI-1425 (March 2, 1960).

(8) Dayton, R. W., and Tipton, C. R., Jr., "Progress Relating to Civilian Applications During September, 1959", BMI-1381 (October 1, 1959), p 58.

(9) Bowman, M. G., "Bonding Uranium Carbide to Tantalum", AECU-4303 (May, 1959).

(10) "Development and Properties of Uranium Monocarbide Cermets", Armour Research Foundation, AECD-4289 (December 10, 1959). 


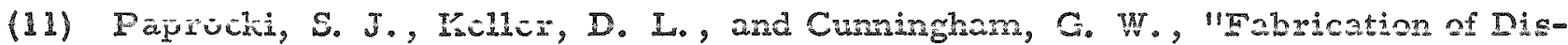
persed. Uranium Fuel Elements Using Powder Metallurgy Techniques", BMI1184 (May 6, 1957).

(12) Barnes, E., Munro, W., Thackery, R. W., Williams, J., and Murray, P., "The Preparation, Fabrication, and Properties of Uranium Carbide and UraniumUranium Carbide Cermets", Metallurgy and Fuels, Edited by H. M. Finniston and J.P. Howe, Pergamon Pxess (1956), pp 435-47.

(13) Dayton, R. W., and Tipton, C. R., Jr., "Progress Relating to Civilian Applications During November, 1957", BMI-1238 (December 1, 1957), p 48.

(14) Albrecht, W. M., and Koehl, B. G., "Reactivity of Uranium Compounds in Several Gaseous Media", Proceedings of the Second United Nations International Conference on the Peaceful Uses of Atomic Energy, Geneva (1958), Vol 6, A/Conf. 15/P/710, pp 116-21.

(15) Litz, L. M., "Uranium Carbides - Their Properties, Structure, and Hydrolysis", Ph. D. Dissertation, The Ohio State University, AEC Document NP-1453 (1948).

(16) Phillips, W. M., BMI, Unpublished Information.

(17) Baker, J. E., "Report on the Carbides of Uranium: UC, UC2, and $\mathrm{U}_{2} \mathrm{C}_{3}$ ", NEPA273 (August 7, 1947).

(18) Baker, J. E., "Uranium Carbide-Technical Report", NEPA-138 (December 31, 1946).

(19) Dayton, R. W., and Tipton, C. R., Jr., "Progress Relating to Civilian Applications During October, 1959", BMI-1391(Rev.), (November 1, 1959), p 61. 


\title{
PREPARATION AND FABRICATION OF NUCLIEAR CARBIDES
}

\section{THERMODYNAMICS}

\author{
J. I. Ward and $G$. W. Cunningham
}

Introduction

The thermodynamic data presented here have been used primarily in studies of the preparation of carbides. Although the basic data were obtained from the literature, as indicated, calculations nade by the authors on some of the more interesting reactions also have been included. In the latter instances, it was necessary to extrapolate $10 \mathrm{w}-$ temperature data for use at high temperatures, and, consequently, the calculated data presented in various reactions are estimated values only.

Teactions considured for preparation of the carbides include those involving gaseous reactants, condensed-phase reactants (gas-liquid and gas-solid), and solid-solid reactans. Basic data available for uranium, thoriun, and plutonium carbides which apply to all these teactims are listed in Table 10. These data were selected for use because they appea to be the most reliable data available. A more detailed compilation of the thermodynamic data available in the literature has been published by Strasser(1).

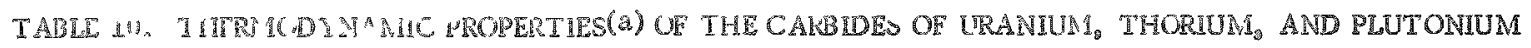

\begin{tabular}{|c|c|c|c|c|}
\hline & $\mathrm{Uc}(\mathrm{b})$ & $\mathrm{UC}_{2}(\mathrm{~b})$ & $\mathrm{ThC}_{2}$ & PuC \\
\hline 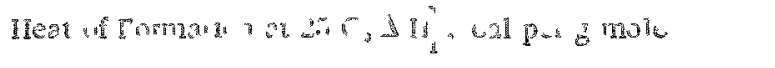 & $-20,000$ & $-42,000$ & $-44,800$ & $-25,000$ \\
\hline 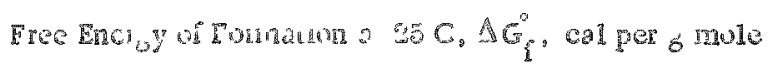 & $-18,900$ & $-41_{0}, 1 \% 0$ & $-44,030$ & $-24,400$ \\
\hline 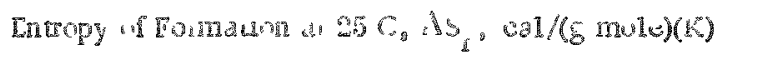 & -3.70 & -3.0 & -2.6 & -2.0 \\
\hline Reforence & $(2,3)$ & (1) & (5) & (6) \\
\hline
\end{tabular}

(a) Thernulynamic data fur the metal carbues at higher temperatures were computed by the method given in "Chemistry and Peallurgy of Mbeellane us Materials", TD-3212 (1955).

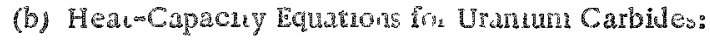

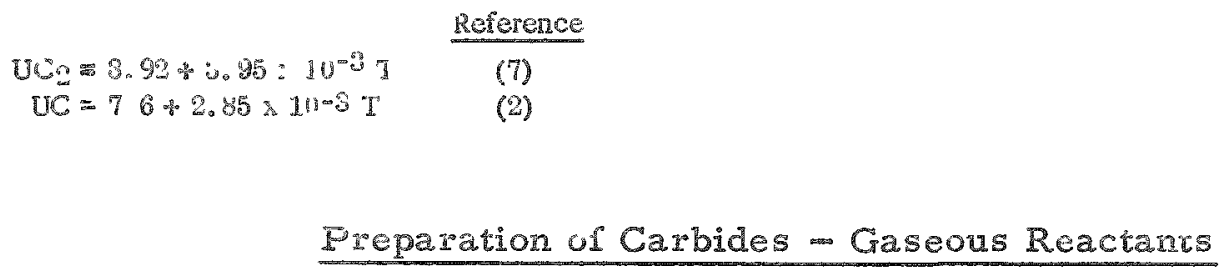

Hydrocarbn gase liate been considered for reduction of both gaseous and condensed uranium phuses. Thu relative reduction potential of the rarious hydrocarbons can be obtaincd by eamination of the data in Table 11. Although the free energy of formation is pooilve ior must of the gases at relatively low temperatures, cracking into 
hydrogen, rarhon, and musaturated hydrocabons does not usually occup wyithout benefit of a catalyst up to relatively high temperatures (approximately $1800 \mathrm{~F}$ ). If cracking does not occur until the reaction takes place, those gases with a higher positive free energy will contribute more driving force for the production of the carbide. Although data have not been reported, the catalytic effect of plutonium, uranium, thorium, or their compounds, on the cracking of the hydrocarbons should be considered in reactions of this type. Also, those materials used in the reaction vessel or purification train should not produce cracking. It is evident that, if cracking occurs before the reaction takes place, the reactants are the fuel compound and carbon in a hydrogen amosphere. In the case of gases such as acetylene, considerable driving force for the production of the carbide would be lost.

TABLE 11. HYDROCARBON REDUCTION POTENTIAL OF FUEL COMPOUNDS(a) STANDARD FREE ENERGY OF FORMATION OF HYDROCARBONS(8)

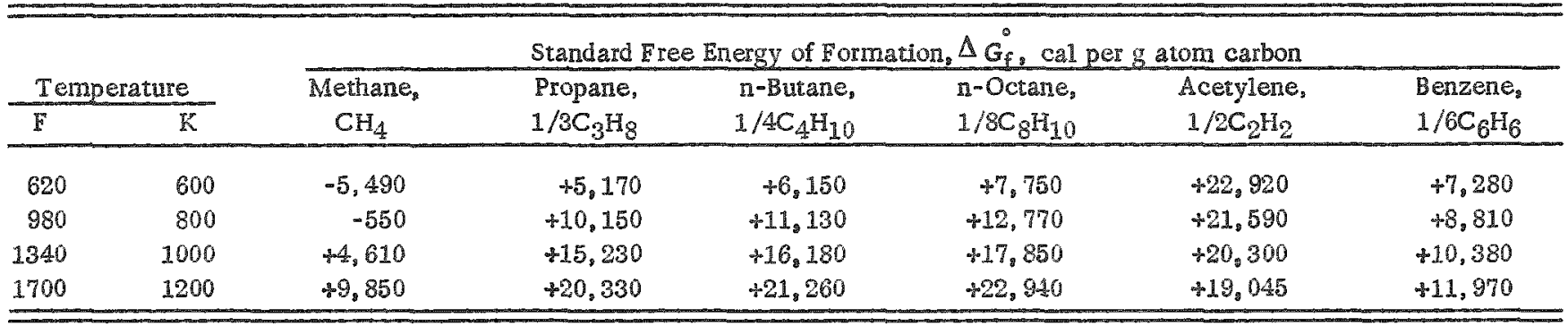

(a) The higher the positive value of $\Delta G_{f}^{\circ}$, the greater is the reducing power of the hydrocarbon. At higher temperatures, the data are unealistic since thermal cracking may occur.

The reduction of UF 6 to UC by hydrocarbons has been considered in detail(9) and some of the results, based on data by Glassner(10), are shown in Table 12. These results indicate that $U F_{4}$ would form as an intermediate product and that, under equilibrium conditions, the reduction of $\mathrm{UF}_{6}$ to UC would not go to completion. Reactions with other halides were not considered. Bromides, chlorides, and iodides are not generally considered for preparation of the carbides, since other fuel compounds are more readily available. However, since $U_{6}$ is used to produce other uranium compounds its use would be desirable if conditions could be found under which UC could be produced from UF6.

\section{Preparation of Carbides - Condensed Phase Reactants}

The most commonly considered reactions for the production of carbides by use of a hydrocarbon gas involve the reaction of the metal, the oxide, or, in some cases, the hydride with methane. The data for these reactions are given in Table 13. Similar results would be expected with other hydrocarbons, although more favorable results would be indicated for those compounds with a higher positive free energy of formation as listed in Table 11.

The reduction of $\mathrm{UF}_{6}$ to $\mathrm{UC}$ by graphite has also been considered(9), and, as indicated in Table 14, the reaction is not favorable. Another reaction which is feasible but which involves the separation of solid products is the reduction of UF6 to UC by calcium carbide and calcium. Data for this reaction are given in Table 15. Since UF 4 will also be reduced no difficulty is encountered because of UF ${ }_{4}$ formation. 
TABLE 12. STANDARD FREE-ENERGY CHANGES OF THE REACTION OF UE 6(g) TO UC(c) SHOWING THE EREE-ENERGY CHANGES OF THE INTERMEDIATE UE $4(c, g, 1)$

The over-all reaction $(9)$ is: $\mathrm{UE}_{6}(\mathrm{~g})+\mathrm{H}_{2}(\mathrm{~g})+\mathrm{CH}_{4}(\mathrm{~g})=\mathrm{UC}(\mathrm{c})+6 \mathrm{HE}(\mathrm{g})$.

\begin{tabular}{|c|c|c|c|c|c|}
\hline \multirow[b]{2}{*}{ Reaction } & \multirow[b]{2}{*}{ Reaction } & \multicolumn{4}{|c|}{ Standard Free-Energy Change, $\Delta G_{T}^{\circ}$ cal } \\
\hline & & $1000 \mathrm{~K}(1340 \mathrm{E})$ & $1200 \mathrm{~K}(1700 \mathrm{E})$ & $1500 \mathrm{~K}(2240 \mathrm{~F})$ & $2073 \mathrm{~K}(3270 \mathrm{~F})$ \\
\hline $1^{(a)}$ & $U F_{6}(g)+H_{2}(g) \rightarrow-U F_{4}\left(c_{8} I\right)+2 H F(g)$ & -69.070 & $-70,690$ & $-71,270$ & $-84,670$ \\
\hline $2^{(b)}$ & $\mathrm{UF}_{6}(\mathrm{~g})+\mathrm{H}_{2}(\mathrm{~g}) \rightarrow \mathrm{UF}_{4}(\mathrm{~g})+2 \mathrm{HF}(\mathrm{g})$ & -- & $-\infty$ & -64.870 & $-97,440$ \\
\hline $3^{(a, c)}$ & $\mathrm{UF}_{4}(\mathrm{c}, 1)+\mathrm{CH}_{4}(\mathrm{~g}) \rightarrow \mathrm{UC}(\mathrm{c})+4 \mathrm{HF}(\mathrm{g})$ & $+83,430$ & $+64,850$ & $+39,090$ & $-8,090$ \\
\hline $4^{(b, c)}$ & $\mathrm{UF}_{4}(\mathrm{~g})+\mathrm{CH}_{4}(\mathrm{~g}) \rightarrow \mathrm{UC}(\mathrm{c})+4 \mathrm{HF}(\mathrm{g})$ & -- & -- & $+32,690$ & $+4,680$ \\
\hline $5(c)$ & $\begin{array}{l}\mathrm{UF}_{6}(\mathrm{~g})+\mathrm{H}_{2}(\mathrm{~g})+\mathrm{CH}_{4}(\mathrm{~g}) \rightarrow \mathrm{UC}(\mathrm{c}) \\
+6 \mathrm{HF}(\mathrm{g})\end{array}$ & $+14,360$ & $-5,840$ & $-32,180$ & $-92,760$ \\
\hline
\end{tabular}

(a) In Reactions 1 and 3 , UF 4 is shown as a liquid at $2073 \mathrm{~K}$, which is above the bolling point of UF 4 . Therefore, this reaction would have to be compressed.

(b) In Reactions 2 and $4, \mathrm{UR}_{4}$ is shown as a gas at $1500 \mathrm{~K}$. UE 4 boils at $1690 \mathrm{~K}_{2}$ and therefore, this reaction would have to be carried out at diminished pressures.

(c) Methane would crack to carbon and hydrogen above $1700 \mathrm{~F}$.

TABLE 13. STANDARD FREE-ENERGY CHANGE OF THE REACTION OE FUEL METALS, OXIDES, AND HYDRIDES WITH METHANE GAS

\begin{tabular}{|c|c|c|}
\hline \multirow[b]{2}{*}{ Reaction } & \multicolumn{2}{|c|}{$\begin{array}{c}\text { Standard Free-Energy Change, } \\
\Delta G_{T,} \text { cal }\end{array}$} \\
\hline & $1000 \mathrm{~K}$ & $1200 \mathrm{~K}$ \\
\hline \multicolumn{3}{|l|}{$\mathrm{UO}_{2}(\mathrm{c})+4 \mathrm{CH}_{4}(\mathrm{~g})=\mathrm{UC}_{2}(\mathrm{c})+2 \mathrm{CO}(\mathrm{g})+8 \mathrm{H}_{2}(\mathrm{~g})$} \\
\hline $\mathrm{UO}_{2}(\mathrm{c})+3 \mathrm{CH}_{4}(\mathrm{~g})=\mathrm{UC}(\mathrm{c})+2 \mathrm{CO}(\mathrm{g})+6 \mathrm{H}_{2}(\mathrm{~g})$ & $+90,380$ & $+66,560$ \\
\hline $\mathrm{ThO}_{2}(\mathrm{c})+4 \mathrm{CH}_{4}(\mathrm{~g})=\mathrm{ThC}_{2}(\mathrm{c})+2 \mathrm{CO}(\mathrm{g})+8 \mathrm{H}_{2}(\mathrm{~g})$ & $+93,910$ & $+53,870$ \\
\hline $\mathrm{PuO}_{2}(\mathrm{c})+3 \mathrm{CH}_{4}(\mathrm{~g}) \Longrightarrow \mathrm{PuC}(\mathrm{c})+2 \mathrm{CO}(\mathrm{g})+6 \mathrm{H}_{2}(\mathrm{~g})$ & $+71,850$ & $+39,550$ \\
\hline $\mathrm{U}(\mathrm{c})+2 \mathrm{CH}_{4}(\mathrm{~g})=\mathrm{UC}_{2}(\mathrm{c})+4 \mathrm{H}_{2}(\mathrm{~g})$ & $-48,220$ & $-58,100$ \\
\hline $\mathrm{U}(\mathrm{c})+\mathrm{CH}_{4}(\mathrm{~g}) \rightleftharpoons \mathrm{UC}(\mathrm{c})+2 \mathrm{H}_{2}(\mathrm{~g})$ & $-22,620$ & $-27,020$ \\
\hline $\operatorname{Th}(c)+2 \mathrm{CH}_{4}(g)=\operatorname{ThC}_{2}(\mathrm{c}) \div 4 \mathrm{H}_{2}(g)$ & $-51,620$ & $-61,580$ \\
\hline $\mathrm{Pu}(\mathrm{c})+\mathrm{CH}_{4}(\mathrm{~g})=\mathrm{PuC}(\mathrm{c})+2 \mathrm{H}_{2}(\mathrm{~g})$ & $-27,610$ & $-32,450$ \\
\hline $2 \mathrm{UH}_{3}(\mathrm{c}) \div 2 \mathrm{CH}_{4}(\mathrm{~g})=2 \mathrm{UC}(\mathrm{c})+7 \mathrm{H}_{2}(\mathrm{~g})$ & \multirow{2}{*}{\multicolumn{2}{|c|}{$\begin{array}{c}\mathrm{UH}_{3} \text { is dissuciated to } \mathrm{U}(\mathrm{c}) \div 3 / 2 \\
\mathrm{H}_{2}(\mathrm{~g}) \text { at these temperatures }\end{array}$}} \\
\hline $2 \mathrm{UH}_{3}(\mathrm{c})+4 \mathrm{CH}_{4}(\mathrm{~g})=2 \mathrm{UC}_{2}(\mathrm{c})+11 \mathrm{H}_{2}(\mathrm{~g})$ & & \\
\hline
\end{tabular}


TABLE 14. THE STAND ARD FREE-ENERGY CHANGE FOR THE REDUCTION OF UFG(g) BY CARBON TO UC(c)

$$
\mathrm{UF}_{6}(\mathrm{~g})+\mathrm{C}(\mathrm{c})=\mathrm{UC}(\mathrm{c})+3 / 2 \mathrm{CF}_{4}(\mathrm{~g})
$$

\begin{tabular}{|c|c|c|c|c|}
\hline \multicolumn{2}{|c|}{ Temperature } & \multirow{2}{*}{$\begin{array}{l}\text { Standard Free-Energy Change, } \\
G^{\circ} \mathrm{T}, \mathrm{cal}\end{array}$} & \multirow{2}{*}{$\begin{array}{l}\log _{10} \\
\text { Equilibrium } \\
\text { Constant, } \\
\log _{10} \mathrm{~K}\end{array}$} & \multirow{2}{*}{$\begin{array}{c}\text { Equilibrium } \\
\text { Conversion of } \\
\text { UF } 6 \text { (g) to UC(c) at } 1 \text { Atr }_{\text {Pressure, per cent }} \\
\end{array}$} \\
\hline$F$ & $\mathrm{~K}$ & & & \\
\hline 3140 & 2000 & $\div 217,050$ & $-23,716$ & $\infty$ \\
\hline 4040 & 2500 & $+209,650$ & $-18,326$ & $6.1 \times 10^{-11}$ \\
\hline
\end{tabular}

TABLE 15. STANDARD FREE -ENERGY CHANGE FOR REDUCTION OF URANIUM FLUORIDES TO UC WITH CaC 2 AND CALCIUM

\begin{tabular}{ccc}
\hline & Free-Energy Change, & Temperature, \\
Reaction & $\mathrm{G}^{\circ} \mathrm{T}, \mathrm{cal}$ & $\mathrm{C}$ \\
\hline $2 \mathrm{UF} 6(\mathrm{~g})+5 \mathrm{Ca}(\mathrm{c}, 1, \mathrm{~g})+\mathrm{CaC}_{2}(\mathrm{c})=2 \mathrm{UC}(\mathrm{c})+$ & $-655,740$ & 727 \\
$6 \mathrm{CaF}_{2}(\mathrm{c}, \mathrm{l})$ & $-550,900$ & 1800 \\
& $-477,820$ & 2227 \\
$2 \mathrm{JF}_{4}(\mathrm{~g})+3 \mathrm{Ca}(\mathrm{c}, 1, \mathrm{~g})+\mathrm{CaC}_{2}(\mathrm{c}) \rightleftharpoons 2 \mathrm{UC}(\mathrm{c})$ & $-283,740$ & 727 \\
$+4 \mathrm{CaF}_{2}(\mathrm{c}, 1)$ & $-274,900$ & 1800 \\
& $-233,820$ & 2227 \\
\hline
\end{tabular}


TABLE 16. STANDARD FREE-ENERGY CHANGE OF REACTIONS FOR THE PREPARATION OF NUCLEAR CARBIDES FROM THEIR CORRESPONDING OXIDES BY THE ACTION OF CARBON

\begin{tabular}{|c|c|c|c|c|c|c|c|c|c|}
\hline \multirow[b]{2}{*}{ Reaction } & \multicolumn{8}{|c|}{ Standard Free-Energy Change, $\Delta G_{T}^{\circ}$, cal } & \multirow{2}{*}{$\begin{array}{l}\text { Equilibrium Partial Pressure of } \\
\text { CO at } 2200 \mathrm{~K} \text {, mm of mercury }\end{array}$} \\
\hline & $900 \mathrm{~K}$ & $1000 \mathrm{~K}$ & $1200 \mathrm{~K}$ & $1400 \mathrm{~K}$ & $1600 \mathrm{~K}$ & $1800 \mathrm{~K}$ & $2000 \mathrm{~K}$ & $2200 \mathrm{~K}$ & \\
\hline $\mathrm{UO}_{2}(\mathrm{c})+3 \mathrm{C}(\mathrm{c}) \neq \mathrm{UC}(\mathrm{c})+2 \mathrm{CO}(\mathrm{g})$ & $+112,060$ & $+104,210$ & $+88,530$ & $+72,980$ & $+57,520$ & $+41,940$ & $+26,350$ & $+10,760$ & 221.7 \\
\hline $\mathrm{ThO}_{2}(\mathrm{c})+4 \mathrm{C}(\mathrm{c}) \Rightarrow \mathrm{ThC}_{2}(\mathrm{c})+2 \mathrm{CO}(\mathrm{g})$ & $+116,900$ & $+108,370$ & $+91,270$ & $+74,320$ & $+57,450$ & $+40,720$ & $+24,080$ & $+11,990$ & 192.7 \\
\hline $\mathrm{PuO}_{2}(\mathrm{c})+3 \mathrm{C}(\mathrm{c}) \rightleftharpoons \mathrm{PuC}(\mathrm{c})+2 \mathrm{CO}(\mathrm{g})$ & $+92,040$ & $+85,680$ & $+69,100$ & $+53,160$ & $+37,250$ & $+21,360$ & $+5,520$ & $-10,320$ & 2471.5 \\
\hline
\end{tabular}

TABLE 17. STANDARD FREE-ENERGX CHANGE FOR THE FORMATION OE CARBIDES BY REACTION OE FUEL METALS WITH CARBON(a)

\begin{tabular}{|c|c|c|c|c|c|c|c|c|}
\hline \multirow[b]{2}{*}{ Reaction } & \multicolumn{8}{|c|}{ Standard Free-Energy Change, $\Delta G_{T}^{\circ}$, cal } \\
\hline & $900 \mathrm{~K}$ & $1000 \mathrm{~K}$ & $1200 \mathrm{~K}$ & $1400 K$ & $1600 \mathrm{~K}$ & $1800 \mathbb{K}$ & $2000 \mathrm{~K}$ & $2200 \mathrm{~K}$ \\
\hline$U(c)+C($ graphite $) \geqslant U C(c)$ & $-18,400$ & $-18,010$ & $-17,170$ & $-16,300$ & $-15,200$ & $-14,600$ & $-14,000$ & $-13,400$ \\
\hline $\mathrm{U}(\mathrm{c})+2 \mathrm{C}(\mathrm{graphite}) \Rightarrow \mathrm{U} \mathrm{C}_{2}(\mathrm{c})$ & $\cdot 2,300$ & $-39,000$ & $-38,400$ & $-37,800$ & $-37,200$ & $-36,600$ & $-36,000$ & $-35,400$ \\
\hline $\mathrm{Th}(\mathrm{c})+2 \mathrm{C}$ (graphite) $\Rightarrow \mathrm{ThC}_{2}(\mathrm{c})$ & $-42,660$ & $-42,400$ & $-41,880$ & $-41,360$ & $-40,840$ & $-40,320$ & $-39,800$ & $-39,280$ \\
\hline$P u(c)+C($ graphite $)=P u C(c)$ & $-24,820$ & $-23,000$ & $-22,600$ & $-22,220$ & $-21,800$ & $-21,400$ & $-21,000$ & $-20,600$ \\
\hline
\end{tabular}

(a) At all temperatures $\mathrm{UH}_{3}$ will decompose to uranium and hydrogen. 
Proparation of Carbides - Snlid-Solid Reactions

The solid-state reactions generally involve the formation of the carbide by reacting the metal, the oxide, the hydride or another carbide with carbon. If extended to a sufficiently high temperature, reactions with the liquid metal may also be considered.

Reactions of carbon with the oxide are listed in Table 16. Because of the relatively low equilibrium pressure of $\mathrm{CO}$, these reactions are usually carried out in vacuo.

Reactions of the metal, either as metal or starting with $\mathrm{UH}_{3}$, with carbon are shown in Table 17.

The reaction of carbon with $\mathrm{UC}$ to form $\mathrm{UC}_{2}$ is considered in Table 18.

\begin{tabular}{|c|c|}
\hline $\begin{array}{r}\text { TABLE 18. } \\
\mathrm{s} \\
0\end{array}$ & $\begin{array}{l}\text {-ENERG Y CHANGE } \\
\text { ON: } \\
=\mathrm{UC}_{2}(\mathrm{c})\end{array}$ \\
\hline $\begin{array}{l}\text { Temperature, } \\
\mathrm{K}\end{array}$ & $\begin{array}{c}\text { Free-Energy Change } \\
\Delta G_{\mathrm{T}}^{\circ} \text { cal }\end{array}$ \\
\hline 900 & $-20,900$ \\
\hline 1000 & $-20,990$ \\
\hline 1200 & $-21,230$ \\
\hline 1400 & $-21,500$ \\
\hline 1600 & $-22,000$ \\
\hline 1800 & $-22,000$ \\
\hline 2000 & $-22,000$ \\
\hline 2200 & $-22,000$ \\
\hline
\end{tabular}

Other reactions which have been considered, but which do not appear favorable below about $1800 \mathrm{C}$ include: (1) $\mathrm{UF}_{4}+\mathrm{SiC} \rightleftharpoons \mathrm{UC}+\mathrm{SiF}_{4}$ and (2) $\mathrm{US}+\mathrm{C}=\mathrm{UC}+1 / 2 \mathrm{~S}_{2}$. The first of these reactions probably would be complicated by the formation of a uranium silicide.

\section{$\underline{\text { References }}$}

(1) Strasser, A., "Carbide Fuel Development", NDA-2140-2 (January 11, 1960 ).

(2) Tripler, A. B., Snyder, M. J., and Duckworth, W. H., "Further Studies of Sintered Refractory Uranium Compounds", BMI-1313 (January 27, 1959).

(3) Bowman, M., LASL, Personal Communication to Strasser, A., NDA, and cited in Reference (1).

(4) Rossini, F. D. "Selected Values of Chemical Thermodynamic Properties", Natl. Bur. Standards (U. S.) Circ. No. 500 (1952). 
(5) Kubachewski, O., and Evans, E.L.I., Metallurgical Thermochemistry, Pergamon Press, New York (1958)。

(6) Brewer, L., Bramley, L., Gilles, $P_{0} W_{*}$, and Lofgren, N. Lo, "The Thermodynamic Properties and Equilibria at High Temperatures of the Compounds of Plutonium", BC-88 (October 10, 1947).

(7) Katz, J. J., and Rabinowitch, E。, The Chemistry of Uranium, Part 1, McGrawHill Book Company, Inc., New York (1951)。

(8) Rossini, F. D., et al. "Selected Values of Properties of Hydrocarbons", Natl. Bur. Standards (U. S.) Circ. No. 461 (1947).

(9) Ward, J. J., and Cunningham, G. W. "Reduction of Uranium Hexafluoride Gas to Uranium Monocarbide", to be published.

(10) Glassner, A., "The Thermochemical Properties of the Oxides, Fluorides, and Chlorides to $2500 \mathrm{~K} "$ ", ANL-5750 (1957)。

\section{PREPARATION BY CHEMICAL REACTIONS}

D. E. Kizer and D. L. Keller

Introduction

Various methods other than arc melting have been investigated experimentally for the preparation of uranium carbides. These include reaction of uranium with hydrocarbons and the reaction of uranium and uranium oxides with carbon. The thermodynamics of the reactions to be discussed can be found in the previous section.

\section{Reaction of Uranium With Hydrocarbons}

The cracking of alkane hydrocarbons to hydrogen, carbon, and alkenes must be considered in any high-temperature reactions involving these compounds. Thermodynamic calculations predict that the cracking of alkanes should occur at relatively low :emperatures, some at room temperature. However, it is known that many of the hydrozarbons are stable at temperatures on the order of $2000 \mathrm{~F}$, and in many cases catalysts are required to crack the compounds at temperatures well above their predicted decomposition temperature.

In the reactions involving the production of UC, it is not known whether uranium acts to any degree as a catalyst. If no catalytic effect is obtained, the reactions are carried out at a temperature at which the hydrocarbon gas is stable. The importance of whether or not the hydrocarbon cracks may be illustrated by comparing the reactions: i) $\mathrm{U}+\mathrm{CH}_{4} \rightarrow \mathrm{UC}+2 \mathrm{H}_{2}$ and (2) $\mathrm{U}+\mathrm{C} \rightarrow \mathrm{UC}$. At $900 \mathrm{~K}$ the free-energy change for the sirst reaction is $-23,130 \mathrm{cal}$, and for the second reaction it is $-20,550$ cal. Thus, in the 
second reaction the additional driving force provided by the derompnsition of the methane is lost, and, except as a matter of convenience in adding reactants, the same results could be obtained by reacting carbon and uranium in a hydrogen atmosphere.

Uranium-Methane Reaction

The reaction of uranium with methane, $\mathrm{U}+\mathrm{CH}_{4} \rightarrow \mathrm{UC}+2 \mathrm{H}_{2}$, has been successfully used to produce UC of near stoichiometric composition. (1) Nibbled uranium or uranium turnings and powder have been used as the starting material. The uranium should be pickled in a 50:50 nitric acid-water solution to remove oxide, rinsed thoroughly in water and dried in alcohol or acetone. The cleaned uranium should then be quickly transferred to a vacuum chamber to limit oxidation. After thorough outgassing at 250 to $300 \mathrm{C}$ the metal is hydrided at 200 to $250 \mathrm{C}$ to produce a fine uranium powder. This powder is then reacted with methane gas at a pressure of less than $1 / 2 \mathrm{~atm}$ at a temperature of 650 to $700 \mathrm{C}$. After several charges of methane have been added it is beneficial to drop the temperature and hydride the unreacted metal. This is done to maintain a loose mass so that the reaction with methane will occur freely when the temperature is again raised. The completion of the reaction is indicated when no decrease in pressure occurs as the reaction tube is allowed to cool to room temperature after it has been evacuated and filled with hydrogen at $650 \mathrm{C}$. If a decrease in pressure is noted, hydriding, breaking down of the hydride, and reaction with methane are repeated until the reaction with methane is complete.

Uranium carbide prepared at Battelle, by the method described above, has a typical chemical analysis of $4.88 \mathrm{w} / 0$ total carbon and $0.31 \mathrm{w} / 0$ free carbon. An X-ray diffraction pattern of this material shows a very strong UC pattern, a faint UC, pattern, and a diffuse medium-strong pattern of an unknown.

Litz (2) reports that $\mathrm{X}$-ray diffraction patterns of UC prepared by the above method indicate that metallic uranium and crystalline graphite are absent from the product. He reports a typical analysis as being $94.8 \mathrm{w} / 0$ uranium.

Kalish, Bowman, and Crane(3) also report studies of the uraniummethane reaction. Their technique involves passing methane at a rate of $5 \mathrm{ft}^{3}$ per hr over uranium metal powder and uranium hydride starting material at a temperature of $700 \mathrm{C}$. After $2 \mathrm{hr}$ at temperature with a starting material of fine uranium powder, $\mathrm{X}$-ray diffraction patterns indicated UC and uranium were present in the product. A duplicate experiment using uranium hydride as a starting material instead of fine uranium powder yielded only $\mathrm{UC}$, as indicated by an $\mathrm{X}$ - ray diffraction pattern.

A patent has been issued to $R$. W. Fisher(4) describing the production of uranium monocarbide by heating uranium metal in the range of 400 to $1125 \mathrm{C}$ in contact with methane, or an aliphatic hydrocarbon. The amount of hydrocarbon employed is adjusted so that its carbon content corresponds to about $4.8 \mathrm{w} / 0$ of the uranium metal.

\section{Uranium-Propane Reaction}

Kizer ${ }^{(1)}$ has employed the $\mathrm{U}+\mathrm{CH}_{8} \rightarrow \mathrm{UC}+4 \mathrm{H}_{2}$ reaction. Fine uranium powder prepared by the thermal decomposition of uranium hydride was reacted with propane at $538 \mathrm{C}$ to produce UC having a total-carbon analysis of $4.68 \mathrm{w} / 0$ and a free-carbon analy sis of $0.32 \mathrm{w} / 0$. An $\mathrm{X}$-ray diffraction pattern of the product indicated a very strong but 
diffuse pattern of UC and a very faint pattern of unknown. No free-uranium or graphiticcarbon lines appeared in the pattern. The procedure for the propane reaction was the same as previously described for the methane reaction except that the chamber was filled with propane at a pressure of $1 / 4$ atm or less, and the reaction was carried out at a temperature of $538 \mathrm{C}$. Increasing the temperature of the reaction above $538 \mathrm{C}$ to $650 \mathrm{C}$ had no noticeable effect on the reaction rate. The completion of the reaction was indicated when no decrease in pressure occurred as the reaction tube was allowed to cool to room temperature after it was evacuated and filled with hydrogen at $538 \mathrm{C}$. If a decrease in pressure was noted, hydriding, breaking down of the hydride under vacuum, and reaction with propane was repeated until the reaction with propane was complete.

\section{Uranium-Acetylene Reaction}

The reaction of uranium with acetylene to form $\mathrm{UC}, 2 \mathrm{U}+\mathrm{C}_{2} \mathrm{H}_{2} \rightarrow 2 \mathrm{UC}+\mathrm{H}_{2}$, has been reported by Litz $(2)$ to have an appreciable rate at $500 \mathrm{C}$. The product is reported to contain relatively large quantities of carbon, making it impractical for producing pure stoichiometric UC.

Reaction of Uranium Oxides With Carbon

The standard free-energy change for the reaction $\mathrm{UO}_{2}(\mathrm{c})+3 \mathrm{C}(\mathrm{c}) \rightleftharpoons \mathrm{UC}(\mathrm{c})+2 \mathrm{CO}(\mathrm{g})$ is $+16,000 \mathrm{cal}$ at $1800 \mathrm{C}$. Experimental results indicate that the reaction of $\mathrm{UO}_{2}$ with carbon can take place at low temperatures if the $C O$ partial pressure is maintained low enough. If $\mathrm{U}_{3} \mathrm{O}_{8}$ is used instead of $\mathrm{UO}_{2}$ for the formation of UC by combining with carbon, the above reaction would still control as the $\mathrm{U}_{3} \mathrm{O}_{8}$ probably goes to $\mathrm{UO}_{2}$ at a temperature lower than that required for the beginning of the $\mathrm{UO}_{2}$-carbon reaction. This as sumption is further verified by experimental data reported by Litz(2). It was observed that after the initial evolution of absorbed gases during vacum heating of $\mathrm{U}_{3} \mathrm{O}_{8}$-carbon mixtures, at relatively low temperature, no further gas evolution of sufficient magnitude to increase the pressure in the system occuried until the temperature reached $1000 \mathrm{C}$. A second stage of gas generation occurred at $1400 \mathrm{C}$. When UO $\mathrm{U}_{2}$ was used instead of $\mathrm{U}_{3} \mathrm{O}_{8}$ the lower temperature stage was not observed.

Mixes of the stoichiometric composition of UC have been prepared from $\mathrm{UO}_{2}$ and carbon and from $\mathrm{U}_{3} \mathrm{O}_{8}$ and carbon by ball milling or grinding and then reacting the mixture in vacuum at temperatures as high as $2100 \mathrm{C}$. Considerable outgassing has been reported at temperatures as low as $1300 \mathrm{C}$ ( 15 ) When the reaction temperature was increased to $1500 \mathrm{C}$ and held until a vacuum of $1 \mu$ was obtained, the $\mathrm{X}$-ray diffraction pattern of the product indicated phases of $\mathrm{UO}_{2}, \mathrm{UC}$, and a very faint pattern of unknown. Similar results have been reported for reactions run $10 \mathrm{hr}$ at $1300 \mathrm{C}$. (3) A mixture of $\mathrm{UO}_{2}$-carbon and UC has been reported after vacuum reacting similar mixes at temperatures as high as $2100 \mathrm{C} .(6,7)$ It has been reported that a temperature of $2500 \mathrm{C}$ is necessary to obtain dense, homogeneous uranium carbides by vacuum reaction of uranium oxide-carbon mixtures.(8)

A patent describing the fomation of uranium carbides of low carbon content lless than $10 \mathrm{w} / 0$ ) from the oxides $\mathrm{UO}_{2} \mathrm{OP} \mathrm{U}_{3} \mathrm{O}_{8}$ and carbon has been is sued to Wilhelm and Daane. (9) In one of the examples cited, a mixture of finely powdered $\mathrm{UO}_{2}$ and graphite was first pressed at 26 tsi to the form of a bar, $1 / 2$ by $1 / 2$ by 2 in, and heated to $2300 \mathrm{C}$ for $20 \mathrm{~min}$ in a graphite crucible. The product had a composition of UC $1.27^{\circ}$ 
Report No. BMI-1441

UC-25 Metallurgy and Ceramics (TID-4500, 15th Ed.)

Contract No. W $-7405 m e n g-92$

\title{
AN EVALUATION OF DATA ON NUCLEAR CARBIDES
}

\author{
Edited by \\ Frank A. Rough \\ Walston Chubb
}

May 31, 1960

BATTELLE MEMORIAL INSTITUTE

$505 \mathrm{King}$ Avenue

Columbus 1, Ohio 


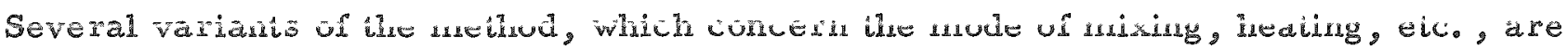
covered by this patent.

The reaction $\mathrm{UO}_{2}+4 \mathrm{C} \rightarrow \mathrm{UC}_{2}+2 \mathrm{CO}$ has allso been studied for the formation of $\mathrm{UC}_{2}$. Similar $\mathrm{UO}_{2}$ and carbon contamination in the product was reported as for the uranium oxide reaction reported above. The reaction was accomplished by heating $20 \mathrm{~g}$ of lampblack and $80 \mathrm{~g}$ of $\mathrm{UO}_{2}$ in a graphite crucible after pressing at $80 \mathrm{tsi}$. The reaction time was $1-1 / 2$ hr at $2100 \mathrm{C} .(10)$ The product was a mixture of excess lampblack and small $\mathrm{UC}_{2}$ nodules not clearly separable. Daane, et al., report similar results. (8)

\section{Reaction of Uranium Metal With Carbon}

Several techniques have been investigated for the direct combination of uranium with carbon to form $\mathrm{UC}_{2}$ or UC. Brett, Law, and Livey have prepared $\mathrm{UC}_{2}$ by sintering uranium-graphite powder cores at $1500 \mathrm{C}(11)$ according to the $U+2 \mathrm{C} \longrightarrow \mathrm{UC}_{2}$ reaction. A minimum sintering temperature of $1500 \mathrm{C}$ is reported necessary to eliminate the presence of UC in the product. Rubenstein and Kopelman(10) describe the preparation of $\mathrm{UC}_{2}$ ingots by melting uranium in a thick-walled graphite crucible. Free carbon was found to be minimized by keeping the temperature of the melt from rising above $2375 \mathrm{C}$. Carbon analyses of 8.38 to 8.78 w/o were reported for the ingot. Free graphite varied from 1.23 to $3.08 \mathrm{w} / 0$.

The formation of UC by the direct combination of uranium plus carbon, $\mathrm{U}+\mathrm{C} \rightarrow$ UC, has been investigated by several workers. Various methods yield a product varying from fine powder to dense UC pellets.

Uranium monocarbide powder has been prepared by Daane, Spedding, and Wilhelm( 8$)$ and Chiotti (12) by mixing graphite and uranium hydride powder. The uranium hydride and graphite were thoroughly mixed, heated slowly to $900 \mathrm{C}$, and sintered at 1600 to 1700 C. No analysis of the product was reported.

A patent has been is sued to Newton and Johnson(13) for the preparation of compounds of uranium and nonmetals. A process is described for preparing a compound of a nonmetal and uranium by reacting uranium hydride with the vapors of a compound of hydrogen and a nonmetal, such as arsenic, boron, carbon, nitrogen, phosphorus, selenium, sulfur, and tellurium.

Litz $^{(2)}$ investigated the feasibility of preparing UC by heating uranium-carbon mixes in beryllium oxide crucibles to $1800 \mathrm{C}$. The product was a sintered mass containing free metal admixed with graphite. Higher temperatures resulted in excessive crucible attack. When a graphite crucible was used instead of a beryllium oxide crucible, the formation of some $\mathrm{UC}_{2}$ resulted.

Methods of preparing dense UC compacts by extruding or hot compacting uraniumcarbon mixes followed by reacting to form UC by sintering at high temperatures are also discussed in a later section of this report. 
Thorium and Plutonium Carbides

Information is not available in the literature on the preparation of thorium or plutonium carbides by chemical reactions; however, the thermodynamics of possible reactions leading to the formation of thorium and plutonium carbides were discussed in the previous section.

\section{Discussion}

There are many variables to consider in the evaluation of the economics of various methods of producing uranium carbide for fuel fabrication. At the present time, it is possible oniy to point out some of the advantages and disadvantages of different processes. Basically, there are two needs to be met in the production of UC for fuelelement fabrication: (1) production of powders of UC suitable for powder fabrication processes and (2) production of UC in the form of chunk or sinter cake suitable for feed material in the casting process. A process which would produce carbide directly from uranium hexafluoride would be highly desirable from the point of view of costs.

The reaction of hydrocarbons with $\mathrm{UH}_{3}$ or fine uranium metal powder to produce UC powder has been investigated only on a laboratory scale, but the powders produced. have been evaluated to some extent. The technique of producing UC powder by reacting fine uranium powder with methane yields a powder with a particle size in the neighborhood of $10 \mu$ or less. This powder is not extremely pyrophoric; it can be handled for short periods of time in air, although it is advisable to maintain a protective atmosphere wherever possible. There is some indication that the UC powder produced by reacting fine uranium metal powder with methane or propane is more desirable for sintering to high densities than powders produced by other techniques.

In the reaction of uranium oxides with carbon to produce UC, large vacuumpumping capacities appear necessary to evacuate the large quantity of CO liberated during the reaction. Temperature from 1300 to $2100 \mathrm{C}$ are reported to be necessary to drive the reaction. This process is being considered commercially; however, difficulty may be encountered in separating the products if the reaction does not go to completion. There appears to have been little evaluation conducted on the carbide produced by the reaction. Its suitability as feed material for casting has not been evaluated. Similarly, it has not been seriously evaluated as a source of powder for powder-metallurgy processes.

Several other processes have been considered by the authors, based upon the available thermodynamic data, as indicated in the section on thermodynamics. The reaction which appears most attractive thermodynamically is one involving reduction of UF 6 with calcium and calcium carbicle to produce UC. Some of the disadvantages of such a process would be the need for separation of the UC from the other reaction products and the unavailability of production quantities of pure calcium carbide. However, if economic production is to be achieved, direct reduction from the fluoride is obviously desirable, and potential processes of this type should be studied. 
Reírences

(1) Kizer, D., BMI, Unpublished Information.

(2) Litz, L. $M_{\bullet}$, "Uranium Carbides - Their Preparation, Structure, and Hydrolysis", Ph. D. Dissertation, The Ohio State University, AEC Document NP-1453 (1948).

(3) "Nuclear Fuel Research Laboratories Fuel Cycle Development Program Quartarly Progress Report No. 1 for Period Ending September 30, 1959", NYO-2684 (October 19, 1959), pp 19-38.

(4) Fisher, R. W., U. S. Patent No. 2,580,349 (December 25, 1951).

(5) Dayton R. W., and Tipton, E. R., Jr., "Progress Relating to Civilian Applice tions During December, 1959", BMI-1403 (January 1, 1960), p 58.

(6) Murray, P., and Williams, J. , "Ceramic and Cermet Fuels", Proceedings of the Second United Nations International Conference on the Peaceful Uses of Atomic Energy, Geneva (1958), Vol 6, A/Conf. 15/P/318, pp 538-50.

(7) Quarterly Report for October, November, and December, 1957", ANL-5837 (1958).

(8) Daane, A. H. , Spedding, F. H. , and Wilhelm, H. A., "The Preparation and Fabrication of the Carbides of Uranium", ISC-11 (December 22, 1947).

(9) Wilhelm, H. A., and Daane, A. H., U. S. Patent No. 2, 448, 479 (August 31, 1948).

(10) Rubenstein, H. S., and Kopelman, B. , "Preparation of Discrete Particles of Uranium Nitride and Carbide for Reactor Elements", SEP-56 (May 4, 1951).

(11) Brett, No, Law, D. , and Livey, D. T. , "Some Investigations on the UraniumThorium-Carbon System", AERE-M/R-2574 (June, 1958).

(12) Chiotti, P. , "Summary of Research on Experimental Refractory Bodies of HighMelting Nitrides, Carbides, and Uranium Dioxide", AECD-3204 (July 16, 1951).

(13) Newton, A. S., and Johnson, O., U. S. Patent No. 2,534,676 (December 19, 1950). 


\section{MELTING AND CASTING}

B. C. Boesser and E. Foster

Introduction

The first castings of uranium carbide were made by the reaction of $\mathrm{UO}_{2}$ and $\mathrm{graph}$ ite to form $\mathrm{UC}_{2} \cdot$ (1) Mallinckrodt $\mathrm{UO}_{2}$ and high-purity graphite in a ratio of 5.62 to 1 were packed into a graphite crucible and induction heated to 2100 to $2300 \mathrm{C}$, where reaction between the $\mathrm{UO}_{2}$ and graphite occurred. After the evolution of $\mathrm{CO}_{2}$ gas was essentially complete, the temperature was raised to $2500 \mathrm{C}$, and a plunger in the bottom of the crucible was pulled, allowing the molten carbide to pour into a graphite mold directly under the crucible. The melting was done in a covered crucible without a protective atmosphere. The $\mathrm{UC}_{2}$ casting produced was sound, homogeneous, and possessed a density of $10.8 \mathrm{~g}$ per $\mathrm{cm}^{3}$. Alloys containing 7 to $9.2 \mathrm{w} / 0$ carbon were made in a similar crucible without a mold. A 5.7 to 1 ratio of $\mathrm{UO}_{2}$ to carbon gave a $\mathrm{UC}_{2}$ ingot which contained $9.15 \mathrm{w} / 0$ carbon; a 7.9 to 1 ratio resulted in an ingot containing $7.21 \mathrm{w} / 0$ carbon. It is not practical to produce uranium monocarbide by induction melting in a graphite crucible, since UC reacts very rapidly with the crucible, forming $\mathrm{UC}_{2}$.

\section{Melting Techniques}

All three of the stable carbides of uranium have been produced and cast by nonconsumable arc meling under a helium or argon atmosphere. (2-9) Metallic uranium and graphite are charged into an inert-electrode arc furnace equipped with a water-cooled copper hearth. The electrode tips may be either graphite or tungsten. Graphite tips have a tendency to raise the carbon content of the melt; however, tungsten tips have a tendency to erode, resulting in contamination of the charge. Charges are usually melted six or seven times. The buttons are turned over between melts to insure good homogeneity. Castings containing from 2.2 to $10 \mathrm{w} / 0$ carbon have been produced by this method. Alloys containing less than 4.8 w/o carbon show free uranium in their microstructures. The microstructures of alloys containing $4.8 \mathrm{w} / 0$ carbon show 100 per cent $\mathrm{UC}$, and those containing more than $4.8 \mathrm{w} / 0$ carbon and less than $9.1 \mathrm{w} / 0$ carbon show either UC with acicular $\mathrm{UC}_{2}$ or $\mathrm{UC}_{2}$ with acicular UC, according to the composition. Castings of $9.16 \mathrm{w} / 0$ carbon are 100 per cent $\mathrm{UC}_{2}$. Only by heat treating is $\mathrm{U}_{2} \mathrm{C}_{3}$ produced. Typical microstructures of as-cast and heat-treated alloys are shown in Figure 27.

\section{Casting Techniques}

Small cylindrical UC castings, up to $3 / 4 \mathrm{in}$. in diameter by $1-3 / 4 \mathrm{in}$. long, have been made by "drop casting" in a helium atmosphere.(2) A thin-walled graphite thimble mold is suspended in a copper support block by an integral graphite collar inside an arcmelting furnace. A photograph of the mold is shown in Figure 28. A 100-g arc-melted. button is placed on the mouth of the mold, and most of the button is melted by a lowcurrent arc. By increasing the current and holding the arc directly over the mouth of the mold, the button is melted through and dropped into the mold. The castings produced 


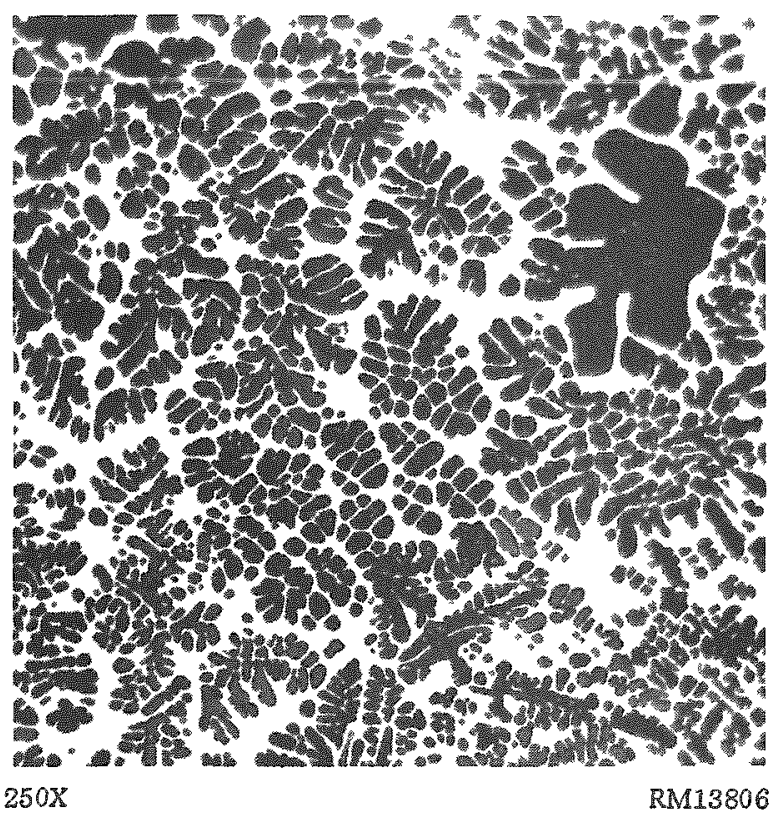

Uranum-2.2 w/o Carbon As Cast

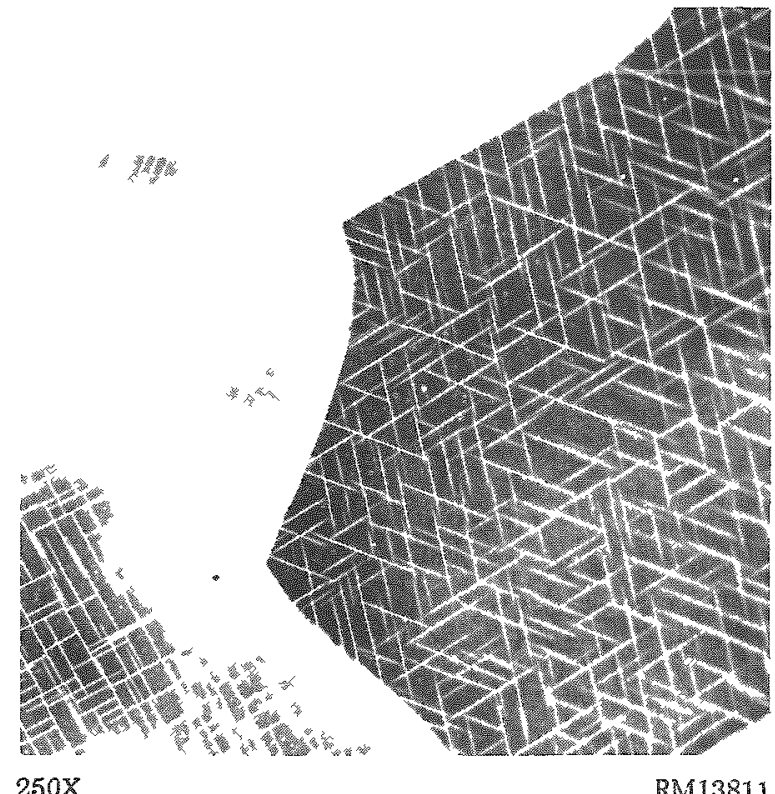

Uranum-5.0 w/0 Carbon As Cast

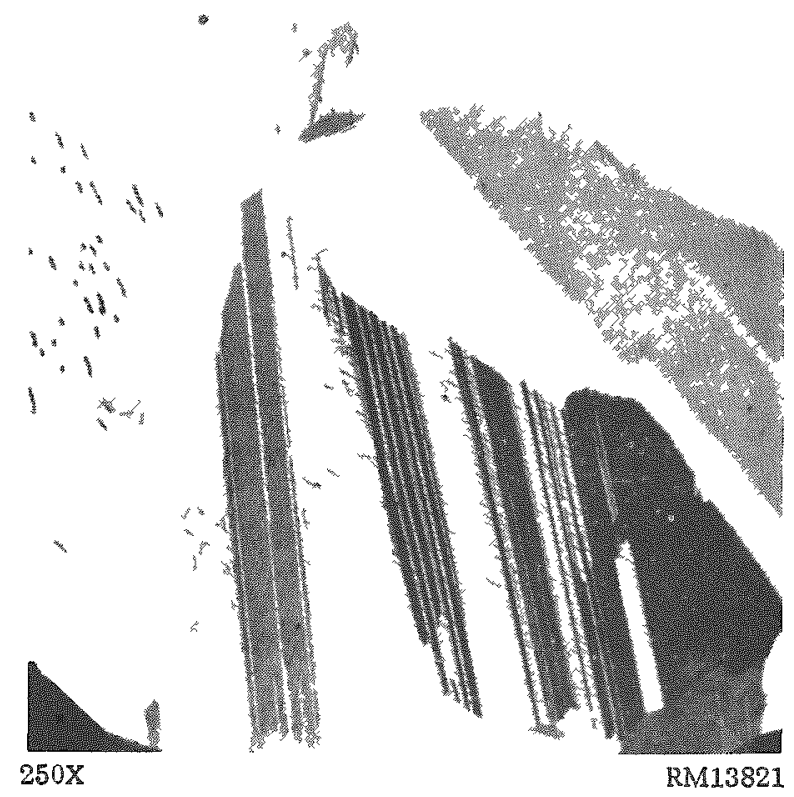

Uranum-8.5 w/o Carbon As Cast

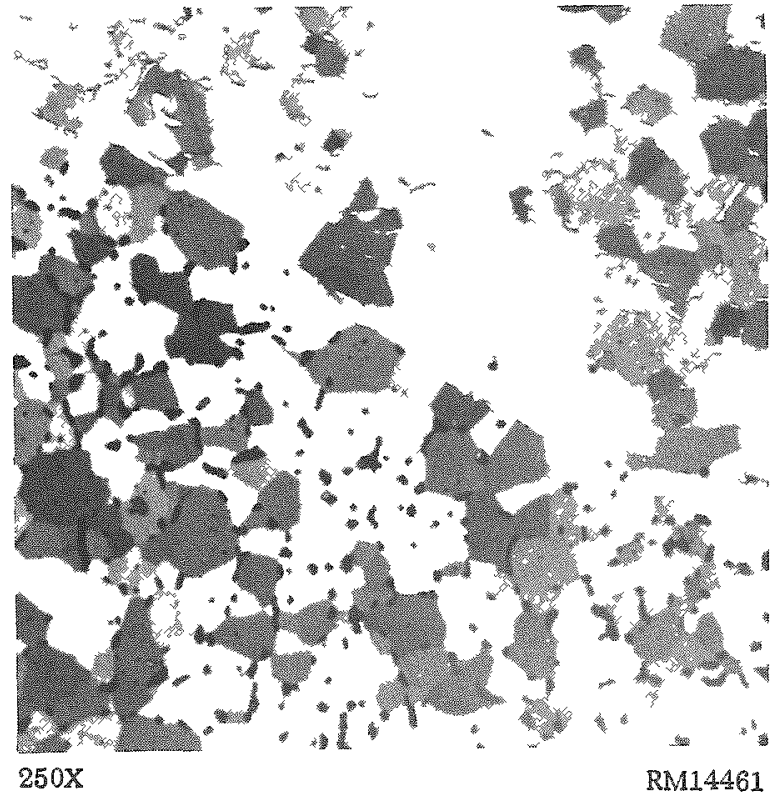

Uramium-7.0 w/o Carbon Annealed 1 in at $1650 \mathrm{C}$

FIGURE 27. TYPICAL MICROSTRUCTURES OF URANIUM CARBON ALLOTS 

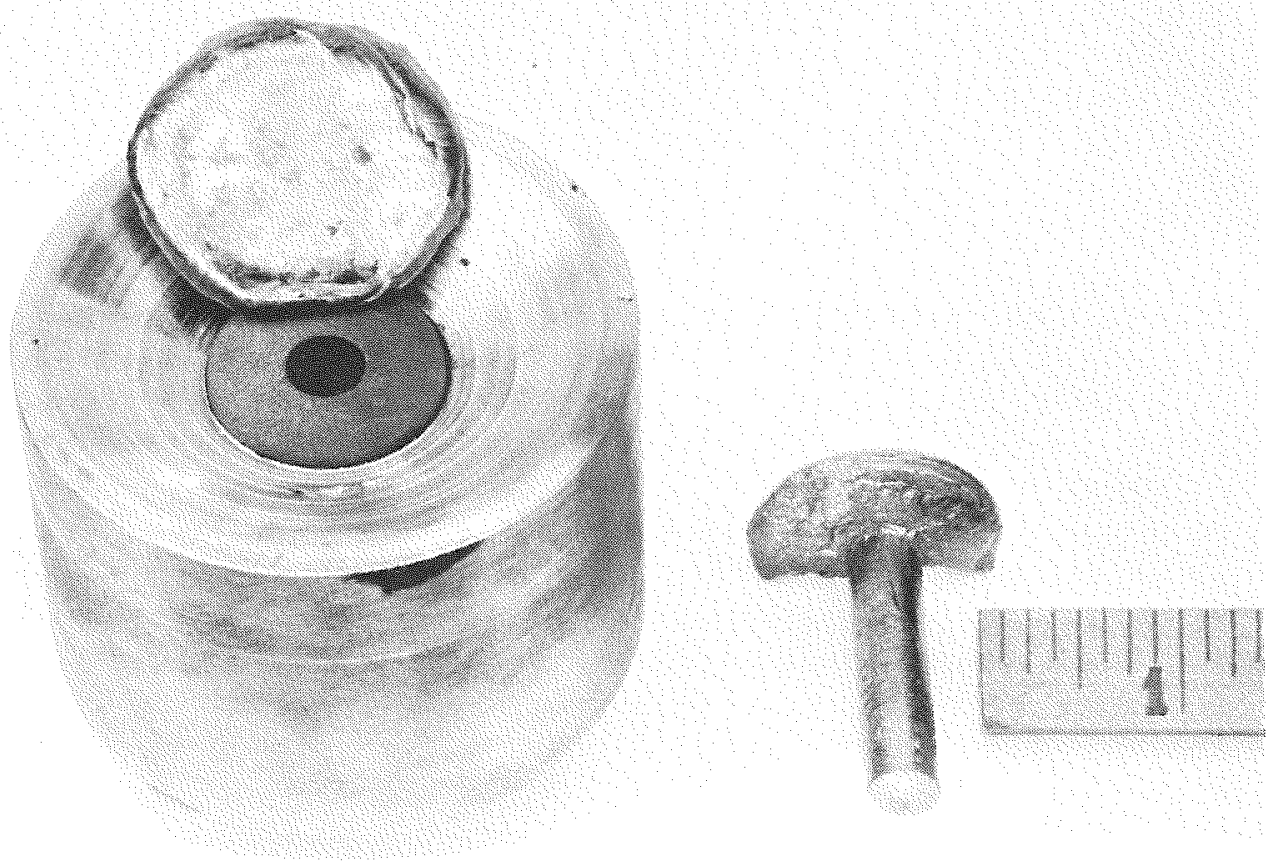

N51385
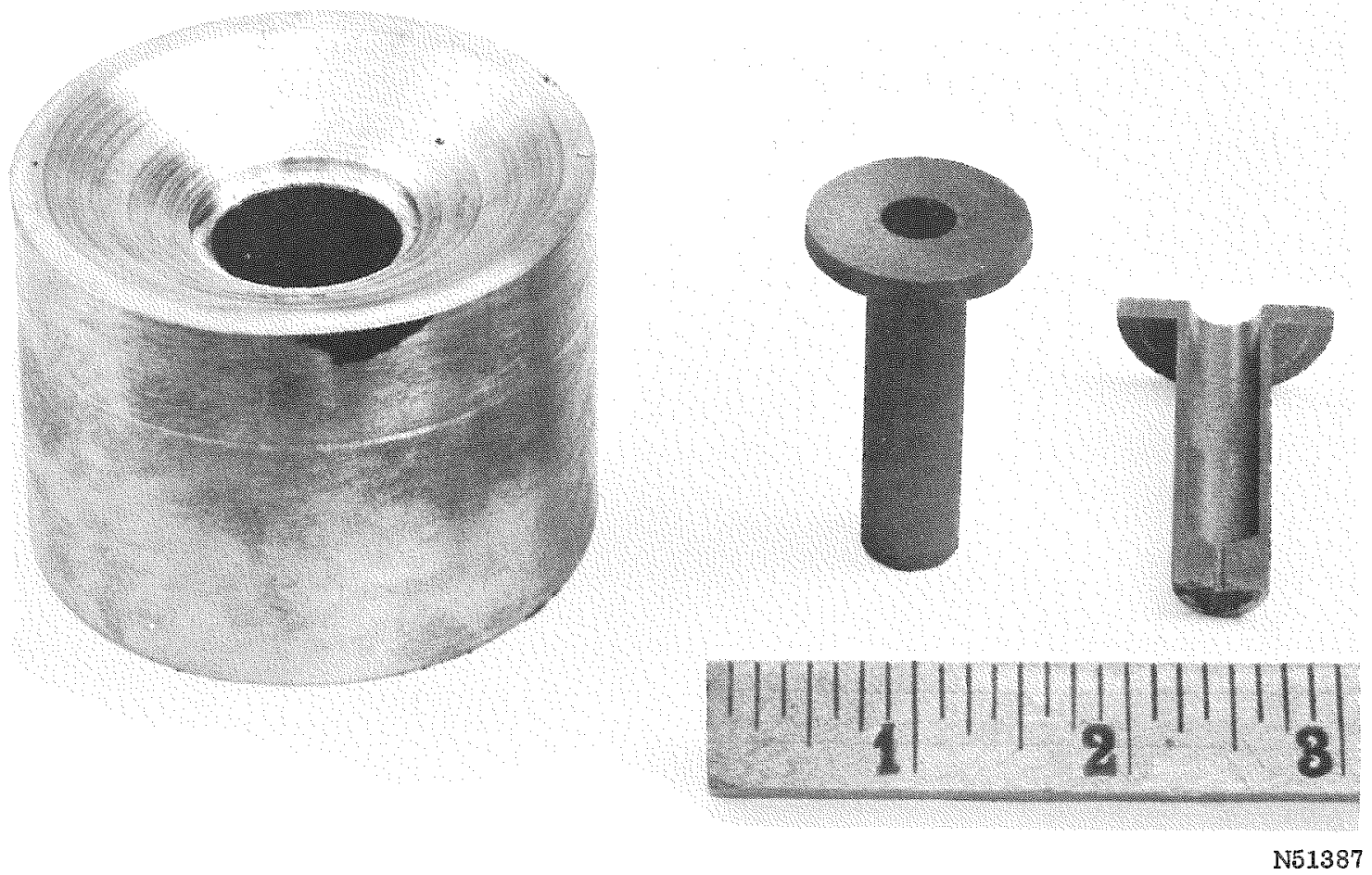

FIGURE 28. PHOTOGRAPH OF TYPICAL DROP-CASTING MOLD SETUP, CHARGE, AND CASTING 
by this method, as shown in Figure 29, are well formed and free of cracks. The reproducibility of this technique is very good, and the castings show good uniformity from top to bottom. Analyses of four typical small castings produced by the drop-casting technique are given in Table $19 .(3)$

TABLE 19. ANALYSES OF SMALL CAST UC SHAPES PREPARED BY DROP-CASTING TECHNIQUES

\begin{tabular}{ccc}
\hline $\begin{array}{c}\text { Casting } \\
\text { Identification(2) }\end{array}$ & $\begin{array}{c}\text { Location of } \\
\text { Sample(b) }\end{array}$ & $\begin{array}{c}\text { Carbon Content, } \\
\text { w/o }\end{array}$ \\
\hline 1 & Skull & 5.00 \\
& Top & 5.00 \\
& Bottom & 4.96 \\
2 & Skull & 4.90 \\
& Top & 4.92 \\
& Bottom & 4.87 \\
3 & Skull & 4.88 \\
& Top & 4.90 \\
& Bottom & 4.94 \\
4 & Skull & 5.02 \\
& Top & 4.95 \\
& Bottom & 4.92 \\
\hline
\end{tabular}

(a) All castings were $5 / 8$ in. in diameter by $2-1 / 2$ in. long.

(b) The sample location referred to as "sku11" is in the ropmost portion of the tack-shaped drop casting.

The sample location referred to as "top" is in the top of the cylindrical section of the drop casting.

The sample location referred to as "bottom" is in the bottom of the cylindrical section of the drop casting.

Drop-casting techniques have been used to prepare castings up to 0.8 in. in diameter and 6 in. long. (4) The process used is similar to that described above except that a solid graphite hearth is employed. Difficulties have been encountered in controlling the composition of castings made from this hearth, but it is believed that this problem can be solved.

Large cylindrical UC castings up to $2 \mathrm{in.}$ in diameter by $8 \mathrm{in.}$ long have been made by a skull-type arc-melting procedure using an inert atmosphere.(10,11) A large UC skull is prepared in a water-cooled copper crucible from uranium and commercial graphite electrode stock by melting small charges. Metallic uranium and graphite are placed on top of the completed skull and melted at 3600 amp and $20 \mathrm{v}$, using a graphite electrode tip. When a large molten pool has formed, it is poured quickly into an induction-heated graphite mold. Large, sound castings of several shapes have been produced using this method. A photograph of several of these shapes is shown in Figure 30. Surface quality and homogeneity are very good. Compositional variations from melt to melt exceed those found in drop-cast material ( $\pm 0.1 \mathrm{w} / 0$ carbon for the drop castings as compared with $\pm 0.3 \mathrm{w} / 0$ carbon for material made by the skull-casting technique). It has been established that a major portion of this latter variation is caused by inhomogeneities that exist 


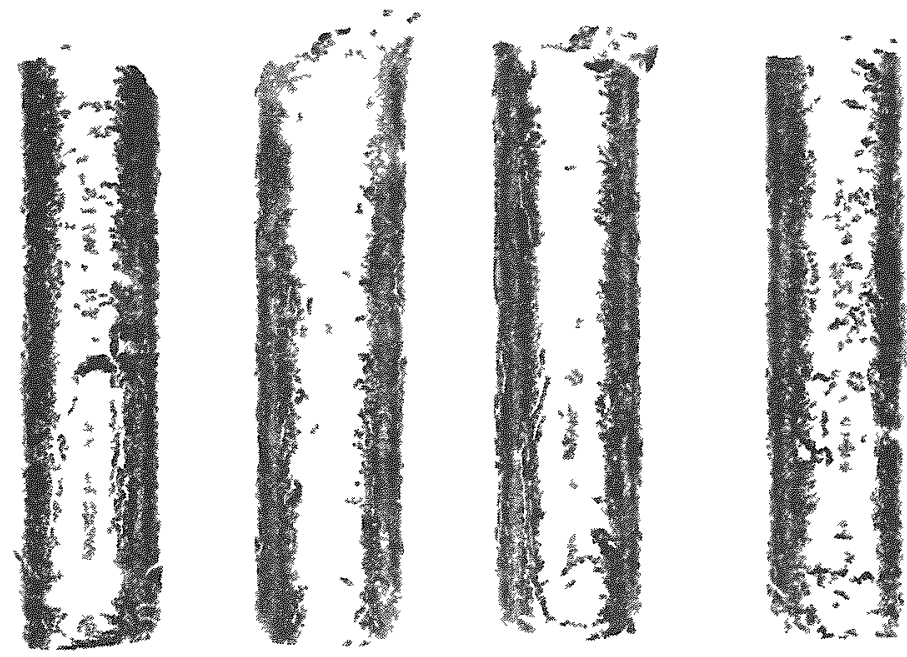

N14372

a. A\& Cas

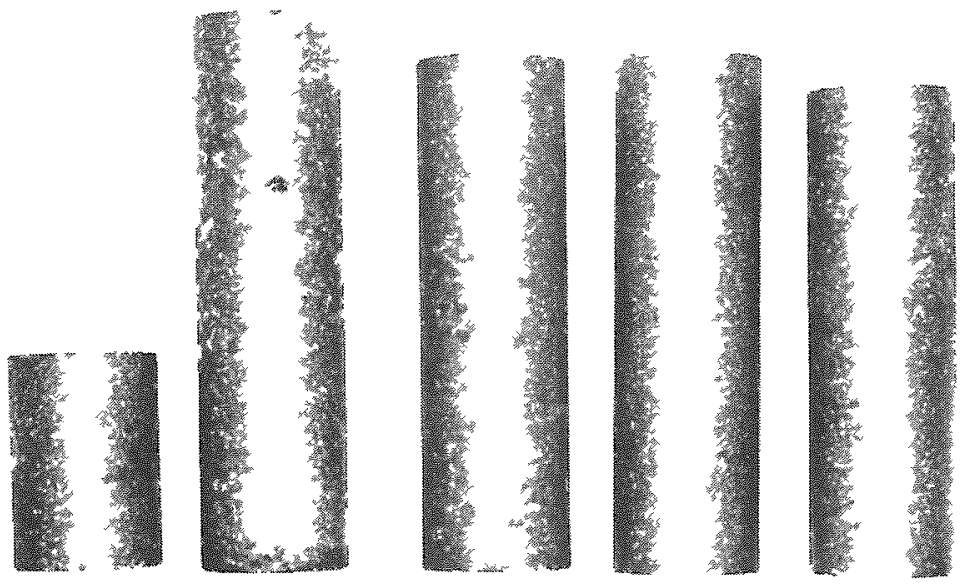

N14511

b. Machned

FIGURE 29. PHOTOGRAPH OF UC SHAPES PRODUCED BY DROP-CASTING TECHNIQUES 

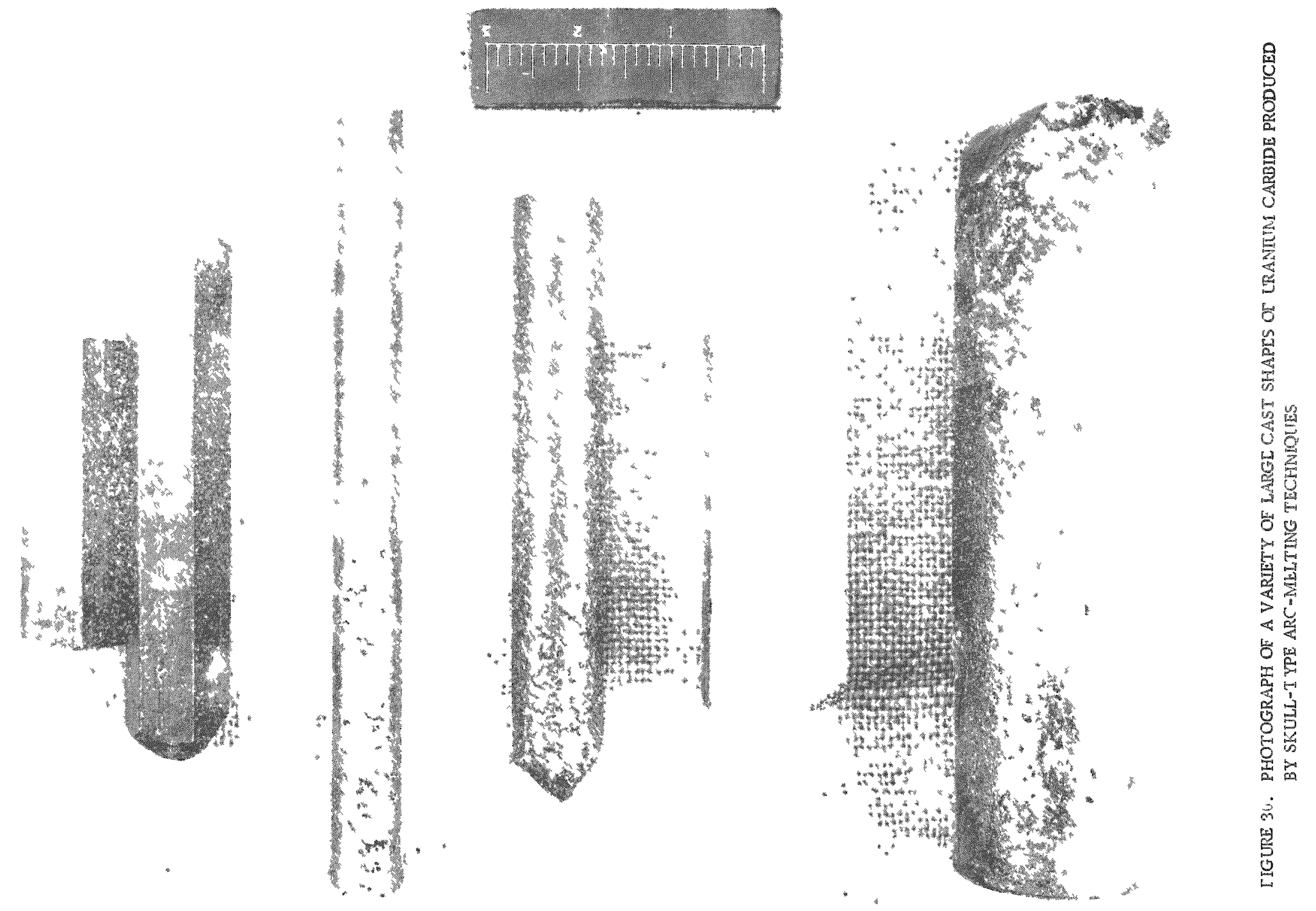
in the carbide skull. It is believed that the se inhomogeneities are related to the character of the charge materials from which the skull is formed. It is expected that control of the character of the charge materials will eliminate the inhomogeneity in the skull.

The skull-type arc-melting and-casting technique is believed to have considerable potential for preparing production quantities of cast UC shapes. Quantity production can be attained by mechanization of the melting operation so as to permit the casting of several fuel slugs simultaneously, and by installing ports to allow recharging of the skull without opening the furnace.

Very little literature on the melting or casting of thorium and plutonium carbides is available. However, it appears that the same techniques that are used for uranium carbides can be used in the preparation of thorium and plutonium carbides.

\section{References}

(1) "Technological Research and Development Report for Month Ending January 15 , $1943^{\prime \prime}$, Chicago University Metallurgical Laboratory, CT-422.

(2) Secrest, A. C., Foster, E. L., and Dickerson, R. F., "Preparation and Properties of Uranium Monocarbide Castings", BMT-1309 (January 2, 1959).

(3) Foster, E。 I., BMI, Unpublished Information.

(4) Turner, D. H. Atomics International, Private Communication.

(5) Gray, R. J., Thurber, W. C., DuBose, C. K. H., "Preparation of Arc-Melted Uranium Carbides", Metal Progress, 74 (1), 65 (July, 1958).

(6) Gray, R. J., Thurber, W. C., DuBose, C. K. H. "Preparation and Metallography of Arc-Melted Uranium Carbides", ORNL-2446 (1958).

(7) "Development and Properties of Uranium Monocarbide Cermets", Armour Research Foundation, AECD-4289 (December 10, 1959).

(8) Kalish, H. S., Bowman, F. E., and Crane, J., "The Development of Uranium Carbides as a Nuclear Fuel", First Quarterly Progress Report, Fuel Cycle Development Program, NYO-2684 (October 19, 1959), pp 19-38.

(9) Finley, J. J., Korchynsky, Mo, and Sarian, S. "Columbium-Clad Uranium Carbide Fuel Element, Quarterly Report No. 2, for August 1-October 31, 1959", ORO222 (November 16, 1959).

(10) Dayton, R. $W_{0}$, and Tipton, $C_{0} R_{0}, J r_{0}$, "Progress Relating to Civilian Applications During August, 1959", BMI-1377 (September 1, 1959).

(11) Dayton, R. Wo, and Tipton, $C_{0} R_{0}, J r_{0}$, "Progress Relating to Civilian Applications During September, 1959", BMI-1381 (October 1, 1959). 


\title{
SOLID-PHASE FABRICATION
}

\author{
J. M. Fackelmann and D. L。 Keller
}

Introduction

Dense forms of uranium carbides may be obtained by several powder-metallurgy techniques. Fabrication methods that have been used are: (1) conventional cold pressing and sintering of uranium carbide powder, (2) hot pressing of uranium carbide powder, (3) hot pressing elemental mixtures of uranium and carbon powders and subsequent reaction at high temperature, and (4) hot extruding elemental powders followed by reaction at high temperature.

Because of its higher density and other desirable characteristics, most of the work. to date has been concerned with UC rather than $U_{2}$. Similar techniques could probably be applied to thorium and plutonium carbides; however, very little data on these materials were fourd in the literature.

\section{Cold Pressing and Sintering}

Uranium carbide powder may be obtained by several methods, as discussed in another section of this report. Since arc melting provides better compositional control of the powder at the present time, most studies have been performed using powder obtained by crushing arc-melted ingots in ball mills or by mortar and pestles. While no economical use is foreseen for fuel elements prepared from arcmelted, crushed, and sintered UC, data obtained on these powders contribute to the understanding of the basic problems involved. Other types of powders for which data have been obtained are those produced by reaction of uranium with methane or propane.

Finely divided uranium-carbon powders are generally pyrophoric and must be protected from rapid reaction with oxygen or moisture, if handled in air. Thus, the material must be crushed either in a dry box under an inert gas or while it is submerged in a fluid such as kerosene or trichloroethylene. Where the hydrocarbons are reacted with uranium to form UC, the product is already in the powder form, and crushing is carried out only if control of particle size is needed.

Binders needed during the cold pressing of brittle powders have also been used to provide protection against atmospheric attack. For example, successful processing in air can be accomplished by soaking fine uranium carbide powders in a 15 w/o camphormethyl alcohol solution. After thorough mixing, excess alcohol is siphoned off, and the balance is removed by evaporation in air, leaving a uniform wax coating on each powder particle. This same coating can serve effectively as a binder during cold pressing and greatly enhances the green strength of the pressed compacts.

In Table 20 the measured density of arc-melted uranium-carbon alloys is compared with the maximum density of mixed uranium and carbon powders having the same carbon content. These data are useful in following the various densification and solid-state reaction processes. 
TABLE 20。 RELATIONSHIP BETWEEN CARBON CONTENT AND DENSITIES OF URANIUM-CARBON COMPOSITIONS

\begin{tabular}{lcc}
\hline $\begin{array}{c}\text { Carbon } \\
\begin{array}{c}\text { Content, } \\
\text { W/o }\end{array}\end{array}$ & $\begin{array}{r}\text { Measured Density of } \\
\text { Arc Melted Material, } \\
\text { g per cm }\end{array}$ & $\begin{array}{r}\text { Maximum Density of } \\
\text { Mixed Components, } \\
\text { g per cm }\end{array}$ \\
\hline 0 & 19.13 & 19.13 \\
1 & 17.57 & 17.69 \\
2 & 16.34 & 16.55 \\
3 & 15.27 & 15.55 \\
4 & 14.33 & 14.46 \\
$4.8(\mathrm{UC})$ & 13.63 & 14.01 \\
5 & 13.42 & 13.86 \\
$9.2\left(\mathrm{UC}_{2}\right)$ & 11.68 & 12.23 \\
\hline
\end{tabular}

Before examining data on sintered carbides it should be pointed out that the carbon content both before and during sintering as well as the impurity level has a profound effect on the sintering characteristics of these particular materials. For example, since the reaction $\mathrm{UC}+1 / 2 \mathrm{O}_{2} \rightarrow \mathrm{U}+\mathrm{CO}$ will proceed rapidly at high sintering temperatures, the presence of oxygen, either in the powder or in the sintering atmosphere, may introduce liquid uranium in the sintering process even in initially hyperstoichiometric materials. Figure 31 shows typical structures of a rim and core, respectively, of the same UC specimen. In the rim sintering has progressed to a highly advanced stage with only isolated closed voids remaining in the grain boundaries. Appreciable grain growth and formation of equiaxed grains can be observed in this zone. Alpha uranium, produced during sintering, is the major grain-boundary constituent. However, in the core, the original angular shape of the UC powder particles is still intact with a minimum of neck growth and densification.

A uranium carbide piece that contains a grain-boundary uranium phase may be unacceptable as a fuel element, especially for use at high temperatures; therefore, the above effects become extremely important in sintered carbides. Carbon analyses of the piece after sintering plus thorough metallographic examinations in addition to density measurements are required for a true evaluation of the sintered compact.

In Figure 32, a relationship is shown between the green density and compacting pressure of three types of uranium-carbon powders: (1) commercial grade, (2) methane product, and (3) crushed arc-melted UC buttons. Naturally, other variables, such as lubricant characteristics, particle size, and geometry, will significantly affect this relationship. The presence of excess uranium in one of the powders $(3.23 \mathrm{w} / 0$ carbon) sharply increased its compactibility as compared with the other powders which were essentially stoichiometric. These data are included to show the general behavior expected during pressing.

Sintering results for powder obtained by crushing arc-melted uranium carbide are summarized in Table 21. The increase in density resulting from free uranium is shown in the table for the compact sintered $10 \mathrm{~min}$ at $1965 \mathrm{C}$ to a density of $11.8 \mathrm{~g} \mathrm{per} \mathrm{cm}^{3}$. On the other hand, times up to 30 min at temperatures ranging from 1840 to $2120 \mathrm{C}$ yielded densities of $10.8 \mathrm{~g}$ per $\mathrm{cm}^{3}$ or lower, this latter series containing considerably less free uranium than the former compact. Examination of Table 21 also shows that use of small particle sizes promotes densification. 


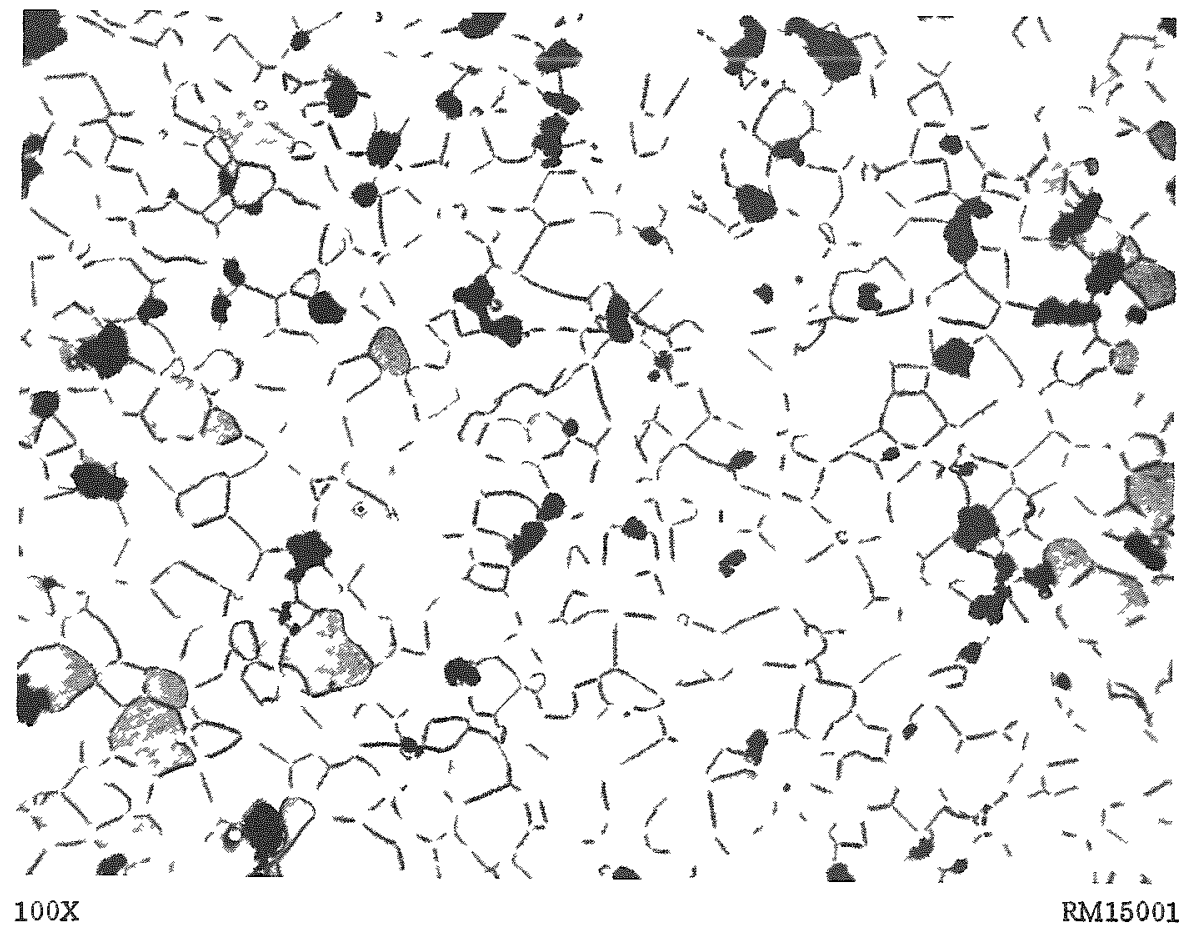

Outer Rum of Compact

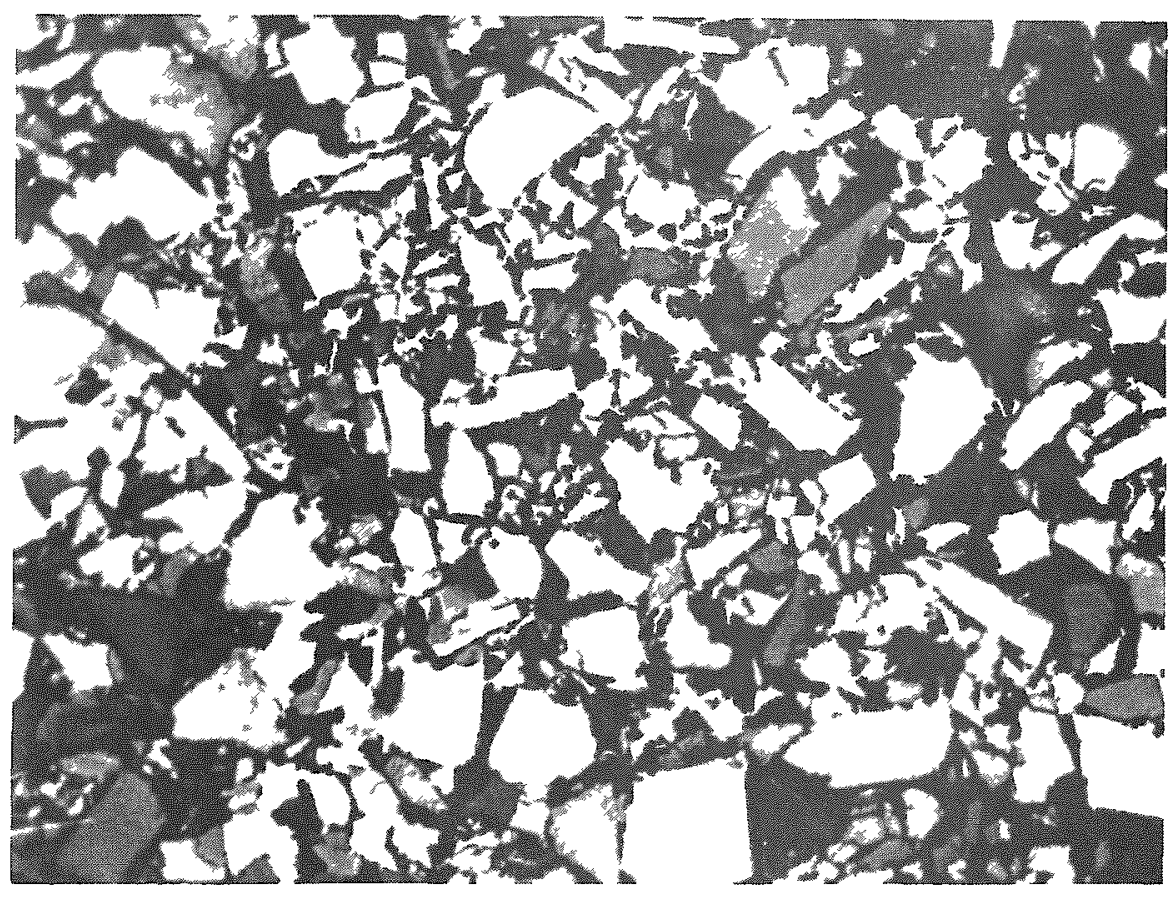

Center of Compact

FIGURE 31. TYPICAL MICROSTRUCTURES OF VACUUM-SINTERCD COMPACT MADE FROM STOICHIOMETRIC UC POWDER 


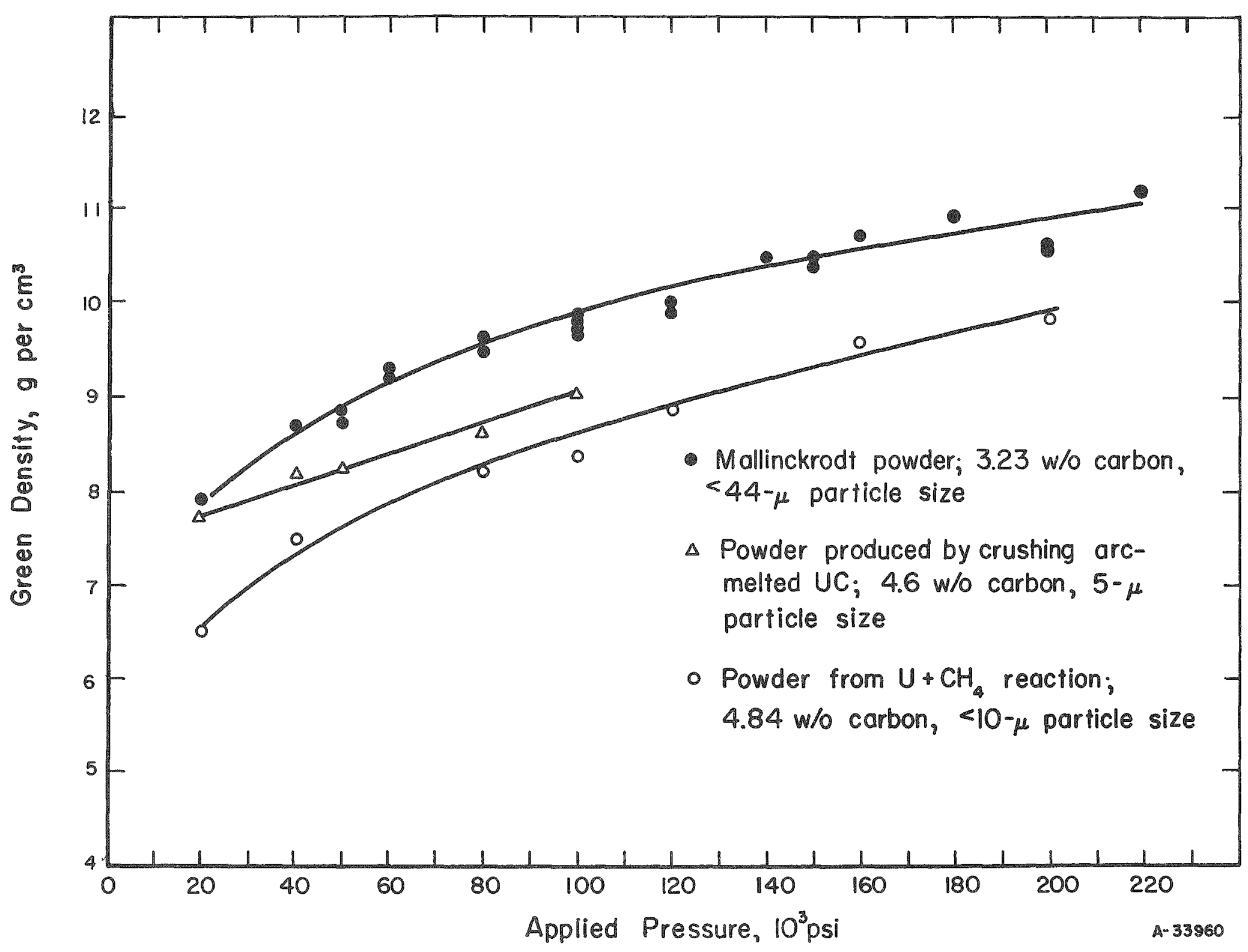

FIGURE 32. RELATIONSHIP BETWEEN GREEN DENSITY AND COMPACTING PRESSURE FOR THREE TYPES OF URANIUM-CARBON POWDERS 
TABLE 21. RESULTS OF VACUUM SINTERING URANIUM-CARBON POWDERS PREPARED FROM ARC-MELTED URANIUM AND GRAPHITE

\begin{tabular}{|c|c|c|c|c|c|c|c|c|c|c|}
\hline \multicolumn{5}{|c|}{ Analysis of Uranium Carbide Powder } & \multirow[b]{2}{*}{$\begin{array}{l}\text { Particle } \\
\text { Size, } \mu\end{array}$} & \multirow{2}{*}{$\begin{array}{c}\text { Green } \\
\text { Compacting } \\
\text { Pressure, psi }\end{array}$} & \multicolumn{2}{|c|}{ Sintering Conditions } & \multirow[b]{2}{*}{$\begin{array}{l}\text { Density, } \\
\text { g per } \mathrm{cm}^{3}\end{array}$} & \multirow[b]{2}{*}{ Referenco } \\
\hline $\begin{array}{c}\text { Total Carbon, } \\
\text { w/o }\end{array}$ & $\begin{array}{c}\text { Free Carbon, } \\
\text { w/o }\end{array}$ & $\begin{array}{l}\text { Oxygen (2), } \\
\text { ppm }\end{array}$ & $\begin{array}{c}\text { Nitrogen }(b) \\
\text { ppm }\end{array}$ & $\begin{array}{c}\text { Hydrogen }(a) \\
\text { ppm }\end{array}$ & & & $\begin{array}{l}\text { Time, } \\
\text { min }\end{array}$ & $\begin{array}{c}\text { Temperature, } \\
C\end{array}$ & & \\
\hline 4.6 & - & $\ldots$ & - & $-\infty$ & $5 \mathrm{avg}$ & 100,000 & 60 & 1815 & 12.87 & (1) \\
\hline 4.96 & -- & -- & - & -- & 6.2 avg & 100,000 & $60-180$ & $1600-1800$ & $0.9-11.8$ & (2) \\
\hline 4.85 & $=-$ & -- & -- & $-\infty$ & 44 & 80,000 & 30 & 2120 & 11.7 & (3) \\
\hline 4.79 & 0.01 & 3040 & $-\infty$ & 58 & 44 & 80,000 & 10 & 1965 & 11.8 & Battelle \\
\hline 4.83 & 0.03 & 790 & 110 & 15 & 44 & 30,000 & $5-30$ & $1840-2120$ & 10.8 & Battelle \\
\hline 4.83 & 0.03 & 790 & 110 & 15 & 44 & 80,000 & 60 & 1900 & 10.1 & Battelie \\
\hline
\end{tabular}

(a) Vacuum-fusion analysis.

(b) Kjeldahi analysis. 
The sintering characteristics of uranium carbide powder produced by the methaneuranium and propane-uranium reactions are shown in Table 22. Densities of $11.0 \mathrm{~g}$ per $\mathrm{cm}^{3}$ are readily attainable at sintering temperatures of $1900 \mathrm{C}$, but $2 \mathrm{hr}$ at $2050 \mathrm{C}$ was required for densities greater than $12.3 \mathrm{~g}$ per $\mathrm{cm}^{3}$ (90 per cent of theoretical) for the compacts using powder produced by the methane reaction. For this high-temperature sintering treatment, it was found that green compacting pressures varying from 40,000 to 200,000 psi produced no significant variation in density. Although no analyses were available after sintering, the analyses given in Table 22 show that high contents of gaseous contaminants were present in the starting powders. The high oxygen contamination, $7000 \mathrm{ppm}$, and the combined carbon content of $4.40 \mathrm{w} / 0(4.84$ minus $0.44 \mathrm{w} / 0)$ indicates that free uranium was prescnt initially. The high nitrogen content may also have influenced sinterability. For powder produced by the propane reaction (Table 22) a density of $11.4 \mathrm{~g}$ per $\mathrm{cm}^{3}$ was obtained by sintering at $1900 \mathrm{C}$, somewhat higher than the density of the methane-produced powder sintered at $1900 \mathrm{C}$. This powder was purer than that produced by the methane reaction, but the combined carbon content of the powder was only $4.36 \mathrm{w} / \mathrm{o}$. No metallographic or chemical analyses of these sintered compacts are available.

Table 23 lists results obtained by sintering uranium carbide powder that was prepared by reacting $\mathrm{UO}_{2}$ and graphite under various conditions. Some of the results $(6)$ include analyses of the sintered compacts. It may be seen that, where contamination was not high, the sintered densities of the se near-stoichiometric UC compacts varied from 8.57 to $10.03 \mathrm{~g}$ per $\mathrm{cm}^{3}$ at sintering temperatures of $1900 \mathrm{C}$ and lower. By contrast, Harwell reports densities up to $12.9 \mathrm{~g}$ per $\mathrm{cm}^{3}$, a value of $12.1 \mathrm{~g}$ per $\mathrm{cm}^{3}$ being obtained after sintering $1 / 2$ hr at $1900 \mathrm{C}$ with considerably coarser powder and lower green compacting pressures. (5) The important point in comparing these results is that the carbon content of the powder used in the latter studies ranged from 4.47 to $4.62 \mathrm{w} / 0$, and no analyses of the sintered compacts are reported. Therefore, it is probable that the high densities reported for this powder, as listed in Table 23, were achieved by liquid-phase sintering. Six-inch-long tubes were also produced at Harwell from this same powder. Wall thiciness was $0.2 \mathrm{in}$, with an outside diameter of 1 in. These tubes could be easily machined after a presintering operation at 1500 C. Density measurements along one such tube ranged from 10.9 to $12.0 \mathrm{~g}$ per $\mathrm{cm}^{3}$, as shown in Table 23 .

Although carbide powder obtained by the $\mathrm{UO}_{2}-\mathrm{graphite}$ reaction contained UC as the major phase, weak $\mathrm{X}$-ray difiraction patterns of $\mathrm{UO}_{2}$ and $\mathrm{UC}_{2}$ were also detected at Union Carbide. (6) Analysis of the powder and sintered compact (10.01 $\mathrm{g}^{\text {per }} \mathrm{cm}^{3}$ ) before and after sintering for 1 hre at $1800 \mathrm{C}$, are shown below:

\begin{tabular}{lrr} 
& \multicolumn{2}{c}{ Analysis, w/o } \\
\cline { 2 - 3 } & Before & After \\
\cline { 2 - 3 } Uranium & 94.22 & 95.21 \\
Total carbon & 4.87 & 4.80 \\
Iron & $0.2 \frac{1}{2}$ & 0.16 \\
Nitrogen(a) & 0.04 & 0.02 \\
Oxygen $^{(a)}$ & 0.63 & 0.04
\end{tabular}

(a) Vacuum-fusion analysis.

Thus, sintering of this compact reduced impurities to the point where a structure estimated to be 99 per cent UC was obtained. (6) Nitrogen contamination appeared to aid sintering considerably. Examples of this effect may be found in Table 23 , which shows that a compact containing 18,200 ppm ritrogen sintered to a density of $13.05 \mathrm{~g} \mathrm{per} \mathrm{cm}^{3}$, 
TABLE 22. VACUUM-SINTERING CHARACTERISTICS OF URANIUM-CARBON POWDERS PREPARED BY REACTING URANIUM WITH METHANE OR PROPANE

\begin{tabular}{|c|c|c|c|c|c|c|c|c|c|c|c|}
\hline \multirow{2}{*}{$\begin{array}{l}\text { Powder } \\
\text { Preparation } \\
\text { Reaction }\end{array}$} & \multicolumn{5}{|c|}{ Analysis of Uranium Carbide Powder } & \multirow[b]{2}{*}{$\begin{array}{l}\text { Particle } \\
\text { Size, } \mu\end{array}$} & \multirow{2}{*}{$\begin{array}{c}\text { Green } \\
\text { Compacting } \\
\text { Pressure, psi }\end{array}$} & \multicolumn{2}{|c|}{ Sintering Conditions } & \multirow[b]{2}{*}{$\begin{array}{l}\text { Density. } \\
{\text { g per } \mathrm{cm}^{3}}^{3}\end{array}$} & \multirow[b]{2}{*}{ Referenc: } \\
\hline & $\begin{array}{c}\text { Total Carbon, } \\
\text { w/o }\end{array}$ & $\begin{array}{c}\text { Free Carbon } \\
\text { w/o }\end{array}$ & $\begin{array}{c}\text { Oxygen } \\
\text { ppm }\end{array}$ & $\begin{array}{c}\text { Nitrogen }^{(a)} \\
\text { ppm }\end{array}$ & $\begin{array}{c}\text { Hydrogen }(a), \\
\text { ppm }\end{array}$ & & & $\begin{array}{l}\text { Time, } \\
\text { min }\end{array}$ & $\begin{array}{c}\text { Temperature, } \\
C\end{array}$ & & \\
\hline Propane & 4.68 & 0.32 & 5600 & 1600 & 46 & 8 avg & 80,000 & 60 & 1900 & 11.4 & Bartelle \\
\hline Methane & 5.98 & 0.16 & 6900 & 950 & 350 & 12 avg & 80,000 & 60 & 1900 & 11.0 & Battelle \\
\hline Methane & 4.84 & 0.44 & 7000 & 7100 & 93 & 10 & $\begin{array}{r}60,000= \\
180,000\end{array}$ & 90 & 2050 & $10.7-11.8$ & (4) \\
\hline Methane & 4.84 & 0.44 & 7000 & 7100 & 93 & 10 & $\begin{array}{l}40,000- \\
200,000\end{array}$ & 120 & 2050 & 12.5 & (4) \\
\hline
\end{tabular}

(a) Vacuum-fusion analysis. Although not accurate for nitrogen, numbers useful in that they represent a minimum. 
TABLE 23. SINTERING CHARACTERTSTICS OF URANIUM-GARBON POWDERS PREPARED BY REACTING UO2 WITH GRAPHITE

\begin{tabular}{|c|c|c|c|c|c|c|c|c|c|c|c|}
\hline \multicolumn{5}{|c|}{ Analysis } & \multirow{4}{*}{$\begin{array}{l}\text { Particle } \\
\text { Size, } \mu\end{array}$} & \multirow{4}{*}{$\begin{array}{c}\text { Green } \\
\text { Compacting } \\
\text { Pressure, } \\
\text { psi }\end{array}$} & \multirow{2}{*}{\multicolumn{2}{|c|}{$\begin{array}{l}\text { Sintering } \\
\text { Conditions } \\
\end{array}$}} & \multirow[b]{4}{*}{ Atuosphere } & \multirow{4}{*}{$\begin{array}{l}\text { Density, } \\
\text { g per con }\end{array}$} & \multirow[b]{4}{*}{ Reference } \\
\hline & & \multirow{2}{*}{\multicolumn{3}{|c|}{ Sintered Compact(a) ppm $^{\text {(a) }}$}} & & & & & & & \\
\hline \multicolumn{2}{|c|}{ Powder, w/o } & & & & & & \multirow{2}{*}{$\begin{array}{l}\text { Time, } \\
\text { min }\end{array}$} & \multirow{2}{*}{$\begin{array}{c}\text { Temperature, } \\
\text { C }\end{array}$} & & & \\
\hline Total Carbon & Free Carbon & $\begin{array}{l}\text { Total } \\
\text { Carbon }\end{array}$ & Oxygen & Nitrogen & & & & & & & \\
\hline $4.47-4.62$ & 0.1 & -- & $\cdots$ & $-\infty$ & $50-100$ & 11,000 & 30 & 1700 & Vacuum & 11.5 & (5) \\
\hline $4.47-4.62$ & 0.1 & $-\infty$ & $-\infty$ & $-\infty$ & $50-100$ & 11,000 & 30 & 1900 & $\begin{array}{l}\text { Vacuum or } \\
\text { argon }\end{array}$ & 12.1 & (5) \\
\hline $4.47-4.62$ & 0.1 & - & $-\infty$ & $-\infty$ & $50-100$ & 22,000 & $\begin{array}{l}\text { Not } \\
\text { specified }\end{array}$ & 1500 & Vacuum & $11.40^{(b)}$ & (5) \\
\hline $4.477-4.62$ & 0.1 & - & - & - & $20-40$ & 22,000 & 60 & 2000 & $\begin{array}{l}\text { Flowing } \\
\text { argon }\end{array}$ & Up to 12.9 & (5) \\
\hline \multirow[t]{2}{*}{$4.47-4.62$} & \multirow[t]{2}{*}{0.1} & \multirow[t]{2}{*}{-} & \multirow[t]{2}{*}{--} & \multirow[t]{2}{*}{-} & \multirow[t]{2}{*}{$20-40$} & \multirow[t]{2}{*}{22,000} & 20 & 1500 & \multirow{2}{*}{$\begin{array}{c}\text { Flowing } \\
\text { argon }\end{array}$} & \multirow[t]{2}{*}{$10.9-12.0$} & \multirow[t]{2}{*}{ (5) } \\
\hline & & & & & & & 30 & 2100 & & & \\
\hline- & -- & 3.96 & 900 & 18,200 & $5 \mathrm{avg}$ & 40,000 & 30 & 1800 & $\begin{array}{c}\text { Flowing } \\
\text { argon }\end{array}$ & 13.05 & (6) \\
\hline$\cdots$ & - & 4.72 & - & 1,000 & $52 \mathrm{vg}$ & 40,000 & 30 & 1800 & $\begin{array}{c}\text { Flowing } \\
\text { argon }\end{array}$ & 8.57 & (6) \\
\hline$-\infty$ & -- & 4.80 & 400 & 200 & 5 avg & 40,000 & 60 & 1800 & $\begin{array}{c}\text { Flowing } \\
\text { argon }\end{array}$ & 10.01 & (6) \\
\hline$-\infty$ & -- & 5.85 & $\infty$ & - & 5 avg & 40,000 & 30 & 1750 & Vacuuno & 8.84 & (6) \\
\hline-- & $-\infty$ & 4.87 & 6300 & 400 & $5 \mathrm{avg}$ & 40,000 & 30 & 1800 & Vacuum & 9.40 & $(6)$ \\
\hline- & -- & 4.75 & $m$ & $-\infty$ & 5 avg & 40,000 & 60 & 1900 & Vacuum & 10.03 & $(6)$ \\
\hline
\end{tabular}

(a) Vacuum-fusion analysis

(b) $10 \mathrm{w} / 0$ iron added to this compact to aid sintering. 
and a compact with 1000 pom nitrogen sintered to a density of $8.57 \mathrm{~g}$ per $\mathrm{cm}^{3}$ after $30 \mathrm{~min}$ at $1800 \mathrm{C} .(6)$

Iron has been added to uranium carbide in an attempt to lower fabrication temperatures by inducing liquid-phase sintering action. (5) A density of $11.40 \mathrm{~g}$ per $\mathrm{cm}^{3}$ was obtained by sintering a uranium carbide $-10 \mathrm{w} / 0$ iron compact at $1500 \mathrm{C}$, as shown in Table 23. Also, Bowman introduced cobalt, copper, iron, and nickel for liquid-phase sintering in his studies of bonding of UC to tantalum. (7) He reports that the liquid phases aided bonding by a wetting action and were removed by vaporization in vacuo at 2000 to $2200 \mathrm{C}$, but no data on the effects on densification, fabrication temperatures, or analyses for the metals after heat treating were given. Preliminary work at Battelle on the effect of chromium as a liquid phase on sintering showed that free uranium formation was eliminated, neck growth between particles was appreciable, and that the 10 volume per cent chromium (5.6 w/o) that had been added could be completely removed by a three-stage sintering treatment of $30 \mathrm{~min}$ at $1030 \mathrm{C}, 50 \mathrm{~min}$ at $1930 \mathrm{C}$, and $50 \mathrm{~min}$ at $2000 \mathrm{C}$. However, little densification occurred. Spectrographic analysis of the resulting compact indicated that less than $0.05 \mathrm{w} / 0$ chromium was present. The uranium carbide powder used for this compact contained $4.89 \mathrm{w} / 0$ total carbon with 1 es $\mathrm{s}$ than $0.01 \mathrm{w} / 0$ free carbon.

The sintering characteristics of $\mathrm{UC}_{2}$ have received some attention. (1) An average density of $10.7 \mathrm{~g}$ per $\mathrm{cm}^{3}$ (theoretical density is $11.7 \mathrm{~g}$ per $\mathrm{cm}^{3}$ ) was observed for compacts prepared from $5-\mu$ powder that had been obtained by ball milling an arc-melted uranium -8.6 w/o total carbon alloy containing $1.2 \mathrm{w} / 0$ of impurities. These compacts were sintered $1-1 / 2$ hr at $1840 \mathrm{C}$ after cold pressing at 100,000 psi.

No data were available on the sintering characteristics of thorium or plutonium carbides. The monocarbide of thorium, being quite similar to UC, probably behaves in a fashion sinilar to UC in sintering, although sintering temperatures may be higher due to its higher melting point. Considering sintering temperatures to be proportional to melting point, the order of increasing sintering temperatures would probably be plutonium carbides, uranium carbides, and thorium carbides.

\section{Extrusion}

Mixtures of uranium and graphite powders, containing up to $5 \mathrm{w} / 0$ carbon, have been successfully extruded at $800 \mathrm{C}$ and subsequently reacted at $1100 \mathrm{C}$ to form uranium carbide. Densities of 96.2 and 85.7 per cent of theoretical were obtained for uranium-4 and $-5 \mathrm{w} / \mathrm{o}$ carbon mixes, respectively. (5) Mixtures of uranium powder, minus 300mesh graphite, and parafin were cold pressed at 22,000 to 55,000 psi, and then hot compacted in the extrusion die to about half of the original length, after the extruding temperature of $800 \mathrm{C}$ was reached. The piece was extruded at pressures of 4,000 to $12,000 \mathrm{psi}$. using a 12:1 reduction in area, to produce a rod 0.318 in. in diameter. An impure argon atmosphere was used with the wax binder, providing protection from oxidation. (5) The densities after extrusion of the above 4 and $5 \mathrm{w} / 0$ carbon pieces were 14.04 and $13.50 \mathrm{~g}$ per $\mathrm{cm}^{3}$, respectively, the major constituents of the structure being uranium and graphite. The rods were then reacted at $1100 \mathrm{C}$ (no times given) to form uranium, $\mathrm{UC}$, and $\mathrm{UC}_{2}$. Although no analyses were given to show that the elements had completely reacted, it was staced that uranium-graphite compacts that were heat treated in vacuum $21 \mathrm{hr}$ at $1100 \mathrm{C}$ after hot pressing at $750 \mathrm{C}$ contained no free graphite by $\mathrm{X}-\mathrm{xay}$ and 
metallographic analyses. After reacting at $1100 \mathrm{C}$, the rod densities were 12.73 and $11.91 \mathrm{~g} \mathrm{per} \mathrm{cm}^{3}$, respectively. The reductions in density are undoubtedly caused by carbon monoxide produced by reaction of the carbon and oxygen present in the powder mixtures.

The surface quality of the $5 \mathrm{w} / 0$ carbon rod was described as good, although severe die wear was experienced. A mirror finish was obtained on the 4 w/o carbon rod, and no appreciable die wear occurred in extrusion of this rod when graphite inserts were used.

\section{Hot Pressing}

Uranium carbide pieces have been produced by hot pressing both uranium-carbide powders, and mixed uranium-graphite powders followed by a reaction heat treatment.

Using the latter method, densities consistently greater than 90 per cent of theoretical were obtained for products having carbon contents of $4,4.8$ and $5 \mathrm{w} / 0$, when studies were performed on a small scale; however, lower densities were obtained in larger scale experiments. (5) Results of these experiments are shown in Table 24. Stellite dies were used in preparing these compacts, and it was found that temperatures up to $750 \mathrm{C}$ at pressures of 33,000 psi could be used without excessive die attack. Although the mixing techniques used in obtaining the results in Table 24 were not given, colloidal graphite was mixed with uranium powdex. The uranium powder was added to a very fine colloidal graphite in an alcohol suspension. The amount of carbon added to the uranium was varied by adjusting the volume of the suspension, the carbon content of which was estimated by both density measurements and drying. The dried mixture was then pressed. Thorough drying was found to be essential, since some powders that were not dried completely exploded during hot pressing. No metallographic or chemical analyses were reported to give an indication of the completeness of carbide formation.

Dubisson, et al. ${ }^{(8)}$ hot pressed graphite-uranium mixtures to densities that were consistently 98 per cent of theoretical. The results for various carbon contents up to about $4.6 \mathrm{w} / \mathrm{o}$ are plotted in Figure 33. Pressures of 2800 psi were applied for $3 \mathrm{hr}$ at $900 \mathrm{C}$ in a double-action graphite die. Special mixing and powder-preparation techniques were used. A zinc coating applied to the high-purity uranium powder facilitated handling in air without oxidation and activated the surface. No reacting treatment was necessary, since reaction occurred simultaneously with hot pressing at the pressure temperature of 900 C. Analyses fox free carbon confirmed metallographic analyses in determining that practically all the carbon had reacted. A free carbon content of $0.045 \mathrm{w} / \mathrm{o}$ was typical, and no $\mathrm{UC}_{2}$ was detected by X-ray analyses. Structures contained only UC and uranium. No data were reported for specimens having carbon contents of $4.8 \mathrm{w} / \mathrm{o}$ or greater.

Hot pressing of uranium carbide powders has also been studied by Union Carbide. (4) Powder produced commercially by Mallinckrodt which contained $3.23 \mathrm{w} / 0$ total carbon was mixed with $1.65 \mathrm{w} / 0$ graphite and was compacted for 30 min at $1600 \mathrm{C}$ in a tungsten die in a partial vacuum. A density of $12.50 \mathrm{~g} \mathrm{per} \mathrm{cm}^{3}(91.8$ per cent of theoretical) was measured on this compact. The microstructure of this specimen consisted of UC grains with a small amount of $\mathrm{UC}_{2}$ in the grain boundaries. 


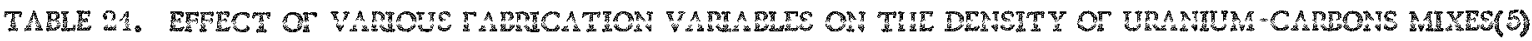

\begin{tabular}{|c|c|c|c|c|c|c|}
\hline \multirow[b]{2}{*}{ Type of Carbon } & \multirow{2}{*}{$\begin{array}{c}\text { Carbon } \\
\text { Content, } \\
\text { W/o }\end{array}$} & \multicolumn{2}{|c|}{$\begin{array}{l}\text { Hot-Pressing } \\
\text { Conditions } \\
\end{array}$} & \multirow{2}{*}{$\begin{array}{c}\text { Reacring } \\
\text { Temperature, } \\
\text { C }\end{array}$} & \multirow[b]{2}{*}{$\begin{array}{l}\text { Densicy. } \\
8 \text { per } \mathrm{cm}^{3}\end{array}$} & \multirow[b]{2}{*}{ Comments } \\
\hline & & $\begin{array}{c}\text { Temperature, } \\
\text { C }\end{array}$ & $\begin{array}{c}\text { Pressure, } \\
\text { psi }\end{array}$ & & & \\
\hline Coarse BDH graphite & 4 & 750 & 33,000 & - & 14.14 & Small scale \\
\hline Coarse BDH graphite & 5 & 750 & 33,000 & $=$ & 13.77 & Small scale \\
\hline Coarse BDH graphite & 4 & 750 & 33,000 & 1100 & 13.00 & Small scale \\
\hline Coarse $\mathrm{BDH}$ graphite & 5 & 750 & 33,000 & 1100 & 12.20 & Small scale \\
\hline Carbon black & 4 & 670 & 33,000 & - & 12.20 & Larger scale \\
\hline Carbon black & 4.8 & 670 & 33,000 & - & 11.20 & Larger scale \\
\hline Carbon black & 4 & 670 & 33,000 & 1000 & 12.27 & Larger scale \\
\hline Carbon black & 4.8 & 670 & 33,000 & 1000 & 11.32 & Larger scale \\
\hline Superfine graphite & 4 & 670 & 33,000 & -- & 13.7 & Larger scale \\
\hline Superfine graphite & 4.8 & 670 & 33,000 & - & 12.8 & Larger scale \\
\hline Superfine graphite & 5.0 & 670 & 33,000 & - & 12.0 & Larger scale \\
\hline
\end{tabular}

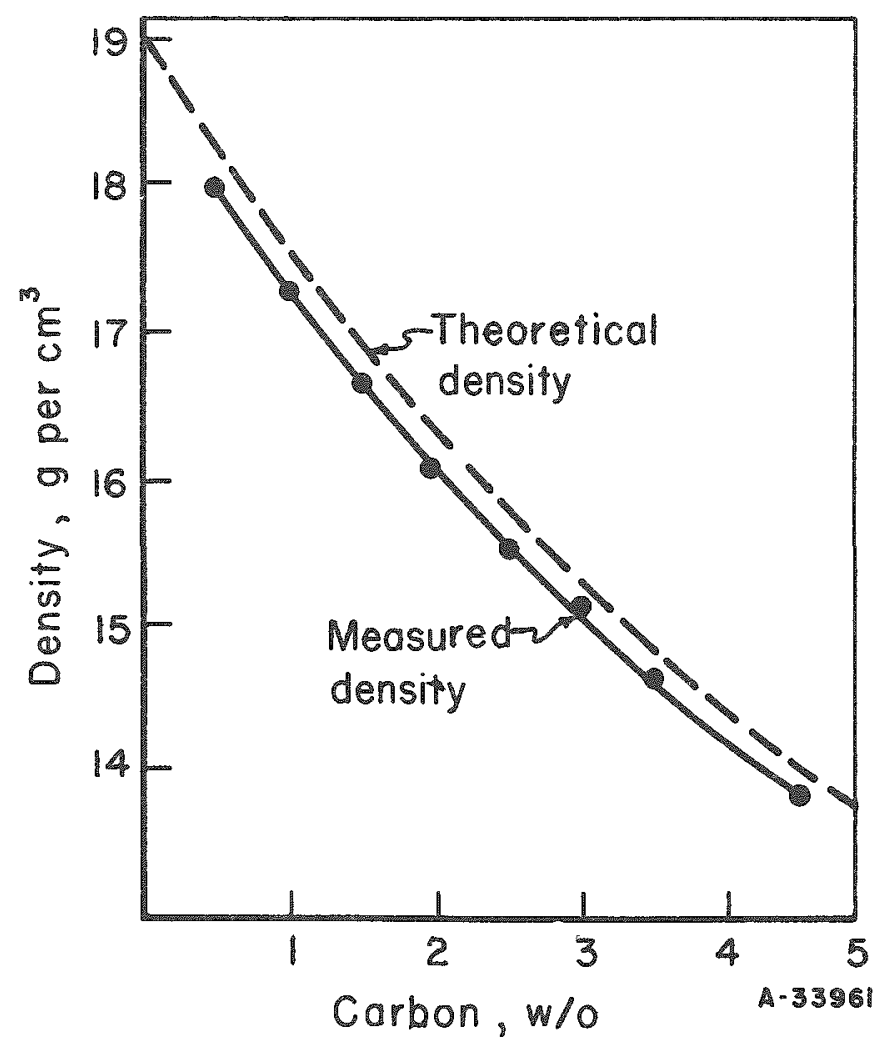

FIGURE 33. DENSITY OF URANIUM-GRAPHITE MIXTURES HOT PRESSED AT $900 \mathrm{C}^{(8)}$ 


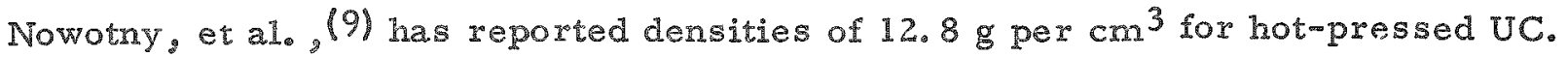
Although pressing conditions were not specified, the powder used was prepared by the $\mathrm{UO}_{2}$-graphite reaction and contained $4.84 \mathrm{w} / 0$ total carbon and $0.16 \mathrm{w} / 0$ free carbon. $\mathrm{X}-\mathrm{ray}$ analyses of the starting powder indicated that UC was the major phase with a small amount of $\mathrm{UC}_{2}$ present.

\section{Summary}

Preliminary studies indicate that temperatures in excess of $1900 \mathrm{C}$ will be required to fabricate high-density stoichiometric UC pieces from powder by cold pressing and sintering techniques. However, the fabrication temperature may be significantly lowered. by resorting to a liquid-phase sintering process. Preliminary indications are that the elements used to provide liquid-phase sintering can be removed by vaporization during sintering. While the use of liquid-phase uranium substantially lowers fabrication temperatures, consideration must be given to its effect upon irradiation resistance and cladding compatibility. Fine particle sizes, in the $5-\mu$ range, enhance sintering. Compacting pressures in excess of 50,000 psi appear to have little effect on densification of the sintered product.

Extruding or hot pressing mixtures of uranium and graphite powder, and simultaneously or subsequently reacting them to form the carbide appears very attractive. In these processes, high densities can be achieved with maximum temperatures of only about $1100 \mathrm{C}$. The major problems encountered in extrusion appear to be die wear and control of surface quality because of the formation of small amounts of the abrasive UC or $\mathrm{UC}_{2}$ during billet heating. Although the atmosphere in hot pressing may be more closely controlled than in extrusion, the capacity to produce large pieces is reduced.

While considerable work has been done on solid-phase reactions to form uranium carbide fuel pellets, much additional research is needed to establish a commercial process. Two processes appear to have considerable merit for preparation of high-density bodies of UC, if free uranium is to be eliminated. These are hot pressing or extrusion of mixed powders of uranium and carbon followed by reaction at elevated temperature, and liquid-phase sintering of uranium carbide powders containing additives such as chromium, iron, or nickel. The latter process may become more attractive, if an economical process should be developed for preparation of UC powders.

\section{References}

(1) Tripler, A. $B_{0}, J_{1}$, Snyder, $M_{0} J_{0}$, and Duckworth, W. $H_{0}$, "Further Studies of Sintered Refractory Uranium Compound", BMI-1313 (January 27, 1959).

(2) Tripler, A. B., Jro, Snyder, M. J., and Duckworth, W. H. "A Study of the Effects of Fabrication Conditions on Some Properties of Sintered Uranium Monocarbide", BMI-1383 (October 2, 1959).

(3) Rough, F. A., and Chubb, W., "Progress on the Development of Uranium CarbideType Fuels", BMI-1370 (August 21, 1959). 
(4) Finley, I. I. Karchymaly, $M$, and Sarian, $S_{z}$, "Columbium Clad Uranium Carbide Fuel Element, Quarterly Report No.2 for August 1-October 31, 1959", ORO-222 (November 16, 1959).

(5) Barnes, E., Munro, W., Thackery, R. W., Williams, J., and Murray, P., "The Preparation, Fabrication, and Properties of Uranium Carbide and Uranium-Uranium Carbide Cermets", Metallurgy and Fuels, Edited by H. M. Finniston and J.P. Howe, Pergamon Press (1956), pp 435-47.

(6) Taylor, K. M., Lenie, C. A., and Smudski, P. A., "Synthesis and Fabrication of Refractory Uranium Compounds, Quarterly Report No. I for May 13 to August 31, 1959, ORO-212 (1959).

(7) Bowman, M. G. "Bonding Uranium Carbide to Tantalum", AECU-4303 (May, 1959).

(8) Dubuisson, J., Houyvet, A., LeBoulbin, E., Lucas, R., and Moranville, C., "The Preparation of Uranium Uranium Carbide Cermets and Stoichiometric Monocarbide by Sintering Under Stress", Proceedings of the Second United Nations International Conference on the Peaceful Uses of Atomic Energy, Geneva (1958), Vol 6, A/Conf. 15/P/1162, pp 551-60.

(9) Nowotny, H., Kieffer, R., and Benesovsky, F。, "Preparation of UC and Its Relation to the Carbides of Refractory Transition Metals", Rev。 mét., 55, 453-58 (May, 1958).

\title{
STORAGE AND ILANDLING
}

\author{
W. M。 Phillips
}

Bulk Uranium Carbides

Of the three corrosion media encountered in normal storage and processing (nitrogen, oxygen, and water), water is the most corrosive and damaging to carbide fuels. Saturated water vapor at $40 \mathrm{C}$ will cause complete disintegration of a $10-\mathrm{g}(3 / 8-\mathrm{in}$. diameter by 1/2-in.-long cylinder) sample of UC in $24 \mathrm{hr}$. (1) Because of this type of attack by water vapor, specimens to be kept for long periods of time must be stored in desiccators. Although the weight change observed during a 2 -month storage period in a desiccato $x$ is insignificant(2), transverse rupture strengths of machined specimens have been observed to decrease slightly as storage time is increased over a period of 2 to 3 months. This would indicate that sufficient moisture was adsorbed on the specimens during handling or machining to produce a surface attack or microcracking of the specimens during storage, although the amount of attack is not measurable in terms of a weight change.

As indicated in the section on compatibility and corrosion, it is believed that $U \mathrm{C}_{2}$ is more readily attacked by moist air than is $U C_{2}$ and that the presence of $\mathrm{UC}_{2}$ as a second phase in UC may thus be undesirable. 
Machine grinding of cast uranium carbide has been found to be satisfactory. Specimens ground on a silicon carbide wheel produced some loading of the wheel, accompanied by spalling of the specimen. This spalling was eliminated by the use of a resinmbonded diamond wheel. During the grinding operation, the specimen is held between pressure pads. Specimens have been ground to diameters as small as $3 / 16$ in. with no difficulty. (3)

Three cutting fluids have been used in conjunction with the resin-bonded diamond wheel: kerosene, water-soluble oil, and cutting oil. Kerosene is satisfactory for use with a small cutoff wheel, since no reaction has been observed between UC and kerosene. However, if a heavy cut is taken overheating occurs, and kerosene vapor is produced, resulting in a fire hazard. The water-soluble oil is satisfactory for use with sound specimens, provided the cutting fluid is completely removed prior to storage. This fluid was used to grind a 2 -in.-diameter specimen which contained fine radial cracks. After grinding, the specimen began to disintegrate. This continued for a period of more than a week, until the specimen was reduced to small pieces. This is the result of the waterbase cutting fluid entering the cracks. Thus, at the present time, all grinding is done using undiluted cutting oil with no resultant decreases in surface quality or in diameter tolerances of the order of $\pm 0,001 \mathrm{in}$. (1)

Holes $1 / 8$ in. in diameter have been drilled through the center line of $3 / 8-$ in. diameter cast specimens 1 in. long. Ultrasonic drilling techniques involving a steel tool and a silicon carbide abrasive have been found satisfactory.

As indicated in the section on compatibility, there are numerous materials which will wet UC and which might therefore be used as a protective coating. For example, nickel has been vapor deposited on UC for this purpose. Water-corrosion tests of the coated specimen indicated that the corrosion rate was reduced by the coating. (4)

\section{Uranium Carbide Powders}

Extreme care is required in storing and handling fine uranium carbide powders because of the possibility of fires or explosions. Powders, of course, can be protected during handling by coatings or by binders and lubricants, as discussed briefly in the section on solid-state fabrication processes.

\section{Thorium and Plutonium Carbides}

Thorium carbide, even in bulk form, is attacked by dry air at room temperature. It must be stored in an inert atmosphere.

No information is available on the handling characteristics of the plutonium carbides. 


\section{References}

(1) Foster, E. L., BMI, Unpublished Information.

(2) Price, R. B., Stahl, D., Stang, J. H., and Simons, E. M., "Irradiation-Capsule Study of Uranium Monocarbide", BMI-1425 (March 2, 1960).

(3) Secrest, A. C., Foster, E. L, and Dickerson, R. F。, "Preparation and Properties of Uranium Monocarbide Castings", BMI-1309 (January 2, 1959)。

(4) Boettcher, A., and Schneider, G. "Some Properties of Uranium Monocarbide", Proceedings of the Second United Nations Conference on the Peaceful Uses of Atomic Energy, Geneva (1958), Vo1 6, A/Conf. 15/P/964, pp 561-63. 
EFFECTS OF IRRADIATION UPON URANIUM CARBIDE

\author{
F.A. Rough
}

Introduction

Relatively few data are available on the effects of irradiation upon bulk uranium carbides or upon uranium carbides in any form. The objective of this review is to present and evaluate the results of irradiation upon bulk uranium carbides. Because of possible effects of impurities and the possible effects of reactions between the dispersed phase and the matrix, the results of irradiations of dispersions and cermets containing uranium carbide contribute little to the understanding of the effects of irradiation upon bulk carbides and thus are not included in the present review.

The principal source of information on the effects of irradiation upon uranium carbides is an irradiation program being conducted at Battelle in cooperation with Atomics International. This program involves the irradiation of uranium carbide specimens having carbon compositions in the vicinity of stoichiometric uranium monocarbide, but ranging from 4.6 to $5.3 \mathrm{w} / 0$ carbon. The specimens were prepared by inert-electrode arc melting of biscuit uxanium and spectrographically pure carbon and then casting the carbide into graphite molds by the technique described in the section on melting and casting. The procedures of preparation, the properties of the carbide, and the irradiation procedures and results obtained in this program have been described in a series of reports and papers.(1-6) The program is largely completed, but one capsule intended to achieve a burnup of 2.2 a/0 uranium (20,000 MWD/T of uranium) remains to be examined. A description of the irradiation parameters of the capsules which have been examined appears as Table 25.

\title{
Observed Effects of Irradiation on Uranium Carbide
}

Cast Uranium Carbide

Specimens of as cast uranium monocarbide, machined to 3/8-in,-diameter cylinders about $2 \mathrm{in.}$. in length, have been irradiated in NaK as shown in Table 25 to burnups of about 1.7 a/o of the uranium. The temperatures during irradiation, as determined by thermocouples, varied; average surface temperatures ranged from 540 to $915 \mathrm{~F}$, while average center-line temperatures ranged from 880 to $1450 \mathrm{~F}$. The maximum surface and center-line temperatures were generally about $200 \mathrm{E}$ higher. The density changes observed were modest, being in the range of -0.6 to -2.5 per cent, regardless of burnup. Cracking occurred probably as a result of themal stresses, but disintegration attributable to accumulation of fission products was absent, as illustrated by Figure 34 . The amount of cracking increased somewhat with increased ixradiation. The surfaces were damaged somewhat, apparently by orygen pickup from the NaK. The quantity of fission gases released into the capsule, as determined by collecting and measuring the krypton85 contained in the capsule after irradiation, was small. Postirradiation heating for 1 week at $1800 \mathrm{~F}$ and $8 \mathrm{hr}$ at $2000 \mathrm{~F}$ released very small amounts of the contained fission gases. $(2-7)$ 
TABLE 25. IRRADLATION DATA ON UC SPECIMENS

\begin{tabular}{|c|c|c|c|c|c|c|c|c|c|c|}
\hline & \multicolumn{2}{|c|}{ Capsule A } & \multicolumn{2}{|c|}{ Capsule $\mathbb{B}$} & \multicolumn{2}{|c|}{ Capsule C } & \multicolumn{2}{|c|}{ Capsule D } & \multicolumn{2}{|c|}{ Capsule E } \\
\hline & $\begin{array}{c}\text { Top } \\
\text { Specimen }\end{array}$ & $\begin{array}{c}\text { Bottom } \\
\text { Specimen }\end{array}$ & $\begin{array}{c}\text { Top } \\
\text { specimen }\end{array}$ & $\begin{array}{c}\text { Bottom } \\
\text { Specimen }\end{array}$ & $\begin{array}{c}\text { Top } \\
\text { specimen }\end{array}$ & $\begin{array}{l}\text { Bottom } \\
\text { specimen }\end{array}$ & $\begin{array}{c}\text { Top } \\
\text { specimen }\end{array}$ & $\begin{array}{l}\text { Botion } \\
\text { Specimen }\end{array}$ & $\begin{array}{c}\text { Top } \\
\text { Specimen }\end{array}$ & $\begin{array}{l}\text { Botrom } \\
\text { Specimer }\end{array}$ \\
\hline Carbon Content, $w / 0$ & 5.2 & 5.2 & 5.3 & 5.1 & 5.0 & 5.0 & 4.6 & 4.7 & 4.8 & 4.6 \\
\hline Diameter Change, per cenc & 0.4 & 0.3 & 0.9 & 0.9 & $-\infty$ & 0.8 & 0.8 & 1.2 & 0.5 & 0.5 \\
\hline Density (a) Change, per cent & $0.7-0.9$ & 2.5 & $0.6-2.0$ & 2.5 & 1.8 & 1.8 & 2.4 & 1.6 & 1.2 & 1.6 \\
\hline \multicolumn{11}{|l|}{ Average Temperature, $F$} \\
\hline Surface & 770 & 540 & 915 & 700 & 765 & 623 & 882 & 772 & 815 & 600 \\
\hline Core & 1,300 & 880 & 1,375 & 1.060 & 1,178 & 1,086 & 1,326 & 1,248 & 1,450 & 950 \\
\hline 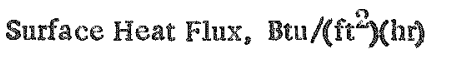 & 680,000 & 850,000 & 880,000 & 940,000 & 750,000 & 700,000 & 900,000 & 710,000 & 600,000 & -- \\
\hline \multicolumn{11}{|c|}{ Fission-Gas Release, $\mathrm{cm}^{3}$ of krypton-85 } \\
\hline Estimated Total Produced & \multicolumn{2}{|c|}{$5.9 \times 10^{-2}$} & \multicolumn{2}{|c|}{$20.9 \times 10^{-2}$} & \multicolumn{2}{|c|}{$\ldots$} & \multicolumn{2}{|c|}{$20.4 \times 10^{-2}$} & \multicolumn{2}{|c|}{$21.9 \times 10^{-2}$} \\
\hline Estimated Released by Recoil & \multicolumn{2}{|c|}{$2.5 \times 10^{-5}$} & \multirow{2}{*}{\multicolumn{2}{|c|}{$8.8 \times 10^{-5}$}} & \multicolumn{2}{|c|}{-} & \multicolumn{2}{|c|}{$8.7 \times 10^{-5}$} & \multicolumn{2}{|c|}{$9.4 \times 10^{-5}$} \\
\hline Measured Release & \multicolumn{2}{|c|}{$2.4 \times 10^{-5}$} & & & \multicolumn{2}{|c|}{ (b) } & \multicolumn{2}{|c|}{$8.2 \times 10^{-5}$} & \multicolumn{2}{|c|}{$8.4 \times 10^{-5}$} \\
\hline Burnup, a/o of the uranium & 0.16 & 0.20 & 0.6 & 0.8 & 1.7 & 1.7 & 0.9 & 0.9 & - & -- \\
\hline Bumup, MWD/T of uranium & \multicolumn{2}{|c|}{1,000} & \multicolumn{2}{|c|}{5,000} & \multicolumn{2}{|c|}{10,000} & \multicolumn{2}{|c|}{5,000} & \multicolumn{2}{|c|}{5,000} \\
\hline
\end{tabular}

(a) In every case, density measurements were made on the largest fractions of the original specimens.

(b) Fission-gas sample was lost, apparenty by leakage from capsule. 

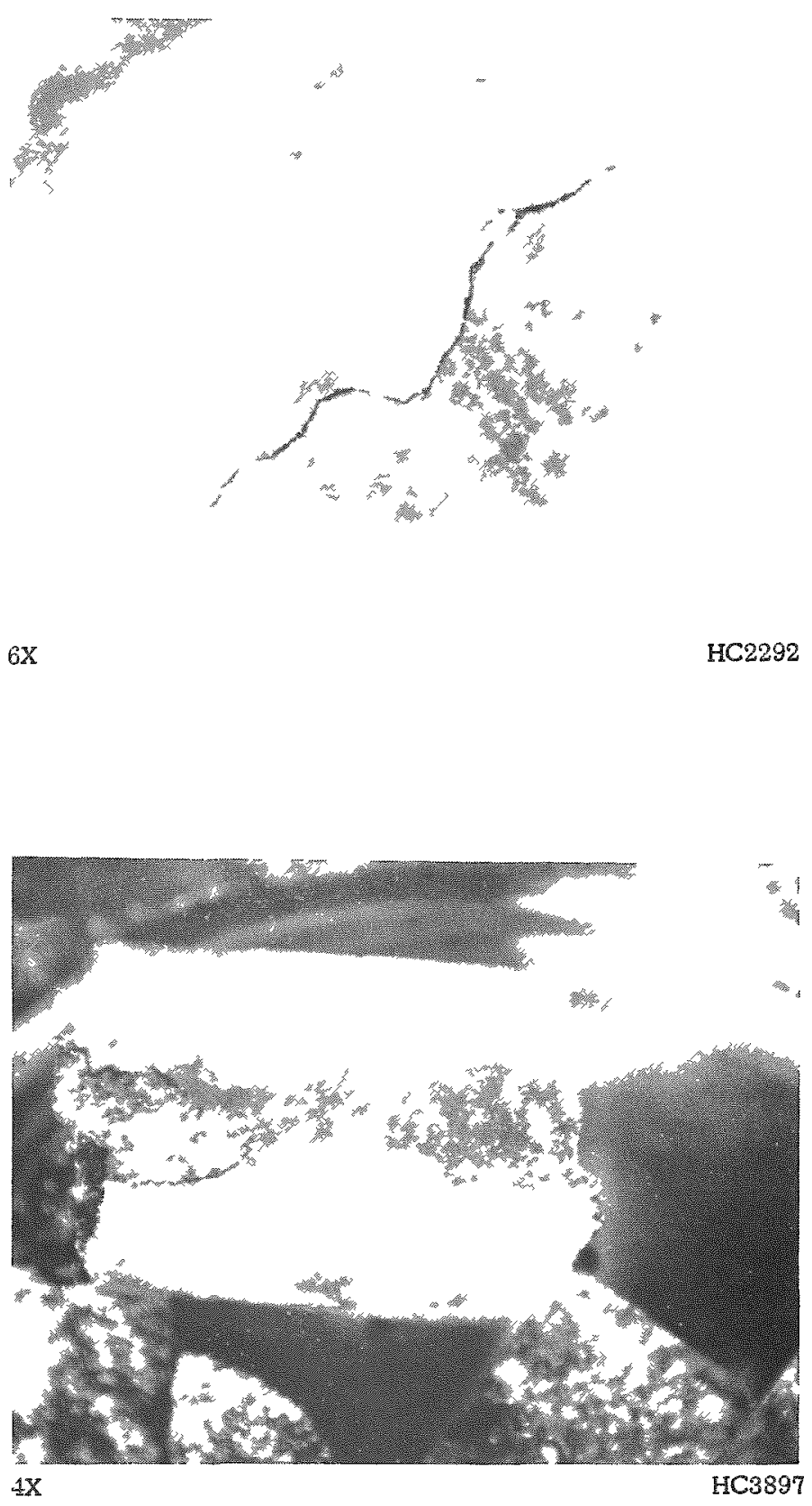

FIGURE 34. APPEARANCE OF UC SPECIAENS AITER IRRADIATIONS TO BURNUPS OR 0.6 a $\%$ OF THE URANIUM AT 1375 E (TOP) AND TO 1.7 a/O OF THE URANUM AT 1086 F (BOTTOM) 
Based upon room-temperature rupture strengris, which vary cunsiueialiy fü UC, one might expect thermal gradients of 50 to 200 F to cause cracking (7) Although the mechanical-property data needed to evaluate cracking at high temperatures are not available, there is good reason to believe that both the radial and transverse cracking which has been observed in uranium monocarbide is the result of thermal stresses. In some cases, microcracks have been observed in areas at or near the center of specimens as shown in Figure 35. The cause of this type of cracking is uncertain. One might imagine that stress relief due to irradiation annealing could occur at temperature. If so, upon cooling, the center areas of the specimens would be placed in tension, perhaps causing cracking at room temperature. (7)

It is believed that the surface damage shown in Figure. 36 was caused by reaction of small amounts of oxygen in the NaI-filled capsule with the UC during irradiation. The damage shown is similar in many respects to that produced by exposures of UC to moist air.

Another type of damage manifested by a porous appearance was observed near a thermocouple located in the center of a UC specimen. This location experienced a transient temperature of $1830 \mathrm{~F}$. (3) It is possible that this effect was caused by the action of $\mathrm{NaK}$ or by local overheating caused by the formation of NaK vapor. Aithough the capsule was designed to avoid vaporization of the $\mathrm{NaK}$, local vaporization or boiling may have occurred in the confined space around the the rmocouple.

The density decreases shown in Table 25 are about the same regardless of burnup. Thus, the density changes produced in the lattice of UC by accumulation of fission products tend to be obscured by the effects of internal cracks, surface damage, and experimental difficulties. The true density change is probably less than the approximately 1 per cent per a/o uranium burnup observed for the specimens in Capsule C (Table 25) which received burnups of 1.7 a/0 of the uranium.

Calculations have been made of the density changes one might expect as a result of the accumulation of fission products in the lattice of UC using various assumptions somewhat similar to calculations that have been made for other alloys. (8) The volume changes calculated for 1 a/o uranium burnup range from +1.0 to +1.6 per cent. The former value refers to high-temperature irradiations, where the fission products are assumed to diffuse to substitutional positions vacated by fissioning uranium atoms. In the latter case, the calculations were made for low temperatures where the fission products were assumed to be immobile, falling equally in substitutional or interstitial positions depending upon the frequency of occurrence of the se positions in the lattice.

The principal microstructural change that has been observed in irradiated uranium monocarbide is the disappearance of the $\mathrm{UC}_{2}$ platelets, as shown in Figure 35 . In the top specimen in Capsule C (Table 25 ), the $\mathrm{UC}_{2}$ platelets disappeared from the entire cross section. In the bottom specimen in Capsule $C$ the platelets were completely gone at the center and showed signs of beginning to disappear at the specimen surface. These effects observed at burnups of 0.8 and 1.7 a/0 of the uranium are illustrated in Figures 35 and 37. However, this change in microstructure produced no other manifestations of damage. The appearance and over-all effects of irradiation on specimens containing $4.6 \mathrm{w} / 0$ to $5.2 \mathrm{w} / 0$ carbon at burnups of about 0.2 to 1.7 a $/ 0$ of the uranium were the same, as can be seen in photomicrographs and in Table 25. It is possible that the UC 2 platelets 


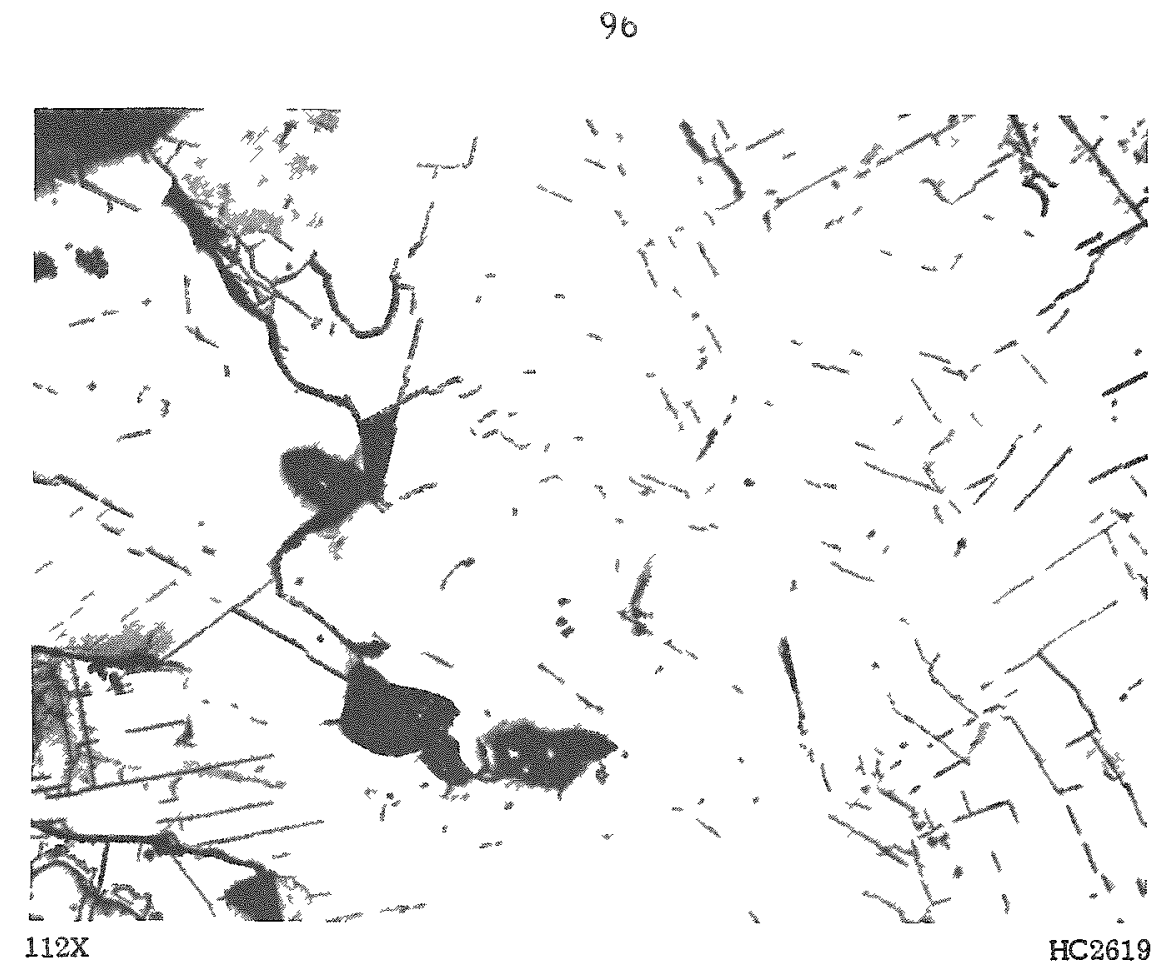

Center Secuon

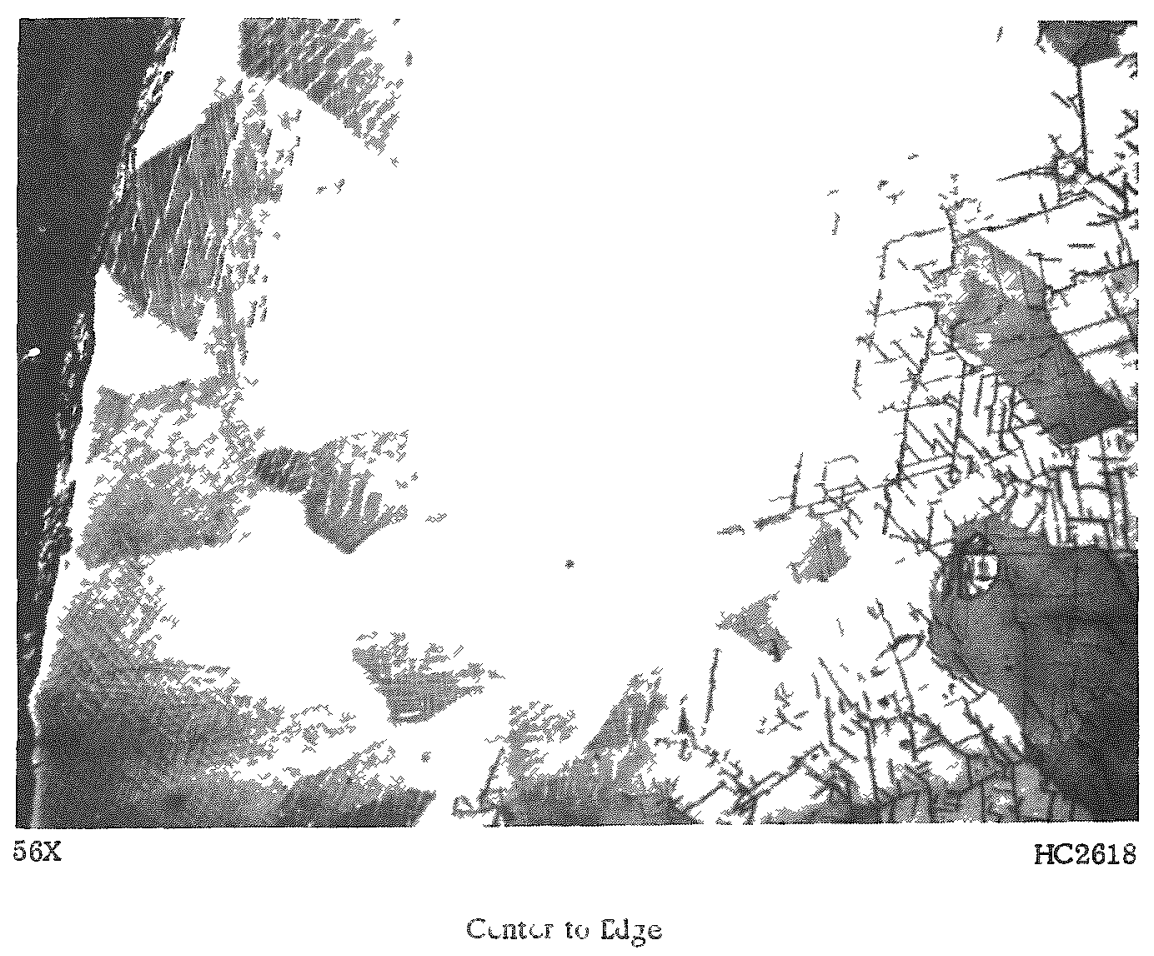

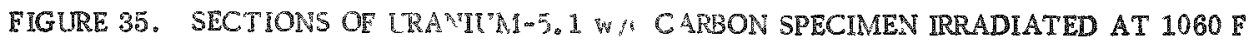
TO A BURNUP OF ABOUI 4 , $2 / 0$ OF TIIE URANIUM 


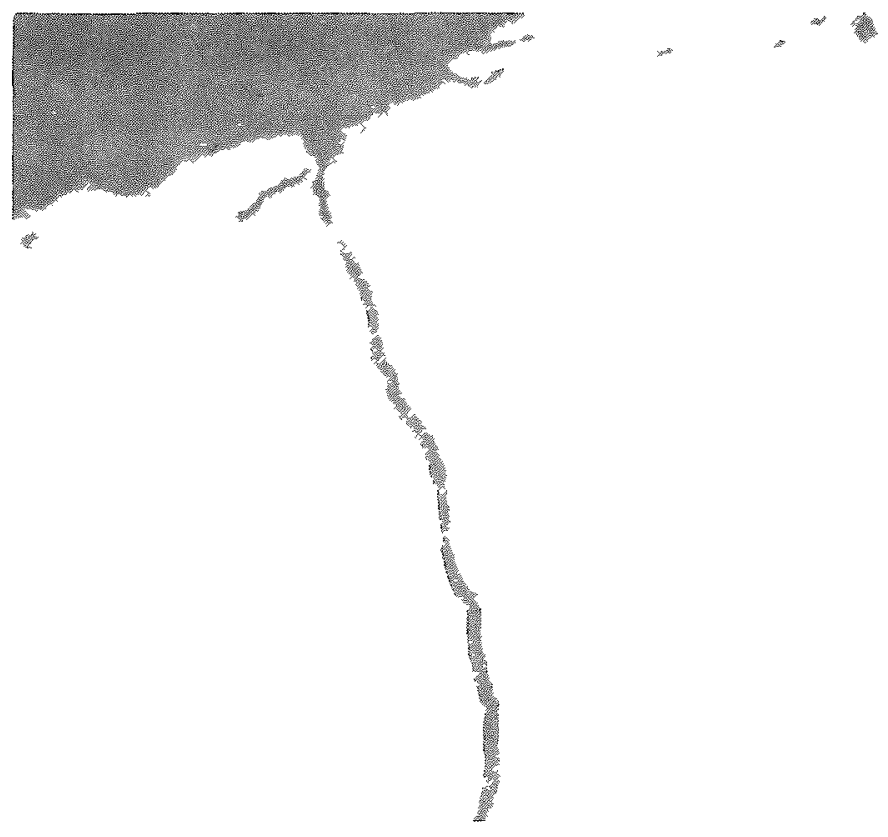

$270 \mathrm{X}$

HC2613

As Puldished

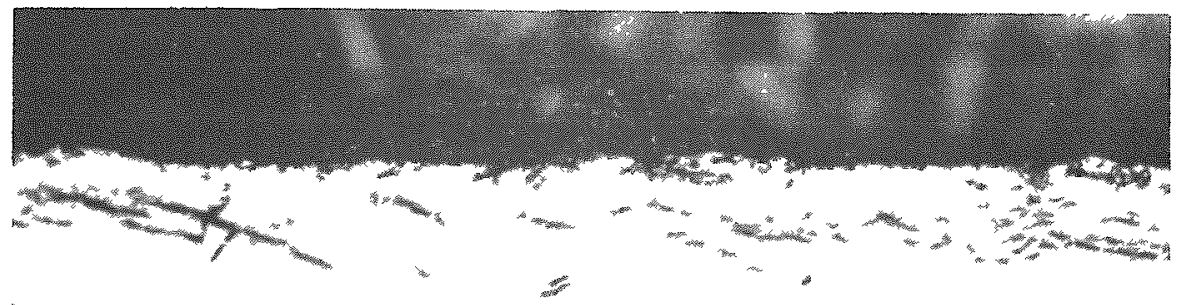

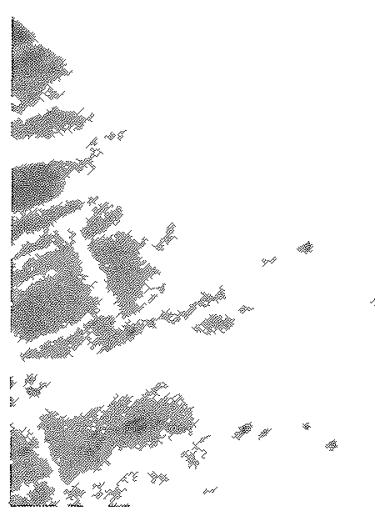

$270 x$

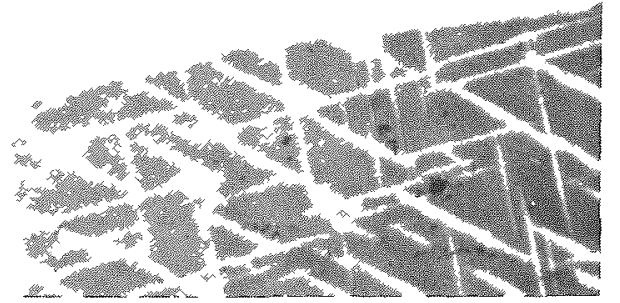

HC2615

As Etched

FIGURE 36. SURR ACE DAMAGE TO A URA NILM-5. 1 W CARUON SPECIMEN IRRADIATED AT A SURE ACE TEMPERATURE OF TUOE IN NaK CONI AINING TRACES OF OXYGEN 


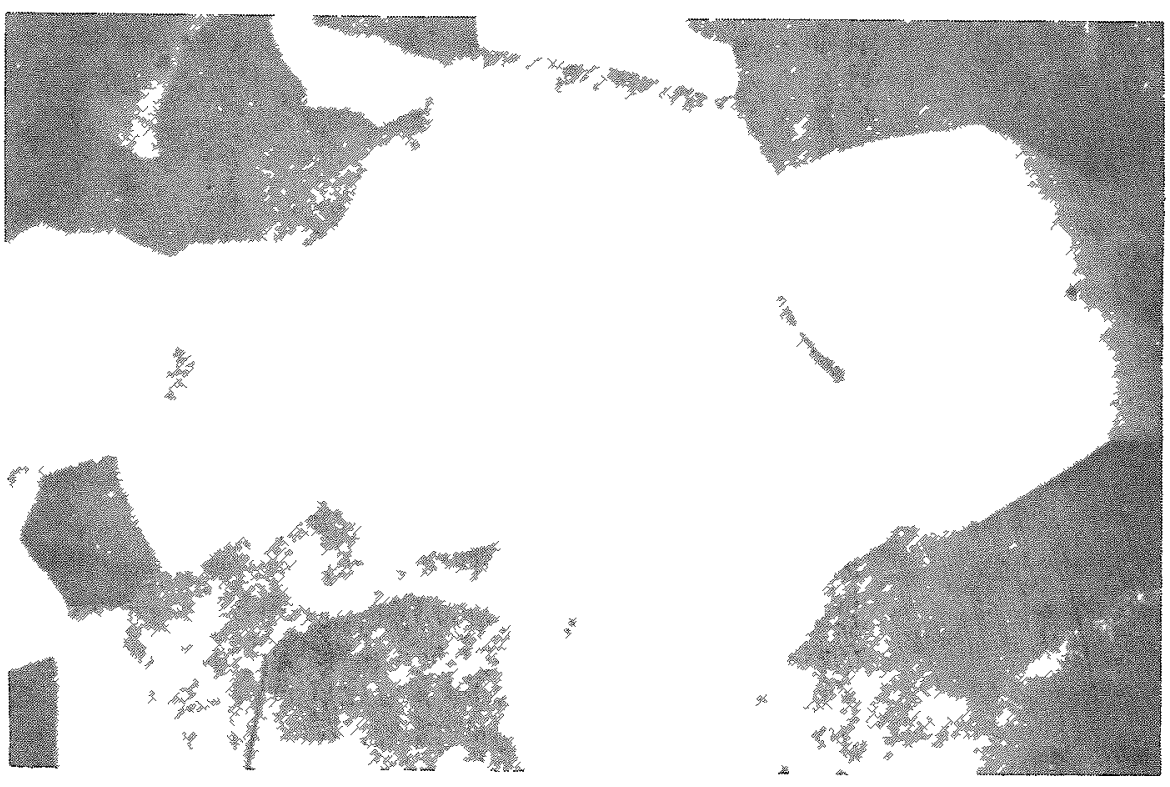

$100 \mathrm{x}$

HC 4190

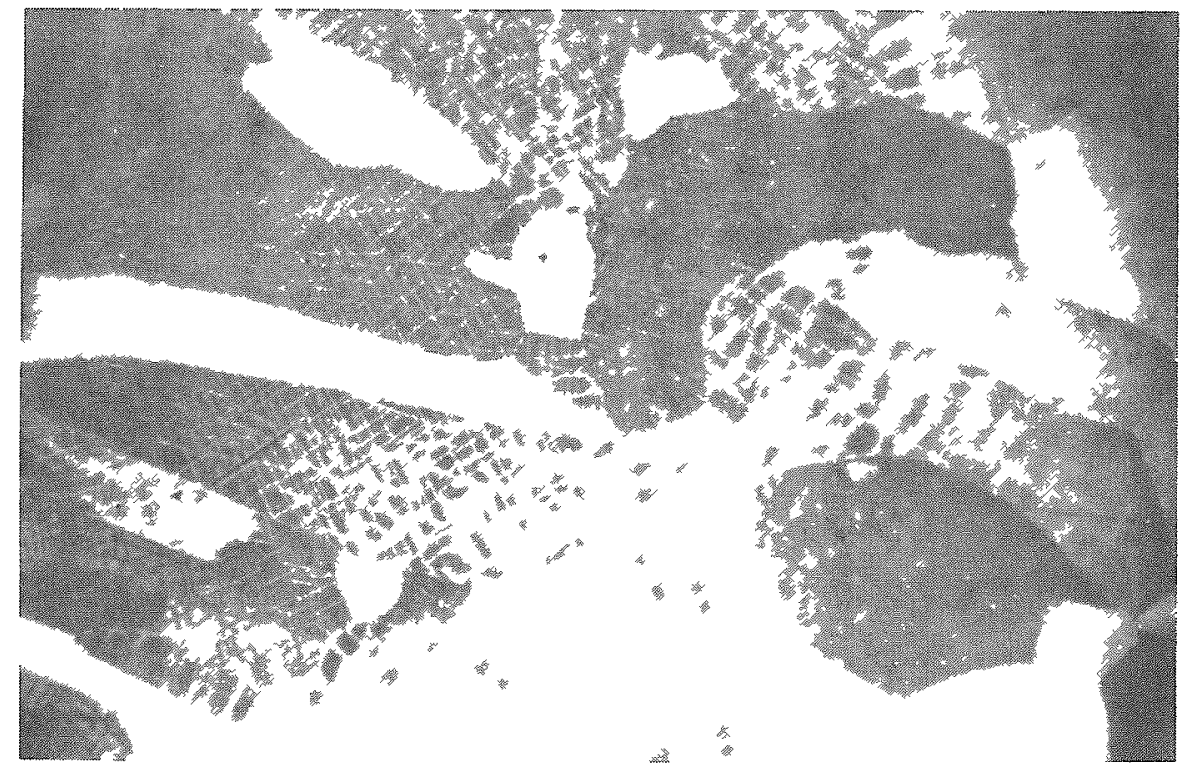

$100 \mathrm{X}$

HC 4189

FIGURE 37. SECTIONS OF URANIUM -5 W/O CARBON SPECIMEN, SHOWING ABSENCE OF UC2 AT CENTER (TOP) AND BEGINNING OF UC 2 DISAPPEARANCE NEAR SURF ACE (BOTTOM) AFTER IRRADIATION TO A BURNUP OF 1.7 a $/ 0$ OF THE URANUM AT ABOUT $1090 \mathrm{~F}$ 
are caused to disappear by carbn migration during ireadiation. Carbon migration might be induced by the presence of the temperature gradient in the specimens during irradiation or by the presence of carbon sinks such as stainless steel in the system. Still another possibility is that the fission fragments can produce enough disturbance of the structure by means of displacement spikes $(9,10)$ to, in effect, homogenize the structure in terms of carbon content. This supersaturated solution of carbon in uranium monocarbide apparently can be produced only as a result of irradiation. Its existence is supported by the apparent fuzziness of the $\mathrm{UC}_{2}$ platelets before they disappear entirely.

Although appreciable cracking and surface damage of UC during irradiation has been observed, fission-gas retention has been excellent. As shown in Table 25, the fission gas detected by sampling is approximately that expected to result from surface recoil. In general, cesium also was retained in the carbide, as evidenced by an analysis of the NaK in each of the capsules. In all cases, the cesium-137 detected in the NaK represented no more than 0.01 a/o burnup of the uranium.

The effective thermal conductivity of uranium carbide samples during irradiation has been estimated using the center and surface temperatures and heat-generation rates listed in Table 25. These estimates are possible because thermocouples were present in a drilled hole at the center of the top specimen and in the NaK near the surface of the same specimen. In each case, the effective conductivity remained about constant throughout the irradiation (or for the life of the thermocouples, if failure occurred), showing that no serious effects of irradiation were produced. In general, the effective conductivities were somewhat lower than the out-of-pile conductivities, but the probable error in such a crude measurement of conductivity is quite large. Thus, it is believed, as a result of the constancy of the effective conductivity in these tests, that no significant effect of irradiation upon the thermal conductivity has been encountered.

Sintered Uranium Carbide

Murray and Williams ${ }^{(11)}$ report that $2-\mathrm{mm}$-diameter pins of UC released 10 per cent of their contained fission gases during an irradiation to $3000 \mathrm{MWD} / \mathrm{T}$ at $630 \mathrm{C}$. It is indicated that the pins were of lower density than is normally achieved in sintering of $\mathrm{UO}_{2}$ and that cracking occurred during the irradiation. It is suggested that the low density "... may be in part responsible for the above gas release." Typical specimens of sintered UC such as those used in this study are stated to exhibit 15 per cent porosity.

\section{Evaluation and Discussion}

Cast uranium carbides of 4.6 to $5.2 \mathrm{w} / 0$ carbon have demonstrated excellent behavior at burnups of up to 1.7 a/o of the uranium at mean center temperatures of 880 to $1450 \mathrm{~F}$. These results were obtained at volume heat-generation rates comparable with those expected in sodium-cooled reactors. The principal problem encountered is cracking, although this has not been serious. Other more academic problems are surface damage due to oxygen in $\mathrm{NaK}$ and the disappearance of the $\mathrm{UC}_{2}$ second phase. The surface damage could be eliminated in practical sodium-bonded fuel elements, since only a small quantity of sodium would be in contact with the carbide. The disappearance of the $\mathrm{UC}_{2}$ has produced no practical problem, but further studies of the effects of composition and specimen environment upon the irradiation behavior of uranium carbides are desirable to define the reasons for this disappearance. 
Because of its brittle and nonmetallic nature, it seems likely that burnups of 5 to 10 a/0 of the uranium in UC will result in serious damage to bulk uranium carbides. However, the allowable limits of burnup and temperature for uranium carbides remain to be determined.

Sufficient data are not available to select the optimum composition of carbide for any given application, even in the range of 4.6 to $5.2 \mathrm{w} / 0$ carbon where results a re now available. While there are no irradiation data on $\mathrm{U}_{2} \mathrm{C}_{3}$ and $\mathrm{UC}_{2}$, as such, their lower densities suggest that there is little to recommend consideration of either as a fuel in bulk form for high-temperature use. Thus, compositions ranging near UC should continue to receive primary attention.

\section{References}

(1) Secrest, A. C., Foster, E. L., and Dickerson, R. F., "Preparation and Properties of Uranium Monocarbide Castings", BMI-1309 (January 2, 1959).

(2) Smith, C. A., and Rough, F.A., "Properties of Uranium Monocarbide", Nuclear Sci. and Eng., 6 (5), $391-95$ (November, 1959).

(3) Rough, F. A., Hare, A. W., Price, R. B., and Alfant, S., "Irradiation of Uranium Monocarbide", Nuclear Sci. and Eng., 7 (2), 111-21 (February, 1960).

(4) Price, R. B., Stahl, D., Stang, J.H., and Simons, E.M., "Irradiation-Capsule Study of Uranium Monocarbide", BMI-1425 (March 2, 1960).

(5) Peariman, H., "Irradiation of Uranium Carbide", Symposium on Effects of Irradiation on Fuel and Fuel Elements, AIME, October, 1959.

(6) Dayton, R. W., and Tipton, C. R., Jr., "Progress Relating to Civilian Applica-". tions During September, 1958 [through February, 1960]" BMI-1294, -1301, -1304, $-1307,-1315,-1324,-1330,-1340,-1346,-1357,-1366,-1377,-1381,-1391$, $-1398,-1403,-1409$, and -1423 .

(7) Hare, A. W., BMI, Unpublished Informatios.

(8) Rough, F. A., "An Evaluation of Data on Zirconium-Uranium Alloys", BMI-1030 (August, 1955).

(9) Brinkman, J.A., "The Production of Atomic Displacements by High-Energy Particles", NAA-SR-1459 (October, 1955).

(10) Bleiberg, M. L., Jones, L. J., and Lustman, B., "Phase Changes in Pile Irradiated Uranium-Base Alloys", WAPD-T-300 (May, 1956).

(11) Murray, P., and Williams, J., "Ceramic and Cermet Fuels", Proceedings of the Second United Nations International Conference on the Peaceful Uses of Atomic Energy, Geneva (1958), Vol 6, A/Conf. 15/P/318, pp 538-50. 